\title{
ESTUDOS SOROLÓGICOS SOBRE O FUNGO Hemileia vastatrix BERK. ET BR. E SOBRE SUA INTERAÇÃO COM PLANTAS DO GÊNERO COfFea
}

\author{
RICARDO HARAKAVA \\ Biólogo
}

Orientador: Dra. WALKYRIA BUENO DE CAMARGO MORAES

Dissertação apresentada à Escola
Superior de Agricultura "Luiz de
Queiroz", da Universidade de São
Paulo, para obtenção do título de
Mestre em Agronomia, A Área de
Concentração: Microbiologia Agricola

PIRACICABA

Estado de São Paulo - Brasil

Janeiro - 1993 
Harakava, Ficardo

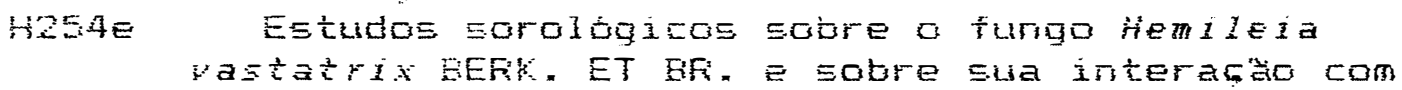

piantas du generc Corta. Piracicaba. 1995.

$75 \mathrm{pi}$.

Diss. (MEStre) - ESALQ

Bibliografia.

1. Anticorpo - Froducara 2. Ferpligen do caté - Controle F. Fungo fitopatodenica I. Escola Buberior de Agriculira Luiz de Gueiroz, Firacicaba

CDD 632.425 


\section{ESTUDOS SOROLÓGICOS SOBRE O FUNGO \\ Hemilaia varturix BERK. ET BR. E SOBRE SUA INTERAÇÃO \\ COM PLANTAS DO GENERO COffea}

RICARDO HARAKAVA

Aprovada em: 25.03. 1993

Comissão julgadora:

Prof. Dr. Darcy Martins da Silva

ESALQ/USP

Dr. Mario Barreto Figueiredo

Instituto Biológico - SP

Dra. Walkyria Bueno de Camargo Moraes

Instituto Biológico - SP

Profa. Dra. Walkyria Bueno de Camargo Moraes Orientadora 
for meus pais, dedico 


\section{AGRADECIMENTOS}

\section{Nossos sinceros agradecimentos}

À Dra. WALKYRIA BUENO DE CAMARGO MORAES, pela orientação, incentivo e confiança dispensados à realização deste trabalho.

Ao Dr. MÁRIO BARRETO FIGUEIREDO, pela revisão dos originais e sugestões na redação do texto.

Ao Dr. AlUÍSIO PAIVA DE CARVALHO ALBA, pela revisão dos originais e sugestões na redação do texto.

À ADELAIDE FERREIRA MARSIGLIO, colega de graduação e pós-graduação, pelo incentivo e companheirismo.

Ao Dr. HIROSHI KATAYAMA, pelo gentil fornecimento das galinhas poedeiras utilizadas no presente trabalho.

À Dra. VERA CECÍlIA A. FERREIRA, pelo auxílio na imunização das aves.

fotografias.

Ao DANIEL RYO SHINOZAKI, pelo auxilio na revelação das

Ao EDSON KUMASAKA, pelo auxilio na confecção dos gráficos e impressão dos originais.

À CAPES, pelo auxilio financeiro prestado.

Aos colegas da Seção de Bioquímica Fitopatológica do Instituto Biológico de São Paulo, pelo suporte técnico indispensável à realização deste trabalho.

deste trabalho.

A todos que, direta ou indiretamente, colaboraram para a realização 


\section{SUMÁRIO}

Página

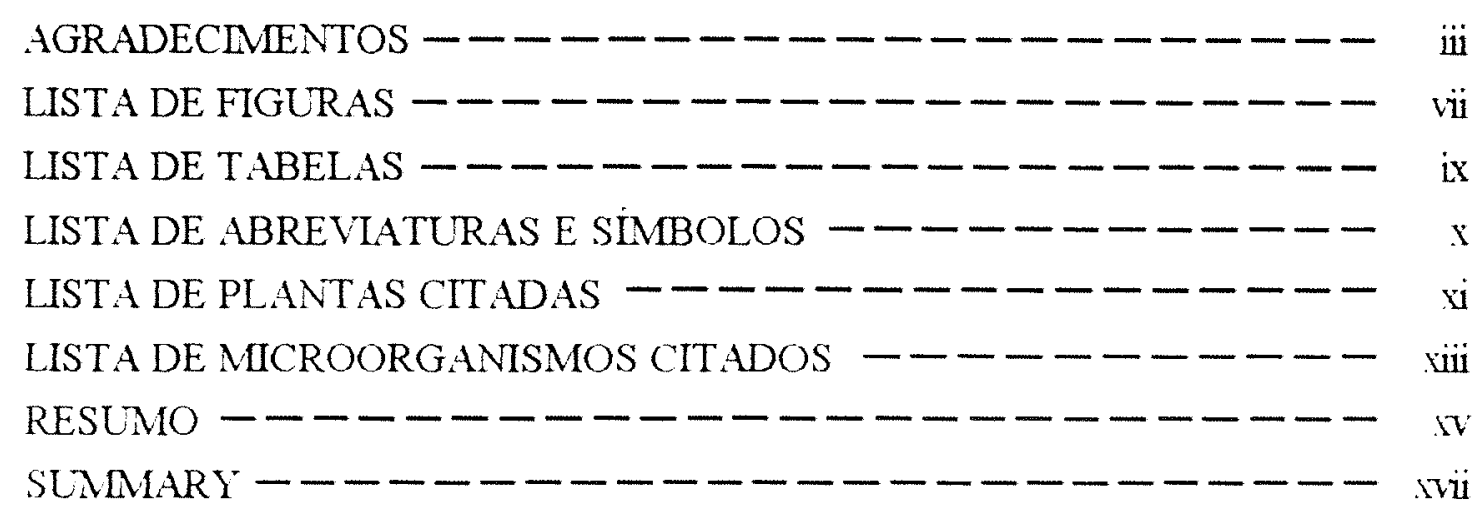

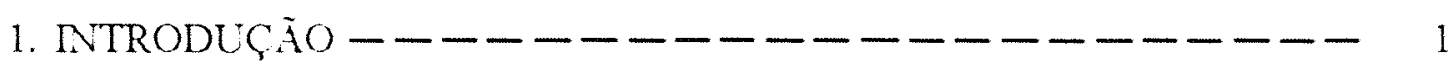

2. REVISÃO DE LITERATURA - - - - - - - - - - - - 4

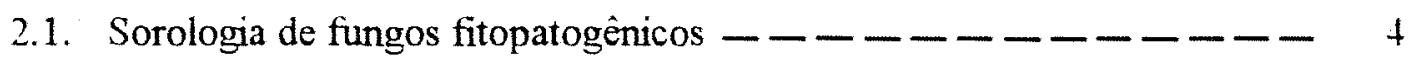

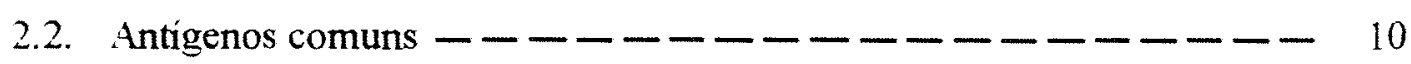

2.3. Metodologias empregadas para a obtenção de anticorpos - - - - - - - - - - - - - - - - -

2.4. Utilização de anticorpos extraídos de ovos de galinhas poedeiras - - - - - - - - - - - -

3. MATERIAL E MÉTODOS - - - - - - - - - - - - 26

3.1. Fonte de material - - - - - - - - - - - - - 26

3.1.1. Hemileia vastatrix - - - - - - - - ---26

3.1.2. Coffea spp. - - - - - - - - - - - $-\longrightarrow$

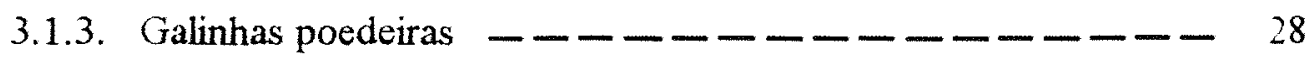

3.2. Extração dos antigenos - - - - - - - - 28

3.2.1. Hemileia vastatrix - - - - - - - - - -18

3.2.2. Coffea spp. - - - - - - - - - -28

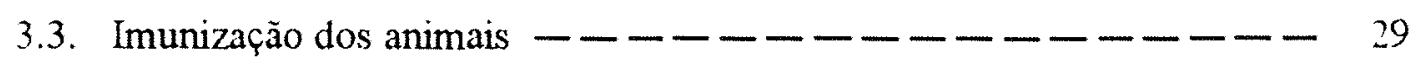

3.3.1. Com antigenos de urediniosporos de raças de $H$. vastatrix - - - - - - - - - - - - 
3.3.2. Com antigenos de urediniosporos de $H$. vastatrix coletados no campo - - - - - - - 29

3.3.3. Com antigenos de folhas de cafeeiro cv. Mundo Novo - - - - - - - - - - - - 30

3.4. Extração dos anticorpos a partir dos ovos - - - - - - - 30

3.5. Testes sorológicos - - - - - - - - - - ----72

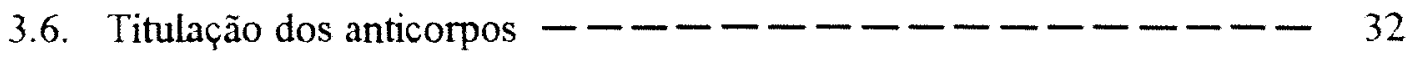

3.7. Absorção dos anticorpos - - - - - - - - 33

3.8. Quantificação dos antigenos comuns $-\longrightarrow--\longrightarrow-73$

3.9. Quantiticação de proteinas e carboidratos - - - - - - -34

3.10. Purificação dos antigenos comuns presentes no ex-

trato foliar de cafeeiro c. Mundo Novo - - - - - - -34

3.10.1. Precipitação etanólica - - - - - - - - - - 34

3.10.2. Cromatografia de troca iônica em DEAE Sephadex A-25 - - - - - - - - - - -75

3.10.3. Filtração em gel de Sephadex G-100 - - - - - 36 3.10.4. Avaliação da eficiência dos processos utilizados na purificação dos antígenos comuns - - - - - - - - - - - - -36

3.11. Estudos sobre a natureza quimica dos antígenos comuns - - - - - - - - - - - - $-\longrightarrow--17$

3.11.1. Tratamento com metaperiodato de sódio _ $-\ldots+\ldots$

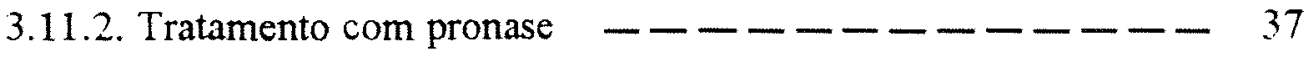

3.11.3. Tratamento térmico - $-\ldots-\ldots-\ldots-38$

4. RESULTADOS - - - - - - - - - - - - - - - 39

4.1. Titulação dos anticorpos produzidos pela galinha $\mathrm{A}---39$

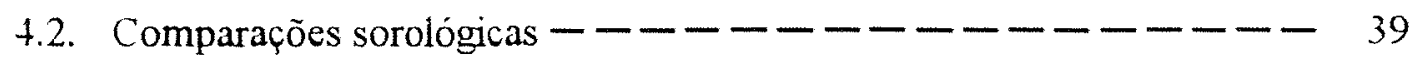

4.2.1. Anticorpos para antigenos de raças de H. vastatrix - - - - - - - - - - - - - - -

4.2.2. Anticorpos para antigenos de $H$. vastatrix coletada no campo - - - - - - - - - - - -

4.2.3. Anticorpos para antigenos de cafeeiro $\mathrm{cv}$.

Mundo Novo - - - - - - - - - - - - - 
4.3. Purificação dos antígenos comuns presentes no ex-

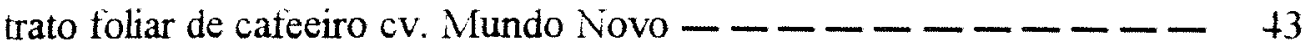

4.3.1. Precipitação etanólica - - - - - - - - - 43

4.3.2. Cromatografia de troca iônica em DEAE Sepha-

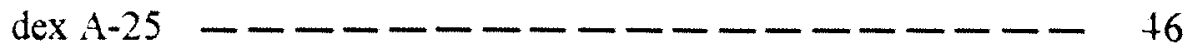

4.3.3. Filtração em gel de Sephadex G-100 - - - - - 49

4.3.4. Comparação das frações provenientes do extrato de cafeeiro cv. Mundo Novo quanto ao grau de pu-

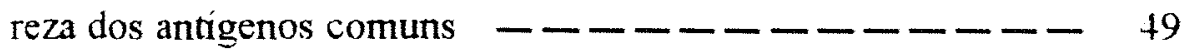

4.4. Estudos sobre a natureza quimica dos antigenos comuns - $-1-54$

4.4.1. Tratamento com metaperiodato de sódio _- - - - 54

4.4.2. Tratamento com pronase -----------54

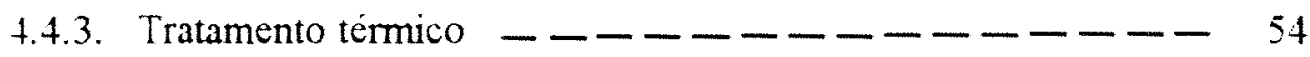

5. DISCUSSÃO - - - - - - - - - - - - - - - 55

5.1. Produção de anticorpos por galinhas poedeiras _- - - - - 55

5.2. Comparações sorológicas entre raças de $H$. vastatrix - - - - - 56

5.3. Antigenos comuns: detecçăo, purificaçào e natureza quimica - - - - - - - - - - - - - - - 58

6. CONCLUSÕES - - - - - - - - - - - ----1

REFERÊNCIAS BIBLIOGRÁFICAS- - - - - - - - 66 


\section{LISTA DE FIGURAS}

FIGURAS

Página

1 - Método de extração de anticorpos a partir das gemas de ovos - - - - - - - - - - - - - - - -

2. Avaliação do título dos anticorpos produzidos pela galinha A - - -

3- Reação sorológica em ágar contendo $\mathrm{NaCl}$ à concentração

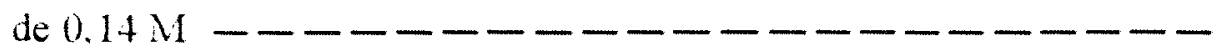

4 - Comparação sorológica entre raças II e III de $H$. vastatrix

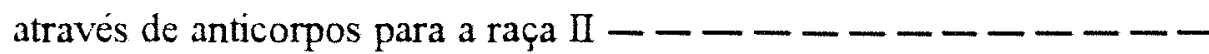

5 - Comparação sorológica entre raças II e III de $H$. vastatrix através de anticorpos para a raça III - - - - - - - - -

6- Reação dos anticorpos para $H$. vastatrix coletada no campo com antigeno homólogo e com antigeno de cafeeiro $\mathrm{cv}$.

Mundo Novo - - - - - - - - - - - -

7 - Deteç̧ăo de antigenos comuns à $H$. vastatrix em diversas espécies de cafeeiro - - - - - - - - ------14

8 - Reação dos anticorpos para cafeeiro cv. Mundo Novo com antigeno homólogo e com antígeno de $H$. vastatrix coletada no campo - - - - - - - - - - - - -

9 - Cromatografia de troca iònica da fração MN-Sd80 em coluna de DEAE Sephadex A-25 - - - - - - - - - - -

10 - Quantificação dos antigenos comuns presentes nas frações eluidas da coluna de DEAE Sephadex A-25 - - - - - - - 
11 - Determinação experimental dús volumes extemo (Vo) e interno (Vi) eluidos da coluna de Sephadex $\mathrm{G}-100-\ldots+\ldots$

12 - Filtração da fração MN-TI em coluna de gei de Sephadex G-100-- - - - - - - - - - - - - - - 51

13 - Quantificação dos antígenos comuns presentes nas frações eluídas da coluna de Sephadex $\mathrm{G}-100-\ldots-\ldots-\ldots-\ldots-52$ 


\section{LISTA DE TABELAS}

TABELAS

Página

1- Interações nas quais foram detectados antigenos comuns

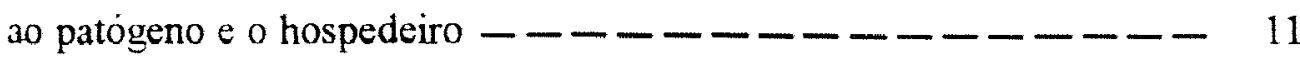

2 - Concentrações de proteinas e carboidratos do sobrenadante e sedimento provenientes da precipitação etanólica do

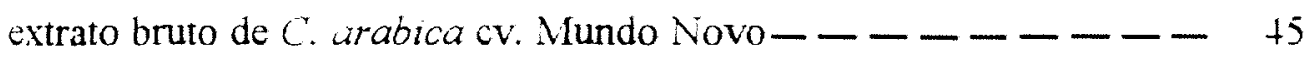

3- Comparação do grau de pureza dos antigenos comuns presentes nas frações provenientes do extrato bruto de $C$. arabica cv. Mundo Novo - - - - - $-1-7-\ldots$ 


\section{LISTA DE ABREVIATURAS}

Ac- - - - - - - - - - - - - - - - - - - anticorpo

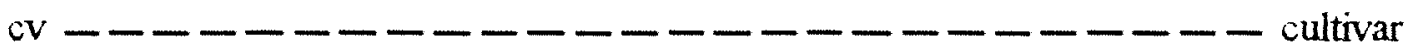

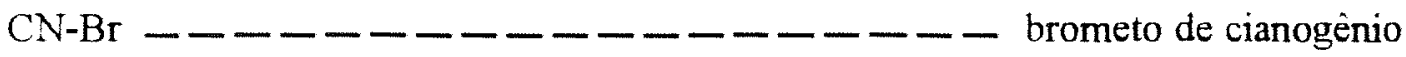
$\mathrm{DEAE}-\ldots-\ldots-\ldots-\ldots-\ldots-\ldots-\ldots$ dietilaminoetil EPS - - - - - - - - - - - - - - - - - $\mathrm{Eq}-\ldots-\ldots-\ldots-\ldots-\ldots-\ldots-\ldots$ equivalente

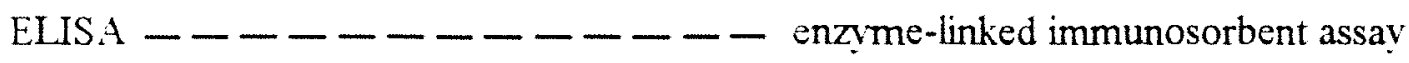

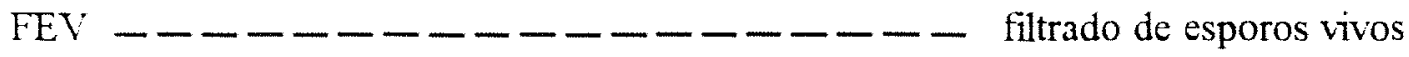

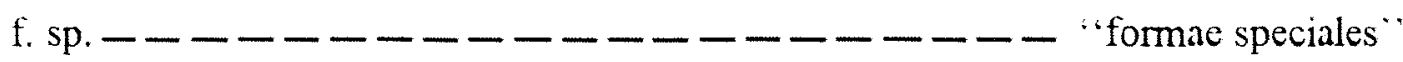

g - - - - - - - - - - - - - - gravidade

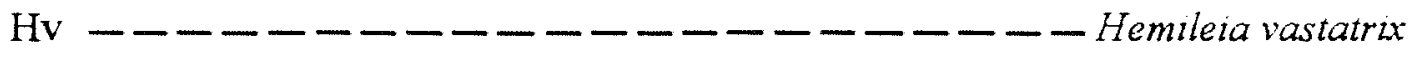
Ig - - - - - - - - - - - - - - $-\ldots$ imunoglobulina LPS - - - - - - - - - - - - - - - - MN-EB - _ - _ - extrato bruto de folhas de cafeeiro cv. Mundo Novo MN-GF - - - fração do extrato de folhas de cafeeiro cv. Mundo Novo proveniente da filtração em gel

$\mathrm{MN}-\mathrm{Sd} 80$ - - - sedimento proveniente da precipitação etanólica a $80 \%$ (v/V) a partir de extrato de folhas de cafeeiro cv.Mundo Novo

MN-Sn80 - - - sobrenadante proveniente da precipitação etanólica a $80 \%$ (V/ v) a partir de extrato de folhas de cafeeiro cv. Mundo Novo MN-TI - - - fração do extrato de folhas de cafeeiro cv. Mundo Novo proveniente da cromatografia de troca iônica

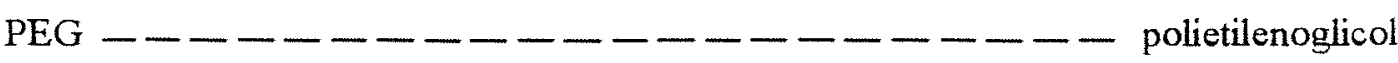

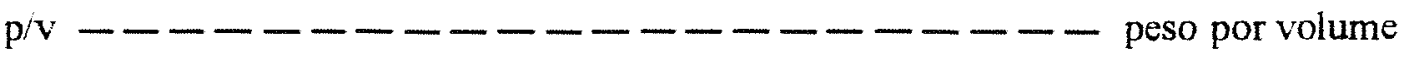
PVP - - - - - - - - - - - - - - - polivinilpirrolidona

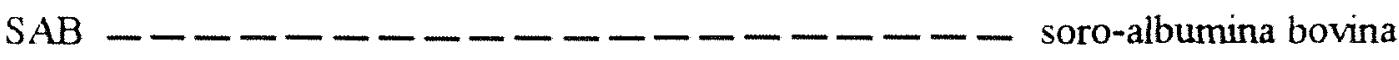

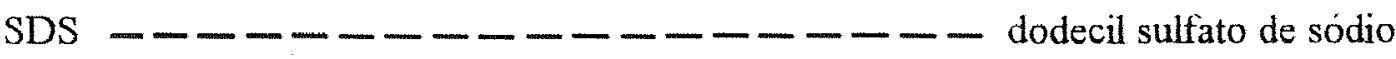
TF - - - - - - - - - - - - - - tampão fosfato de sódio TFS - - - - - - - - tampão fosfato de sódio adicionado de $\mathrm{NaCl}$ 
Tris - - - - - - - - - - TYMV - - - turnip yellow mosaic virus (virus do mosaico amarelo do nabo) Vi - - - - - - - - - - - - - - - - volume interno Vo - - - - - - - - - - - - - - -- volume externo 


\section{LISTA DE PLANTAS CITADAS}

NOME CIENTÍFICO

Allium cepa L.

Ananas sativus Schult.

Avena sativa L.

Brassica oleracea L. var. Botrytis-cauliflora

Cicer arietinum L.

Citrullus vulgaris Shrad.

Coffea arabica $\mathrm{L}$.

Coffea canephora Pierre

Coffea congensis Froehner

Coffea eugenioides Moore

Coffea liberica Hiern

Cucumis sativus $\mathrm{L}$.

Cucurbita pepo L.

Daucus carota L.

Fragaria vesca L.

Glycine max (L.) Merrill

Gassyptum arboreum L.

Gossypium hirsutum L.

Hordeum vulgare L.

Linum usitatissimum L.

Lycopersicum esculentum Mill.

Mangifera indica L.

Nicotiana tabacum L.

Oryza satriva L.

Pelargonium zonale L'Her, ex Soland in Ait.

Perilla frutescens (L.) Britt.

Phaseolus aureus Roxb.

Phaseolus vulgaris $L$.

Pisum sativum L.

Raphanus sativus L.

Secale cereale L.
NOME POPULAR

cebola

abacaxi

aveia

couve-flor

grão-de-bico

melancia

cafeeiro

cafeeiro

cafeeiro

cafeeiro

cafeciro

pepino

abóbora

cenoura

morango

soja

algodociro

algodoeiro

cevada

linho

tomateiro

mangueira

fumo

arroz

gerânio

perila

mungo

feijão

ervilha

nabo

centeio 
xiii

Solanum tuberosum L.

batata

Sorghum bicolor (L.) Moench

sorgo

Trifolium repens $\mathrm{L}$.

trêvo

Triticum aestivum L.

trigo

Zea mays L.

milho 


\section{LISTA DE MICROORGANISMOS CITADOS}

Accrocylindrium oryzae Sawada

Agrobacterium tumefaciens (Smith et Townsend) Conn

Ascochyta phaseolorum Sacc.

Botrytis allii Munn.

Botrytis cinerea Pers.

Botrytis squamasa Walker

Ceratocystis fimbriata Ell. et Halst.

Colletotrichum corchori Ikata et Tanaka

Colletotrichum gloeasporioides Penz.

Colletotrichum gloeosporioides f. sp. cucurbitae (Berk. et Mont.) n. comb.

Colletotrichum graminicola (Ces.) Wils.

Erysiphe graminis DC. f. sp. hordei Em. Marchal

Escherichia coli (Migula) Castellani et Chalmers

Fusarium caeruleum Lib. ex Sacc.

Fusarium moniliforme Sheldon

Fusarium moniliforme var. subglutinans Wollenw. et Reinking

Fusarium oxysporum Schlecht.

Fusarium axysporum f. sp. lupini (Linf.) Snyder et Hansen

Fusarium cxysporum f. sp. lycopersici (Sacc.) Snyder et Hansen

Fusarium axysporum f. sp. pisi (Linf.) Snyder et Hansen

Fusarium cxysporum f. sp. vasinfectum (Atk.) Snyder et Hansen

Fusarium semitectum Berk. et Rav.

Fusarium solani (Mart.) Sacc.

Fusarium solani f. sp. phaseoli (Burk.) Snyder et Hansen

Hemileia coffeicola Maubl. et Rog.

Hemileia vastatrix Berkeley et Brome

Macrophomina phaseolina (Tassi) Goid

Melampsora lini (Pers.) Lev.

Ophiobolus graminis (Sacc.) Sacc.

Phytophthora capsici Leomian.

Phytophthora cinnamomi Rands.

Phytophthora fragariae Hickman 
Phytophthora infestans (Mont.) de Bary

Phytophthora megasperma Drech. f. sp. glycinea (Hildeb.) Kuan

Pseudomonas phaseolicola (Burk.) Dowson

Puccinia graminis Pers. f. sp. tritici Eriks. et E. Henn.

Puccinia psidii Wint.

Puccinia sorghi Schw.

Pythium aphanidermatum (Eds.) Fitzp.

Rhizobium leguminosarum (Frank) Frank

Rhizobium trifolii Dangeard

Ustilago maydis (DC.) Cda.

Verticillium albo-atrum Reinke et Berth

Verticillium dahliae Kleb.

Verticillium hemileiae Bouriquet (=Verticillium lecanii Zimm.)

Xanthomonas malvacearum (Smith) Dowson

Xanthomonas transiucens Bradbury 


\title{
ESTUDOS SOROLÓGICOS SOBRE O FUNGO Hemileia vastatrix BERK. ET BR. E SOBRE SUA INTERAÇÃO COM PLANTAS DO GENERO COffea
}

\author{
Autor: RICARDO HARAKAVA \\ Orientador: Dra. WALKYRIA BUENO DE CAMARGO MORAES
}

\section{RESUMO}

A utilização de galinhas poedeiras para a produção de anticorpos a serem empregados em testes sorológicos foi avaliada. Esses animais mostraram-se de fácil manejo, tanto quanto aos cuidados diários quanto para a injeção dos antígenos. A metodologia de POLSON et alii (1985), para a extração dos anticorpos presentes nas gemas dos ovos, foi empregada com sucesso, sendo acessivel a qualquer laboratório que disponha de centrifuga que desenvolva entre 8.000 a $12.000 \mathrm{~g}$ de preferência, que comporte tubos com capacidade acima de $40 \mathrm{ml}$. O emprego dessa metodologia, além de tornar desnecessárias as sangrias, resulta em grande quantidade de anticorpos e, como os ovos podem ser conservados em geladeira, é possível a extração dos anticorpos de vários destes simultaneamente.

A produção de anticorpos por uma galinha imunizada com antígenos extrádos de urediniosporos da raça II de $H$. vastatrix, foi acompanhada por 53 dias após a última injeção. Foi verificado título máximo $(1: 32)$ nos ovos postos entre os $18^{\circ}$ e $41^{\circ}$ dias após a última injeção.

Anticorpos produzidos para antígenos extraidos de urediniosporos das raças II e III de $H$. vastatrix, respectivamente, não apresentaram especificidade para raça, reagindo igualmente com antígenos homólogos e heterólogos e perdendo completamente a capacidade de reagir com antígeno homólogo, após absorção com antígeno heterólogo.

As linhas de precipitação formadas em teste de dupla difusão foram mais intensas quando foi utilizado, para a preparação do gel de ágar, tampão adicionado de $\mathrm{NaCl}$ à concentração de $1,4 \mathrm{M}$ do que à $0,14 \mathrm{M}$.

Anticorpos produzidos por galinha imunizada com antígeno extraído de urediniosporos de $H$. vastatrix coletados no campo, apresentaram reação não só com o antígeno homólogo como também com antígenos extraidos de folhas de cafeeiros 
pertencentes às seguintes espécies: $C$. arabica cv. Mundo Novo, $C$. liberica, $C$. eugenioides, $C$. congensis, $C$. canephora cv. Kouillou e cv. Robusta e híbrido Sarchimor. A ocorrência de antígenos comuns ao fungo em todas as espécies de cafeeiros estudadas, sugere um envolvimento destes antígenos na compatibilidade básica existente entre $H$. vastatrix e plantas do gênero Coffea.

Anticorpos produzidos por galinha imunizada com antígeno extraído de folhas de cafeeiro cv. Mundo Novo, apresentaram reação somente com antígenos extraídos de cafeeiros, não detectando, portanto, antígenos comuns no extrato do fungo.

Extrato obtido a partir de folhas de cafeeiro cv. Mundo Novo foi submetido, sequencialmente, a precipitação com etanol à concentração final de $80 \% \mathrm{v} / \mathrm{v}$, cromatografia de troca iônica em coluna de DEAE Sephadex A-25 e filtração em coluna de Sephadex G-100. Os antígenos comuns foram detectados somente no precipitado etanólico, apresentaram afinidade pelo trocador aniônico e foram ehúdos principalmente no volume externo da coluna de Sephadex G-100. O comportamento destes antígenos na cromatografia de troca iônica e na filtração em gel, mostrou uma heterogeneidade tanto quanto ao grau de afinidade pelo trocador aniônico quanto à dimensão de suas moléculas.

A correspondência entre a eluição das proteínas com a dos antígenos comuns, tanto na cromatografia de troca iônica quanto na filtração em gel, indicou uma natureza proteica para essas moléculas, porém, a resistência à fervura em banho-maria por $60 \mathrm{~min}$ ou ao tratamento com pronase indicou uma natureza polissacarídica para 0 epitopo ao qual os anticorpos se ligam. Portanto, os antígenos comuns poderiam tratar-se de gicoproteínas, nas quais predomina a porção proteica mas cujos sítios antigênicos residiriam nas ramificações polissacarídicas. 
xviii

\title{
SEROLOGLAL STUDIES ON THE FUNGUS Hemileia vastatrix BERK. ET BR. AND ON ITS INTERACTION WITH PLANTS OF THE GENUS Coffea
}

\author{
Author: RICARDO HARAKAVA \\ Adviser : Dr. WALKYRIA BUENO DE CAMARGO MORAES
}

\section{SUMMARY}

The utilization of laying hens for the production of antibodies to be employed in serological tests has been analysed. These animals have shown easy handling, for both the daity care and the injection of the antigens. The methodology of POLSON et alii (1985), for the extraction of the antibodies present in the eggs' yolks, was successfully employed, being accessible for any laboratory that has a centrifuge that develops between 8,000 to $12,000 \mathrm{~g}$, preferentially one that bears tubes with capacity above $40 \mathrm{ml}$. The utilization of this methodology, besides rendering the bleedings unnecessary, results in lange ammounts of antibodies and, as the eggs can be kept in refrigerator, it is possible to extract the antibodies from many of them simultaneously.

The production of antibodies by a hen immunized against antigens extracted from urediniospores of the race II of $H$. vastatrix, was verified for 53 days after the last injection. The maximum titer $(1: 32)$ was verified for eggs layed between the 18 th and 41 st days after the last injection.

Antibodies produced against antigens extracted from urediniospores of the races II and III of $H$. vastatrix, respectively, did not show race specificity, reacting equally with homologous and heterologous antigens and loosing completely the capacity of reacting with homologous antigen after absorption with heterologous one.

Precipitation lines were more intense when the agar gel was prepared with buffer containing $1.4 \mathrm{M} \mathrm{NaCl}$ as compared with those in which $0.14 \mathrm{M}$ was added.

Antibodies produced by a hen immunized against antigen extracted from urediniospores of $H$. vastatrix collected in the field, have shown reaction with both homologous antigen and antigens extracted from leaves of coffee plants of the following species: $C$. arabica cv. Mundo Novo, C. liberica, C. eugenioides, C. congensis, $C$. canephora cv. Kouillou and cv. Robusta and Sarchimor hibrid. The occurrence of common antigens between the fungus and all the species of coffee plants studied, 
suggests an involvement of these antigens in the basic compatibility between $H$. vastatrix and plants of the genus Coffea.

Antibodies produced by a hen immunized against antigen extracted from leaves of $C$. arabica $\mathrm{cv}$. Mundo Novo, have shown reaction only with antigens extracted from coffee plants, and did not detect common antigens in the fungus extract.

Extract obtained from leaves of $C$. arabica $\mathrm{cv}$. Mundo Novo was submitted, sequentially, to the precipitation with ethanol at a final concentration of $80 \%$ $\mathrm{v} / \mathrm{v}$, ion exchange chromatography in a column of DEAE Sephadex A-25 and gel filtration in a column of Sephadex G-100. Common antigens were detected onty in the ethanolic precipitate, showed affinity for the ion exchanger and were eluted mainly in the void volume of the Sephadex G-100 column. The behaviour of these antigens in the ion exchange chromatography and in the gel filtration, showed to be heterogeneous in relation to both the affinity for the ion exchanger and the size of their molecules.

The correspondence between the elution of proteins and of common antigens in the ion exchange chromatography and in the gel filtration, suggests a protein nature for these molecules, but the maintenance of the serological reactivity even after heating in boiling water for $60 \mathrm{~min}$ or after pronase treatment, suggests a polysaccharide nature for the epitope to which the antibodies bind. Therefore, the common antigens seem to be complex protein-polysaccharide macromolecules in which the antigenic sites are located in the polysaccharide moiety. 


\section{INTRODUÇÃO}

A ferrugem alaranjada do cafeeiro (Coffea arabica L.) tem como agente causal o fungo Hemileia vastatrix Berkeley et Brome, pertencente a classe Basidiomycetes, ordem Uredinales e familia Pucciniaceae. Outra espécie do mesmo gênero, Hemileia coffeicola Maubl. et Rog. é também causadora de ferrugem no cafeeiro, porém ainda não detectada no Brasil.

A ferrugem do cafeeiro foi observada pela primeira vez em 1861 na região do lago Vitória em Nyanza, na África Oriental e em 1869 foi relatado como causadora de danos econômicos no Ceilão (atual Sri Lanka) (BERKELEY, 1869). Atualmente essa doença está presente em países da África, Ásia, Oceania e Américas do Sul e Central. No hemisfério ocidental, a ferrugem foi detectada pela primeira vez no Brasil, em 1970, no Estado da Bahia e, apresentando rápida disseminação, atinge atualmente todas as regiões produtoras de café no pais, além de outros países latinoamericanos (CARDOSO et alii, 1986).

A quebra média na produção causada pela doença é estimada entre 20 e $30 \%$ em lavouras não tratadas ou tratadas incorretamente (IBC, 1985). Em termos mundiais, as perdas econômicas são estimadas entre 1 e 2 bilhões de dólares anuais, constituindo-se desta forma como uma dentre as 7 doenças ou pragas mais importantes das culturas tropicais (KUSHALAPPA \& ESKES, 1989).

São conhecidas 31 raças fisiológicas de $H$. vastatrix, das quais 12 já detectadas no Brasil (CARDOSO et alii, 1986). A raça II, portadora do gene de virulência v5, é a predominante e ataca os cultivares de café portadores somente do gene de resistência SH5 (Mundo Novo, Catuai, Caturra, Bourbon, Harar), que constituem a maioria nos cafezais brasileiros.

A identificação destas raças tem sido realizada através da inoculação de urediniosporos em clones diferenciadores de café. Esta metodologia necessita de 30 a 40 dias para que os sintomas possam ser observados, e também 17 clones de diferentes grupos fisiológicos de cafeeiro (CARDOSO et alii, 1986). Metodologia empregando 
discos de folhas, ao invés da planta inteira, tem sido utilizada com sucesso (CARDOSO et alii, 1986; ESKES, 1983).

Métodos sorológicos são apontados como capazes de distinguir grupos taxonômicos de fungos aos níveis de gênero, espécie, "formae speciales"e até mesmo de raça (FIGUEIREDO et alii, 1977).

Nos trabalhos de sorologia de fungos fitopatogênicos o animal mais utilizado para a produção dos anticorpos tem sido o coelho. Dentre as características favoráveis apresentadas por este animal, destacam-se a produção de grande quantidade de anticorpos circulantes que permite sangrias diárias de até $10 \mathrm{ml}$, fácil criação e manejo, alimentação pouco dispendiosa e necessidade de pouco espaço físico (FIGUEIREDO et aii, 1977).

Galinhas são também animais de fácil criação e manejo, porém menos utilizadas devido à pequena quantidade de sangue que pode ser extraido após as imưnizações. Esta limitação está sendo contornada com o emprego da técnica de extração de anticorpos a partir das gemas dos ovos postos por galinhas imunizadas. Utilizando-se galinhas poedeiras, é possivel obter anticorpos que seriam equivalentes aos oriundos de sangrias diárias, sem injuriar o animal.

Já foram descritas diversas técnicas de purificação dos anticorpos a partir da gema, desde processos refinados de cromatografia até métodos mais simples de precipitação, os quais chegam a diferentes graus de pureza dos anticorpos (POLSON et alii, 1980; POLSON et alii, 1985; HASSL \& ASPOCK, 1988; VIEIRA et alii, 1984; BADE \& STEGEMANN, 1984; JENSENIUS et alii, 1981).

Esses animais têm sido utilizados principalmente em pesquisas médicas e no desenvolvimento de radioimunoensaios para hormônios (CARROLL \& STOLLAR, 1983; SONG et alii, 1985; VIEIRA et alii, 1984). Na patologia vegetal, relatos de sua utilização restringem-se à produção de anticorpos para teste imunoenzimático (ELISA) de detecção dos vírus da tristeza dos citros e do mosaico do fumo (BAR-JOSEPH \& MALKINSON, 1980).

A utilização de métodos sorológicos tem revelado a existência de antígenos comuns a patógenos e plantas em diversas interações estudadas. Esses antígenos são encontrados, geralmente, entre patógenos e suas respectivas plantas hospedeiras, o que suscita a possibilidade destas moléculas estarem envolvidas no mecanismo de reconhecimento entre ambos.

Antígenos comuns a $H$. vastatrix e C. arabica foram detectados por 
ALBA et alii (1983). Os autores observaram que em combinação compatível do fungo com o hospedeiro existia menor disparidade antigênica que em combinação incompatível.

Apesar de já terem sido detectados em inúmeras interações patógeno-planta, há uma carência de trabalhos mais aprofundados sobre os antígenos comuns. A purificação e caracterização destas moléculas é um pré-requisito para que o papel por elas desempenhado no mecanismo de reconhecimento possa ser elucidado.

Diante do exposto, são objetivos do presente trabalho:

- verificar a praticidade da utilização de galinhas poedeiras e do método de POLSON et alii (1985) para a obtenção de anticorpos a serem empregados em testes sorológicos, - obter anticorpos para diferentes raças de $H$. vastatrix e verificar a especificidade destes, - verificar a ocorrência de antígenos comuns a $H$. vastatrix e plantas do gênero Coffea, através de anticorpos produzidos por galinhas imunizadas com antígenos extraídos do fungo ou do hospedeiro,

- purificar e obter subsídios para uma melhor caracterização das moléculas antigênicas comuns a $H$. vastatrix e cafeeiro. 


\section{REVISÃO DE LITERATURA}

\subsection{SOROLOGIA DE FUNGOS FITOPATOGÊNICOS}

A sorologia vem sendo utilizada desde primórdios deste século, principalmente na Medicina onde é aplicada tanto na diagnose quanto na terapêtica de doenças. Até há poucas décadas sua aplicação na Fitopatologia era pouco difundida, principalmente no caso dos fungos, pois as técnicas desenvolvidas pela Micologia Médica, para fungos leveduriformes, não se aplicavam aos fungos fitopatogênicos (FIGUEIREDO et alii, 1977).

Atualmente já existem metodologias adequadas ao estudo destes fungos e o número de trabalhos publicados sobre o assunto multiplicaram. As técnicas desenvolvidas na pesquisa médica estão sendo transferidas mais rapidamente aos estudos fitopatológicos, assim, trabalhos nos quais foram produzidos anticorpos monoclonais para antígenos de fungos fitopatogênicos já não não raros.

FIGUEIREDO et alii (1977) realizaram extensa revisão sobre os trabalhos de sorologia de fungos fitopatogênicos. Foi realizado um levantamento das técnicas utilizadas nas várias etapas dos métodos sorológicos, desde a extração dos antígenos até os tipos de testes sorológicos utilizados. A análise dos trabalhos levou os autores à conclusão que a sorologia apresenta utilidade não somente na sistemática, diferenciando espécies, "formae speciales" e raças fisiológicas, como também no fornecimento de dados para um melhor entendimento de fenômenos relacionados à interação patógeno-hospedeiro.

A capacidade discriminatória dos testes sorológicos pode ser exemplificada pelos vários trabalhos realizados sobre o gênero Fusarium.

MADHOSNGH (1964) comenta em seu trabalho as dificuldades da taxonomia no gênero Fusarium, quando baseada somente em características morfológicas dos fungos. Através de testes sorológicos de dupla difusão difusão em ágar (teste de Ouchteriony), verificou a existência de antigenos comuns às espécies Fusarium 
axysporum Schlecht., Fusarium moniliforme Sheldon e Fusarium solani (Mart.) Sacc. assim como antígenos especificos, permitindo, desta forma, distingui-los sorologicamente. Foi verificada também uma maior proximidade entre $F$. axysporum e $F$. moniliforme que entre estes e $F$. solani, o que estava de acordo com os dados de taxonomia morfológica.

TEMPEL (1957) inoculou coelhos com diferentes preparações antigênicas de raças e "formae speciales" de $F$. cxysporum. Não obteve sucesso na distinção entre estas através de microaglutinação e microprecipitina, porém, através de teste de dupla difusão em ágar, verificou alta especificidade para os anti-soros preparados com cultura líquida de $F$. oxysporum f. sp. pisi (Linf.) Snyder et Hansen e $F$. axysporum f. sp. lupini (Linf.) Snyder et Hansen.

HORNOK (1980) utilizou imunoeletroforese cruzada em tandem para comparar sorologicamente espécies de Fusarium pertencentes às seções Gibbosum e Discolor. Nesta técnica, os antígenos extraídos de dois fungos diferentes são colocados em poşos localizados próximos um ao outro na placa de gel de agarose e, ao ser aplicada a corrente elétrica, os antígenos migram com uma pequena defasagem entre si. Realizando-se a corrida na segunda dimensão, no gel contendo os anticorpos, os antígenos em comum presentes nas amostras formam arcos de precipitação que se fundem em suas extremidades enquanto que antígenos distintos formam arcos que se cruzam. Através do cálculo do índice de similaridade sorológica, que leva em consideração a quantidade de antígenos comuns as duas espécies diferentes de fungo, foram agrupadas as espécies mais semelhantes sorologicamente. Em alguns casos houve concordância com a classificação segundo dados morfológicos e em outros isto não ocorreu. O autor enfatiza que a sorologia é somente uma das formas de se caracterizar organismos e, portanto, seus dados devem ser encarados como uma contribuição à taxonomia.

Três linhagens de Fusarium oxysporum f. sp. vasinfectum (Atk.) Snyder et Hansen foram estudadas sorologicamente por KALYANASUNDARAM \& CHARUDATTAN (1969). Duas destas mostraram-se patogênicas a diferentes espécies de algodão (Gassypium arboreum L. a Gassypium hirsutum L.) e a terceira era nãopatogênica. Em teste de dupla difusão em ágar foi verificado maior número de linhas de precipitação em comum entre linhagens patogênicas do que entre estas e a linhagem nãopatogênica. Segundo os autores parece haver correlação entre a presença de certos antígenos e a patogenicidade de linhagens do fungo. 
MORTON \& DUKES (1966), procurando encontrar um método alternativo para a diferenciação das raças 1 e 2 de Fusarium axysporum $f$. sp. lycopersici (Sacc.) Snyder et Hansen, até então realizada através de inoculação em linhagens diferenciadoras de tomate, optaram pela sorologia devido a sua simplicidade e rapidez Utilizando micélio desintegrado por ultra-som como antígeno imunizante, conseguiram obter anti-soros que, após absorção com antígenos heterólogos, apresentavam especificidade para raça.

Diferenças entre as raças fisiológicas 2 e 3 de $F$. axysporum $\mathrm{f}$. sp. lupini foram detectadas por RATAJ-GURANOWSKA et alii (1984), através de imunoeletroforese cruzada e imunoeletroforese cruzada em tandem. Esta última permitiu que os autores verificassem que das 52 linhas de precipitação formadas em reação homóloga de anti-soro e antígeno da raça 3, 51 eram detectadas em reação heteróloga com antígenos da raça 2 . Os autores acreditam que esta diferença possa estar relacionada à diferença na virulência entre as duas raças.

Os primeiros trabalhos de sorologia de fungos fitopatogênicos no Brasil são de FIGUEIREDO et alii (1972) e FIGUEIREDO \& NAMEKATA (1974), que estudaram o fungo Ascochyta phaseolorum Sacc. Através de testes de aghutinação, precipitina e dupla difusão em ágar, e utilizando anti-soros absorvidos com antígenos heterólogos, puderam distinguir $A$. phaseolorum de outras espécies morfologicamente semelhantes. Os autores realizaram também estudos sobre a natureza química dos antígenos e os resultados indicaram a possibilidade de polissacarideos serem responsáveis pela antigenicidade específica. Foi verificado que os antígenos extraídos de esporos produziam anti-soros mais específicos do que antígenos extraídos de micélio, possivelmente por estruturas reprodutivas estarem sujeitas a menor variação quantitativa e qualitativa dos antígenos, do que estruturas somáticas.

Uma série de trabalhos de tese apresentados ao Departamento de Fitopatologia da Escola Superior de Agricultura "Luiz de Queiroz" da Universidade de São Paulo, exemplificam como a sorologia pode contribuir com dados adicionais aos estudos taxonômicos baseados na morfologia, patogenicidade, compatibilidade sexual, requerimentos nutricionais e espectro de hospedeiros (KIMATI, 1975; MENTEN, 1977; BAJUNGU, 1979; GERALDI, 1981; GHINI, 1984; IGARASHI, 1984; CENTURION, 1985).

KIMATI (1975), em seu estudo sobre isolados de fungos do gênero Colletotrichum de esporos falcados obtidos da cana-de-açúcar (Saccharum officinarum 
L.), do milho (Zea mays L.) e do sorgo (Sorghum bicolor (L.) Moench), verificou que estes podiam ser distinguidos através de auxanografia, especificidade de hospedeiros e, também, sorologicamente, dando apoio a designação de Colletotrichum graminicola "formae speciales" sacchari, zeae e sorghi, respectivamente.

MENTEN (1977) não detectou diferenças entre raças fisiológicas de Colletotrichum gloeosporioides f. sp. cucurbitae (Berk. et Mont.) n. comb. tanto por características culturais como morfológicas. Os dados de sorologia também não permitiram diferenciar as raças, porém o autor acredita que a utilização de técnicas sorológicas mais refinadas poderiam demonstrar diferenças antigênicas entre estas.

BAJUNGU (1979) verificou que isolados de Colletotrichum gloeoporioides Penz. da cebola (Allium cepa L.) e da manga (Mangifera indica L.) apresentavam especificidade de hospedeiro, além de diferenças nas taxas de crescimento. Esta distinção pôde ser confirmada pelos testes sorológicos, onde anti-soros reagiram somente com antígenos homólogos. Foi verificado, porém, que um dos isolados da cebola, embora patogenicamente indistinguivel dos demais, não apresentou homologia em nível sorológico. Os resultados obtidos suportam, segundo o autor, a designação de C. gloeosporioides "formae speciales" cepae para os isolados da cebola e que a validade da sorologia para a caracterização destes isolados precisa ser melhor estudada.

GERALDI (1981), complementando o trabalho de KMATI (1975) sobre o fungo C. graminicola, causador de antracnose em várias espécies de gramíneas, verificou que isolados do trigo (Triticum aestivum L.) eram também patogênicos a cultivares de centeio (Secale cereale L.) e cevada (Hordeum vulgare L.) mas não afetavam o milho, sorgo e aveia (Avena sativa L.). Os dados de sorologia evidenciaram que C. graminicola do trigo é distinto dos isolados da cana-de-açúcar (C. graminicola $\mathrm{f}$. sp. sacchari) e sorgo (C. graminicola f. sp. sorghi). Baseada nestes dados, a autora apóia a designação de "formae speciales" secalis para os isolados do trigo, centeio e cevada.

GHINI (1984) verificou a ocorrência dos fungos Botrytis squamosa Walker, Botrytis allii Munn. e Botrytis cinerea Pers. associados à queima das pontas e ao crestamento de inflorescências da cebola, em regiões produtoras dos Estados de São Paulo e Santa Catarina. As três espécies puderam ser distinguidas pela morfologia e pelo espectro de hospedeiros. Os dados de sorologia também deram indícios de tratarem-se de três espécies distintas, uma vez que o anti-soro produzido para $B$. allii reagiu somente com antígenos homólogos e o anti-soro para $B$. squamosa, apesar de apresentar reações 
com antígenos heterólogos, mostrou também a ocorrência de um antígeno específico.

IGARASHI (1984) ao estudar 33 isolados de Colletotrichum spp. de diferentes cultivares de morango (Fragaria vesca L.) e de diferentes regiões do Estado de São Paulo, verificou a ocorrência de resistência ao fungicida Benomil em 27 destes. Estudos comparativos de morfologia e patogenicidade entre os isolados resistentes e sensíveis, demonstraram a ocorrência de diferenças significativas que puderam ser confirmadas pelos estudos sorológicos.

CENTURION (1985) não obteve sucesso na distinção sorológica entre isolados de $F$. moniliforme do arroz (Oryza sativa L.), milho, cana-de-açúcar e sorgo, assim como entre isolados de Fusarium moniliforme var. subglutinans Wollenw. et Reinking da cana-de-açúcar e abacaxi (Ananas sativus Schult.). Distinção entre os dois fungos também não foi possivel. Estes resuitados poderiam ser explicados, segundo a autora, pela não adequação da metodologia utilizada ou pelo fato destes fungos serem realmente indistinguiveis sorologicamente.

Nesta série de trabalhos acima descritos (KIMATI, 1975; MENTEN, 1977; BAJUNGU, 1979; GERALDI, 1981; GHINL, 1984; IGARASHI, 1984; CENTURION, 1985) a metodologia utilizada nos estudos sorológicos foi basicamente a mesma. $O$ antígeno imunizante consistiu de suspensão de esporos (triturados ou não) em concentrações variando de 106 a $109 / \mathrm{ml}$ em solução salina fisiológica, emulsionada com adjuvante completo ou incompleto de Freund. Duas injeções semanais foram aplicadas intramuscularmente em coelhos e após 4 semanas iniciou-se a coleta de amostras de sangue para obtenção do anti-soro. $O$ antígeno utilizado nos testes sorológicos consistiu de extratos de esporos obtidos por trituração em almofariz. O teste utilizado foi o de dupla difusão em ágar.

Embora esta metodologia tenha se mostrado adequada na maioria dos casos, modificações poderiam ser efetuadas a fim de se contornar resultados negativos, como os obtidos por CENTURION (1985). Diferentes formas de obtenção do antígeno imunizante, vias alternativas de injeção, utilização de outras espécies de animais para a produção dos anticorpos e purificação do antígeno imunizante ou reagente, são algumas das possibilidades de modificação na metodologia que poderiam gerar melhores resultados (vide ítem 2.3.).

Anticorpos monoclonais foram utilizados em alguns dos trabalhos mais recentes sobre sorologia de fungos fitopatogênicos. A capacidade discriminatória que pode ser alcançada através destes anticorpos é exemplificada pelos trabalhos de 
HARDHAM et alii (1986), ESTRADA-GARCIA et alii (1989) e WYCOFF \& AYERS (1990) sobre os fungos Phytophthora cinnamomi Rands., Pythium aphamidermatum (Eds.) Fitzp. e Phytophthora megasperma Drech. f. sp. glycinea (Hildeb.) Kuan, respectivamente.

HARDHAM et alii (1986) utilizaram a técnica de anticorpos monoclonais visando a obtenção de anticorpos específicos à $P$. cinnamomi que pudessem auxiliar em estudos taxonômicos. Foram obtidos anticorpos específicos ao isolado estudado, à espécie e ao gênero, assim como anticorpos com reação cruzada com fungos do gênero Pythium. Foi verificado que os anticorpos especificos ao isolado e à espécie ligavam-se à membrana plasmática dos zoósporos, sendo importante, portanto, a indução da formação destas estruturas quando se deseja identificar determinado isolado do fungo. Os autores acreditam que a existência de componentes isolado-especificos pode abrir caminho para o desenvolvimento de testes sorológicos que identifiquem raças fisiológicas do fungo, pois estas ainda não foram determinadas para $P$. cinnamomi.

ESTRADA-GARCIA et alii (1989) também obtiveram anticorpos monoclonais com diferentes níveis de especificidade, porém, estes foram selecionados visando o estudo das moléculas envolvidas no processo de reconhecimento e encistamento dos zoósporos. Anticorpos específicos à membrana do zoósporo, à glicoproteína adesiva e à parede do cisto foram obtidos e, através destes, os autores pretendem estudar a estrutura e função dos componentes da superficie celular, pelos quais os zoósporos ligam-se às plantas e infectam-nas.

WYCOFF \& AYERS (1990) obtiveram 44 linhagens de anticorpos que puderam ser reunidos em 11 grupos, conforme a especificidade de ligação à diferentes epitopos. Foram verificadas diferenças antigenicas entre raças e até mesmo entre isolados da mesma raça, porém os autores não obtiveram sucesso no objetivo principal do trabalho, qual seja, a identificação de epitopos correlacionados aos diferentes genes de avirulência do fungo P. megasperma f. sp. glycinea.

A análise dos trabalhos de sorologia de fungos fitopatogênicos mostra uma diversidade de metodologias de obtenção de anticorpos e de testes sorológicos utilizados. A aplicação de técnicas mais modernas tem permitido melhor caracterização dos componentes antigênicos, distinção entre fungos de grupos taxonômicos próximos entre si, obtenção de anticorpos para moléculas específicas, etc. Com isso a utilidade da sorologia tem se expandido principalmente no estudo da biologia dos fungos e da interação entre patógenos e plantas. 


\subsection{ANTIGENOS COMUNS}

Antígenos comuns ou de reação cruzada são moléculas detectadas através de métodos sorológicos, presentes tanto no patógeno quanto no hospedeiro de uma dada interação. $O$ fato de serem detectados principalmente em combinações compatíveis de planta e patógeno, suscita a possibilidade destes antígenos terem participação no mecanismo de reconhecimento especifico.

Já foi demonstrada a ocorrência de antígenos comuns em inúmeras interações, na sua maioria envolvendo fungos, em menor quantidade bactérias e, em um caso, nematóides (TABELA 1).

Alguns parasitas de animais superiores também apresentam antígenos comuns aos seus hospedeiros. A produção de anticorpos para estas moléculas tem sido responsabilizada como causa de reações auto-imunes que suscedem a infecção por alguns patógenos como micoplasmas, estreptococos e protozoários. Os antígenos comuns presentes em bactérias entéricas do homem poderiam ser considerados como uma forma de mimetismo molecular que permitiria o estabelecimento do microorganismo sem desencadear uma resposta imunológica por parte do hospedeiro (DEVAY \& ADLER, 1976).

A teoria de mimetismo molecular poderia ser aplicada também nas interações patógeno-planta, onde os antígenos comuns permitiriam que os microorganismos penetrassem e se desenvolvessem nos tecidos vegetais sem que fossem reconhecidos como elementos estranhos. Porém, esta inferência deve ser feita com a ressalva de que apesar dos vegetais apresentarem comprovadamente sistemas passivos e ativos de defesa, os modos pelos quais estes atuam não estão suficientemente esclarecidos para que se possa afirmar que o meio interno das plantas exerça pressão de seleção que possa favorecer os microorganismos antigenicamente semelhantes ao hospedeiro.

VANDERPLANK (1982) considera a existência de antígenos comuns a patógenos e hospedeiros como uma das evidências a favor de sua teoria sobre a especificidade em interações onde a teoria gene-a-gene de Flor é valida. Segundo o autor, o reconhecimento nesses tipos de interações se daria através das proteínas codificadas por genes presentes tanto no patógeno como no hospedeiro. $\mathrm{Na}$ suscetibilidade, proteinas do patógeno e do hospedeiro polimerizariam entre si, na interface de contato entre os organismos e, com o crescimento e avanço do patógeno, o polímero iria sendo digerido, constituindo-se numa fonte de proteínas para este. Em 
Tabela 1. Interações nas quais foram detectados antígenos comuns ao patógeno e o hospedeiro

\section{BACTÉRIAS}

Pseudomonas phaseolicola $\times$ Feijão Xanthomonas transhucens $\times$ Trigo

Xanthomonas malvacearum $\times$ Algodão

Rhizobium sp. $\mathrm{x}$ Leguminosas

Rhizobium trifolii $\mathrm{x}$ Trêvo branco

Agrobacterium tumefaciens $\mathrm{x}$ Girassol
Fedotova (citada por DEVAY \& ADLER, 1976)

Fedotova (citada por DEVAY \& ADLER, 1976 )

Fedotova (citada por DEVAY \& ADLER, 1976),

SCHNATHORST \& DEVAY, 1963

CHARUDATTAN \& HUBBELL (1973)

DAZZO \& HUBBELL (1975)

DEVAY et alii (1970)

\section{FICOMICETOS}

Phvtophthora infestans $\times$ Batata

Phytophthorafragartae $\times$ Morango
PALMERLEY \& CALLOW (1978), ALBA \& DEVAY (1985)

MOHAN (1989)

\section{ASCOMICETOS}

Ceratocystis fimbriata $\times$ Batata doce Colletotrichum corchori $x$ Juta Ophiobolus graminis $\times$ Trigo e Aveia Erysiphe graminis f. sp. hordei $\mathrm{x}$ Cevada

DEVAY et alii (1967)

BATTACHARYYA \& PURKAYASTHA (1985)

Abbott (citado por DEVAY \& ADLER, 1076)

HEIDE \& SMEDEGAARD-PETERSEN (1985)

\section{DEUTEROMICETOS}

Fusarium semitectum $\times$ Melancia

$F$. oxysporum f. sp. vasinfectum $\mathrm{x}$ Algodão

Verticillium dahliae $\mathrm{x}$ Algodão

Fusarium solani $x$ Algodão

Fusarium solani $x$ Ervilha

Macrophomina phaseolina $\times$ Soja

Accrocvlindrium oryzae $\mathrm{x}$ ATOZ
ABD-EL-REHIM et alii (1971)

CHARUDATTAN \& DEVAY (1972), ABD-EL-

REHIM et alii (1988a e b)

CHARUDATTAN \& DEVAY (1972)

CHARUDATTAN \& DEVAY (1972)

SCALA \& CRISTTNZIO (1988)

CHAKRABORTY \& PURKAYASTHA (1983)

PURKAYASTHA \& GHOSAL (1985)

\section{BASIDIOMICETOS}

Melampsora lini $\mathrm{x}$ Linho

Ustilago mavdis $\mathrm{x}$ Milho

Hemileia vastatrix $\mathrm{x}$ Café
DOUBL $Y$ et alii (1960)

WIMALAJEEWA \& DEVAY (1971)

ALBA et alii (1983)

\section{NEMATÓIDES}

McCLURE et alii (1973)

ABBOTT, L. K. Texonomy and host-specifioity of Ophibolus graminis Sace; an applioation of electrophoretic and serological techniques. Clayton, 1973. 200p. (PhD - Monash University/ Australia).

FEDOTOVA, T. I. Leningrad. Inst. Zashch. Rast. Sbom. Trud. 1:62-71, 1948. 
interações incompatíveis, o polimero não se formaria impedindo o fluxo de proteínas para o patógeno e consequentemente causando a morte deste. $O$ polímero se formaria devido a existência de um sítio A na proteína do patógeno, complementar a um sítio $\mathrm{B}$ da proteína da planta. Para que a polimerização vá além da formação de um dímero, é necessário que a proteina da planta apresente um outro sítio idêntico ao A que se ligaria a uma proteína do patógeno que apresente um sítio idêntico ao $\mathrm{B}$, ou seja, o polímero se formaria desde que proteínas do patógeno e da planta apresentassem sítios em comum. Esses sítios, se antigênicos, corresponderiam aos antígenos comuns detectados nas interações compatíveis.

Apesar de sua função não estar estabelecida, a presença dos antigenos comuns foi correlacionada por Fedotova (citada por DEVAY \& ADLER, 1976) à suscetibilidade de cultivares de feijão (Phaseolus vulgaris L.), trigo, algodão e melancia (Citrullus vulgaris Shrad.) aos patógenos Pseudomonas phaseolicola (Burk.) Dowson, Xanthomonas translucens Bradbury, Xanthomonas malvacearum (Smith) Dowson e Fusarium semitectum Berk. et Rav., respectivamente. A autora utilizou a serodiagnose como ferramenta de seleção de cultivares resistentes à doenças em programas de melhoramento genético na ex-União Soviética. Neste particular vale a lembrança do período compreendido entre as décadas de 40 a 60 , quando a ciência soviética esteve sob forte domínio do Partido Comunista, representado por Trofim D. Lysenko, então presidente da Academia Lênin de Ciências Agrícolas. Além dos aspectos negativos deste periodo, como a crença na herdabilidade de características adquiridas (Michurinismo-Lamarckismo), a negação da genética mendeliana e a perseguição de cientistas "impatrióticos", os soviéticos, de acordo com o materialismo dialético preconizado pelo Partido, salientavam uma pesquisa pragmática e voltada ao progresso em oposição à inútil pesquisa acadêmica burguesa praticada no ocidente (HUXIEY, 1949).

DOUBLY et alii (1960) também verificaram correlação entre a presença de antígenos comuns e a compatibilidade entre cultivar do hospedeiro e raça do patógeno. Utilizando-se antígenos extraídos de 4 variedades diferentes de linho (Linum usitatissimum L.) e anti-soro para 4 raças de Melampsora lini (Pers.) Lev., foi verificado título elevado (1:160 ou 1:320) somente nas reações antígeno-anticorpo envolvendo variedade e raça compativel e título baixo (1:20 ou 1:40), nas interações incompativeis. Esta correlação não foi verificada quando utilizado antígeno do fungo e anti-soro para a planta. 
WIMALAJEEWA \& DEVAY (1971) detectaram antigenos comuns a Ustilago maydis (DC.) Cda. e milho. $\mathrm{O}$ anti-soro para antígenos do fungo reagiu com antígenos do milho, assim como o anti-soro para o milho reagiu com antígenos do fungo. Devido a inexistência de linhagens de mïho resistentes ao patógeno, foram utilizadas a aveia e a cevada como plantas resistentes. Plantas jovens de aveia, que são suscetiveis a $U$. maydis, apresentaram antígenos comuns ao fungo enquanto que plantas mais velhas, que são resistentes, apresentaram decréscimo na quantidade de antígenos comuns. Através de centrifugação diferencial chegou-se a conclusão que os antígenos comuns se encontravam na fração ribossomal do extrato antigênico, tanto do milho como do fungo. Segundo os autores, a ocorrência desses antigenos seria uma característica das interações compativeis mas não garantiria o estabelecimento de uma condição de doença, eles representariam somente uma etapa inicial no processo de infecção sendo que outras etapas, como a ocorrència de toxinas do hospedeiro, precisariam ser posteriormente ultrapassadas.

Esta hipótese foi reformulada em trabalho posterior de CHARUDATTAN \& DEVAY (1972) no qual os antígenos comuns foram detectados em interações compativeis e incompatíveis entre cultivares de algodão e os patógenos $F$. axysporum f. sp. vasinfectum, Fusarium solani f. sp. phaseoli (Burk.) Snyder et Hansen e Verticillium albo-atrum Reinke et Berth. Como a expressão de resistência do algodão a estes patógenos só ocorre após a infeç̧ão das raízes e irvasão do sistema vascular, os antígenos comuns estariam relacionados a esta compatibilidade inicial e não a suscetibilidade ou resistência dos cultivares, ou seja, seriam determinantes do parasitismo mas não da patogenicidade, ou segundo o conceito de outros autores, seriam determinantes da patogenicidade mas não da virulência.

CHARUDATTAN \& DEVAY (1981) realizaram purificação e caracterização parcial da molécula antigênica comum ao algodão e $F$. axysporum $\mathrm{f}$. sp. vasinfectum. A partir de extrato de conídios do fungo, através de centrifugação e precipitação com ácido tricloroacético e sulfato de amônio, obtiveram um antígeno comum que em eletroforese e ultracentrifugação analítica migrava e sedimentava como banda única. Este antígeno mostrou-se resistente à ação de diversas proteases, apresentando composição de $75 \%$ de carboidratos, $9 \%$ de proteínas e $16 \%$ de fósforo. A injeção deste antígeno purificado em coelhos, resultou em um anti-soro que formava uma única linha de precipitação em teste de dupla difusão em ágar na reação com antígenos totais de conídios do fungo. Os autores especularam a possibilidade de que, 
devido à semelhança na natureza glicoproteica dos antígenos comuns e dos supressores de elicitores de fitoalexinas, estas moléculas apresentem funções semelhantes.

DEVAY et alii (1981) verificaram que, através de técnica de imunoftuorescência, o antígeno comum ao algodão e $F$. cxysporum $\mathrm{f}$. sp. vasinfectum localizava-se, em cortes de raízes, principalmente ao redor de elementos do xilema, endoderme e células epidérmicas mas também podia ser detectado por todo o córtex, indicando ampla distribuição no tecido. No fungo, o antígeno comum localizava-se principalmente nas pontas das hifas e em áreas localizadas do conídio. Foi observado também que plantas de algodão crescidas à $24^{\circ} \mathrm{C}$ apresentavam menor concentração do antígeno do que plantas crescidas à $33^{\circ} \mathrm{C}$, paralelamente ao fato de que as primeiras mostraram-se resistentes ao patógeno e as últimas suscetiveis.

Relação sorológica entre cultivares resistentes e suscetíveis de batata (Solanum tuberosum L.) e a raça 4 de Phytophthora infestans (Mont.) de Bary, foi observada por PALMERLEY \& CALLOW (1978). Foram incluidos no estudo um hospedeiro alternativo, o tomate (Lycopersicum esculentum Mill.) e não-hospedeiros, como o pepino (Cucumis sativus L.), milho, mungo (Phaseolus aureus Roxb.), ervilha (Pisum sativum L.), gerànio (Pelargonium zonale L'Her, ex Soland in Ait.), perila (Perilla frutescens (L.) Britt.), nabo (Raphanus sativus L.) e fumo (Nicotiana tabacum L.) além de um patógeno alternativo (Fusarium caeruleum Lib. ex Sacc.) e nãopatógenos ( $P$. cinnamomi e $U$. maydis). Tomate e fumo, ambas pertencentes à família das solanáceas, também apresentaram reação cruzada com $P$. infestans, o mesmo não tendo sido observado para as demais plantas. O patógeno alternativo e os não-patógenos não apresentaram relação sorológica com a batata. Esta ocorrência relativamente especifica de antígenos comuns a plantas e fungo sugere que tais antígenos podem ser relevantes ao parasitismo e não seriam simples exemplos de antígenos "heterófilos", isto é, antígenos altamente conservados entre espécies de origem filogenética diversa. Os autores acreditam que o fato de terem utilizado antígenos solúveis totais, ao invés de somente antígenos da superfície celular, tenha impossibilitado a detecção de uma grande quantidade de relações sorológicas mais fracas, existentes entre o hospedeiro e o patógeno. Seguindo este raciocínio, antígenos comuns poderiam ser encontrados mesmo entre patógenos e plantas não-hospedeiras, mas somente a presença de algunas antigenos comuns "chave" seriam importantes na determinação da compatibilidade.

ALBA \& DEVAY (1985) obtiveram evidências a favor das idéias acima descritas, utilizando o teste de ELISA ("enzyme linked immunosorbent assay"). Os 
antígenos extraídos a partir do fungo foram submetidos a precipitação fracionada com sulfato de amônio em diferentes níveis de saturação (20\%,40\%,60\% e 80\%). Foram detectados antígenos comuns em todas as frações porém em maior concentração na fração de $40 \%$ de saturação do sal. Verificaram também que nesta fração, antígenos da raça 4 de $P$. infestans reagiam com maior intensidade com anti-soro de cultivar suscetível de batata que de cultivar resistente. As demais frações não apresentaram esta diferença. Antígenos da raça 1.2.3.4.7. de $P$. infestans, virulenta a ambos cultivares de batata testados, não apresentaram estas diferenças em qualquer das frações. Os resultados indicam uma heterogeneidade dos antígenos comuns, pois foram detectados nas várias frações precipitadas com diferentes niveis de saturação do sulfato de amônio, e que os antígenos comuns "chave", importantes na determinação da compatibilidade, se encontrariam na fração precipitada com $40 \%$.

Esta heterogeneidade quanto aos antígenos comuns foi detectada também por MOHAN (1989), na interação entre morango e Phytophthora fragariae Hickman. Antígenos miceliais extraídos de 5 isolados de diferentes raças do fungo, quando testados com anti-soro produzido para antígenos da planta, apresentaram várias bandas em "western blotting", correspondentes a antígenos comuns de diferentes pesos moleculares. Na situação inversa, utilizando antígenos extraídos da planta e anti-soro para o fungo, foram detectadas até 6 bandas correspondentes aos antígenos comuns. Estudando a presença destes antígenos em plantas inoculadas com raças virulentas e avirulentas do patógeno, o autor levantou a possibilidade de alguns antígenos comuns observados estarem relacionados à compatibilidade e outros à incompatibilidade da interação.

CHAKRABORTY \& PURKAYASTHA (1983) também verificaram heterogeneidade para os antígenos comuns a Macrophomina phaseolina (Tassi) Goid e soja (Glycine max (L.) Merrill). Através de imunoeletroforese, foram detectadas até 4 linhas de precipitação correspondentes aos antígenos comuns.

PURKAYASTHA \& GHOSAL (1985), através de metodologia semelhante, verificaram ocorrência de somente uma linha de precipitação correspondente ao antígeno comum a Accrocylindrium oryzae Sawada e arroz. Porém, em comum ao trabalho anterior, os autores observaram reação cruzada somente em combinações compatíveis de cultivares da planta e isolados do fungo.

HEDE \& SMEDEGAARD-PETERSEN (1985) detectaram um antígeno comum a cevada e Erysiphe graminis DC. f. sp. hordei Em. Marchal, o 
mesmo não foi verificado entre esse fungo e espécies não-hospedeiras como a aveia, trigo, ervilha e feijão. 4 linhagens quase-isogênicas de cevada, portadoras de diferentes genes de resistência ao oídio, apresentaram antígenos comuns ao fungo, tanto nas combinações compatíveis como nas incompatíveis. Análise quantitativa, realizada através de imunoeletroforese em foguete ("rocket immunoelectrophoresis"), do antígeno comum presente nas diferentes linhagens quase-isogênicas, não indicaram qualquer relação entre a concentração do antígeno e a compatibilidade entre linhagem do hospedeiro $\mathrm{e}$ isolado do fungo.

SCALA \& CRISTINZIO (1988) observaram a ocorrência de antigenos comuns ao fungo $F$. solani e as plantas hospedeiras ervilha e grão-de-bico (Cicer arietinum $\mathrm{L}$.). Os autores detectaram estes antígenos em reações de anti-soro para o fungo com antígenos das plantas e vice-versa. Plantas não-hospedeiras como tomate, cenoura (Daucus carota L.), couve-flor (Brassica oleracea L. var. Botrytis-cauliflora) e abóbora (Cucurbita pepo L.) não apresentaram reação com anti-soro para o fungo. Antisoro para antígenos da ervilha não reagiu com antígenos dos não-patógenos $F$. moniliforme, $F$. axysporum f. sp. lycopersici e Phytophthora capsici Leonian. Os antígenos comuns extraídos tanto do fungo como da ervilha foram purificados através de cromatografia de imunoafinidade e, quando analisados em eletroforese em gel de poliacrilamida com SDS (dodecil sulfato de sódio), apresentaram pesos moleculares diferentes. Isolado avirulento do fungo também apresentou o antígeno comum, o que, segundo os autores, indica o envolvimento destas moléculas com a compatibilidade básica entre planta e patógeno, mas não com a patogenicidade.

ABD-EL-REHIM et alii (1988a) confirmaram a ocorrência de antígenos comuns ao algodão e $F$. axysporum $\mathrm{f}$. sp. vasinfectum. Anti-soro produzido para o fungo reagiu com lectinas extraídas de sementes de cultivares suscetíveis de algodão, mas não com aquelas extraídas de cultivar resistente. Neste trabalho não foi realizado qualquer experimento visando confirmar que os antigenos comuns tratavam-se realmente de lectinas, ou seja, proteinas ou glicoproteínas com capacidade de se ligar especificamente a carboidratos, portanto, a caracterização destes antígenos como sendo lectinas é questionável.

Relação entre lectinas e antígenos comuns foi relatada anteriormente por DAZZO \& HUBBELL (1975), na interação de Rhizobium trifolii Dangeard com o trêvo (Trifolium repens L.). Foi verificado que o antígeno comum presente na superficie das raízes da planta e no exopolissacarídeo (EPS) de "strains" 
infectivos da bactéria, apresentavam afinidade por uma lectina produzida pelo trèvo que, sendo multivalente, propriciaria a ligação da bactéria aos pêlos absorventes da planta.

Em trabalho posterior ABD-EL-REHIM et alii (1988b) modificaram o método de extração de antígenos da semente e, talvez pelos motivos acima citados, passaram a denominar as proteínas obtidas como globulinas e não mais como lectinas. Segundo classificação bioquímica, globulinas são proteínas insolúveis em água mas solúveis em soluções salinas de baixas concentrações. Neste trabalho foi verificada a ocorrència de antigenos comuns tanto em cultivares suscetíveis como nos resistentes, porém, o número de linhas de precipitação observado para os últimos foi sempre menor que para os primeiros. A ocorrência de múltiplas linhas de precipitação correspondentes aos antígenos comuns (até 8 linhas observadas) confirma a heterogeneidade destas moléculas.

A heterogeneidade dos antígenos comuns detectada nos trabalhos de ALBA \& DEVAY (1985), ABD-EL-REHIM et alii (1988a e b), MOHAN (1989) e CHAKRABORTY \& PURKAYASTHA (1983) não significa necessariamente que essas moléculas sejam completamente diferentes entre si e que para cada uma foi produzido um anticorpo específico. Os antigenos comuns de diferentes pesos moleculares poderiam ser glicoproteinas com a fração peptídica de tamanho variável mas com epitopos glicosídicos idênticos, de modo que um mesmo tipo de anticorpo poderia estar se ligando a antígenos de diferentes tamanhos. Sítios glicosídicos comuns a glicoproteínas de pesos moleculares variados já foram demonstrados tanto em plantas como em fungos (LAINE \& FAYE, 1988; WYCOFF et alii, 1987).

Fenômeno de mimetismo molecular parece ocorrer também entre Rhizobium leguminosarum (Frank) Frank e leguminosas, em fases posteriores à penetração, quando a bactéria ocorre na forma de bacteróides. BREWW et alii (1986) detectou através de anticorpos monoclonais e "immunoblotting", diferenças entre bactérias crescidas em meio de cultura e bacteróides extraídos de nódulos. Os bacteróides são envolvidos por cadeias de ácido poligalacturônico, que conferem a sua superficie uma alta densidade de cargas negativas e a toma semelhante estruturalmente à pectina. Os autores acreditam que desta maneira os bacteróides evitariam serem detectados como corpos estranhos por apresentarem uma superficie com propriedades físico-químicas semelhantes as da parede celular primária das plantas.

ALBA et alii (1973) realizaram os primeiros estudos sorológicos sobre o fungo $H$. vastatrix. Foram produzidos anti-soros para a raça II da ferrugem e 
para cafeeiros suscetivel e resistente. Foi verificada reação somente entre os antigenos e seus anti-soros homólogos. A não detecção de antígenos comuns poderia ser explicada, segundo os autores, pela metodologia utilizada na preparação dos antígenos fúngicos e das plantas, a qual teria resultado em extratos pouco concentrados, ou pela possibilidade do parasitismo de $H$. vastatrix ser um tipo de interação diferente das reportadas por outros autores, nas quais tais antigenos haviam sido detectados. $O$ sucesso na obtenção de anti-soro para a raça II de $H$. vastatrix, que não reagiu com antígenos de outras ferrugens (Puccinia sorghi Schw. e Puccinia psidii Wint.), encorajava a continuidade dos experimentos no sentido de se obter anti-soros específicos para as demais raças.

Dando prosseguimento a estes trabalhos, Al.BA et alii (1983) lograram detectar antígenos comuns a cafeeiro e $H$. vastatrix. Em relação ao trabalho anterior houve modificações no método de obtenção dos antigenos que resultaram em extratos mais concentrados. Os anti-soros, tanto para o fungo como para a planta, detectaram antígenos comuns em reações heterólogas. Tais antígenos parecem estar localizados na superficie externa dos urediniosporos pois puderam ser extraídos através de simples agitação em água. $O$ extrato fúngico foi submetido a precipitação com sulfato de amônio a $50 \%, 70 \%$ e $100 \%$ de saturação e em todos os precipitados obtidos, os antigenos comuns estavam presentes. Este mesmo extrato, submetido a precipitação com etanol a $80 \%$ de concentração final, também apresentou antígenos comuns no precipitado. Os antígenos das plantas foram extraidos a partir do pó cetônico de folhas e, posteriormente, submetidos a precipitação fracionada com sulfato de amônio (20\%, $40 \%, 60 \%, 80 \%$ e $100 \%$ de saturação) e etanol $(20 \%, 40 \%, 60 \%$ e $80 \%$ de concentração final). Dos precipitados obtidos com o sulfato de amônio, somente $o$ correspondente a $80 \%$ de saturação apresentou antígenos comuns, tanto para a planta resistente como para a suscetivel. Na precipitação etanólica, o sedimento obtido com $80 \%$ de concentração do álcool apresentou antígenos comuns em ambas as plantas enquanto que o sedimento de $60 \%$ apresentou antígenos comuns somente no caso de planta suscetível. Além desta diferença, foi verificado que os antígenos comuns podiam ser detectados em diluíções mais elevadas dos extratos e precipitados de planta suscetivel que de planta resistente. Segundo os autores, os resultados suportam o conceito de que em interações incompativeis a disparidade antigênica seria maior que nas interações compatíveis, o que ocasionaria uma resposta inibitória por parte do hospedeiro no primeiro caso. Os antígenos comuns relevantes para a determinação da compatibilidade entre $H$. vastatrix e $C$. arabica estariam no precipitado obtido com $60 \%$ de 
concentração de etanol, o que estaria de acordo com as conclusões de PALMERLEY \& CALLOW (1978), de que nem todos antígenos comuns seriam importantes na determinação da compatibilidade, mas somente alguns antígenos comuns "chave".

A análise dos trabalhos relativos aos antígenos comuns permite fazer as seguintes considerações:

-são detectados principalmente em combinações compativeis de espécie de planta hospedeira e espécie de patógeno (DEVAY \& ADLER, 1976),

-quando detectados em plantas não-hospedeiras, estas são taxonomicamente próximas às plantas hospedeiras (mesmo gênero ou familia) (PALMERLEY \& CALLOW, 1978), -alguns trabalhos indicam que para cada interação podem existir várias moléculas antigênicas em comum, de diversos pesos moleculares. Isto pode ser demonstrado pelo fato de serem detectadas em diferentes frações obtidas em precipitação fracionada com sulfato de amônio ou etanol, através da visualização de várias linhas de precipitação em testes de dupla difusão em ágar ou imunoeletroforese, ou várias bandas em "western blotting" (ALBA et alii, 1983; ALBA \& DEVAY, 1985; ABD-EL-REHM et alii, 1988a e b; MOHAN, 1989; CHAKRABORTY \& PURKAYASTHA, 1983),

-as moléculas em comum ao patógeno e planta não são necessariamente idênticas (mesmo peso molecular) mas podem apresentar epitopos antigênicos em comum (SCALA \& CRISTINZIO, 1988; MOHAN, 1989),

-em alguns trabalhos diferenças na concentração de antigenos comuns entre raças virulentas e avirulentas ou entre cultivares resistentes e suscetiveis puderam ser evidenciadas pelo número de linhas de precipitação observadas em testes sorológicos, pela intensidade de reação em teste de ELISA ou pelo padrão de bandas formadas em "western blotting" (ALBA et alii, 1983; ALBA \& DEVAY, 1985; ABD-EL-REHM et alii, 1988a e b; MOHAN, 1989; CHAKRABORTY \& PURKAYASTHA, 1983).

\subsection{METODOLOGIAS EMPREGADAS PARA OBTENÇÃO DE ANTICOR- POS}

Nos trabalhos citados sobre sorologia de fungos fitopatogênicos e antígenos comuns, o coelho destaca-se como o animal mais utilizado para a produção de anticorpos. As facilidades proporcionadas por sua utilização, já citadas anteriormente (ítem 1.), explicam esta predominância. 
HORNOK (1980) utilizou ratos, ao invés de coelhos, em seu trabalho de sorotaxonomia de espécies de Fusarium. Foram produzidos anti-soros para 13 espécies diferentes do fungo, sendo que para cada uma foram utilizados 10 animais, a fim de se obter uma caracterização mais consistente dos componentes antigênicos. $O$ número elevado de animais utilizado explica o porquê da utilização de animais de menor porte para a produção dos anticorpos.

Camundongos foram utilizados em trabalhos nos quais se empregou a técnica de anticorpos monoclonais (HARDHAM et alii, 1986; ESTRADA-GARCIA et alii, 1989; WYCOFF et alii, 1987. Nestes casos, a utilização destes animais é uma imposição da técnica, pois as células de mieloma comercialmente disponiveis para a produção de hibridomas são compativeis com células de camundongos.

Animais de maior porte como a cabra, carneiro e cavalo são utilizados quando maior quantidade de anti-soro se faz necessária, o que raramente ocorre nos trabalhos sobre fungos fitopatogênicos.

Após a publicação de vários trabalhos descrevendo métodos de purificação dos anticorpos presentes nas gemas dos ovos, galinhas poedeiras passaram a ser utilizadas com maior frequência (POLSON et alii, 1980 e 1985; JENSENIUS et alii, 1981; BADE \& STEGEMANN, 1984; VIEIRA et alii, 1984; HASSL \& ASPOCK, 1988).

Os antígenos utilizados na imunização dos animais são geralmente obtidos por uma das seguintes maneiras: extrato de micélio triturado (MORTON \& DUKES, 1966), extrato de conídios rompidos por ultra-som (RATAJ-GURANOWSKA et alii, 1984), suspensão de conídios intactos (KMMATI, 1975), filtrado de suspensão de esporos em água (ALBA et alii, 1983). Em alguns casos, as proteínas presentes no extrato micelial sofrem ainda precipitação com sulfato de amônio, para então serem utilizadas na imunização (CHAKRABORTY \& PURKAYASTHA, 1983).

$O$ antígeno imunizante é geralmente emulsionado com um agente adjuvante, com a finalidade de intensificar a resposta imunológica do animal. $O$ adjuvante completo de Freund, composto de suspensão de micobactéria morta em óleo mineral, é o mais utilizado. $O$ adjuvante incompleto costuma ser utilizado nas doses de reforço ("booster") pois, por não conter a micobactéria, não causa problemas de hipersensibilização do animal. $O$ alginato de sódio também pode ser utilizado como adjuvante, porém são poucos os autores que o empregam.

Nos estudos sobre os antígenos comuns, os antígenos imunizantes 
são extraídos das plantas hospedeiras a partir de suas folhas ou raizes congeladas com gelo seco ou $\mathrm{N}_{2}$ líquido e trituradas em almofariz com auxílio de abrasivos como alumina, areia ou pó de vidro. $O$ pó resultante da trituração é suspendido em tampão adicionado de agentes redutores como o ácido ascórbico ou mercaptoetanol, que impedem o acúmulo de quinonas, e também de polimeros que adsorvem compostos fenólicos, como a polivinilpirrolidona (PVP) insolúvel (HALL et alii, 1974).

$\mathrm{Na}$ extração de antígenos de sementes com alto teor de óleo, como no caso do algodão, toma-se necessária uma etapa de delipidificação do triturado com éter de petróleo para, posteriormente, realizar-se a extração dos antígenos solúveis em tampão (ABD-EL-REHIM et alii, 1988a e b).

Para a inoculação dos antígenos, as seguintes vias são as mais utilizadas: intravenosa, intramuscular, intralinfonódulo, intraperitonial e subcutânea. Em muitos casos, uma combinação de duas ou mais vias diferentes são utilizadas concomitantemente.

De um trabalho para outro são encontradas grandes variações nos cronogramas de imunização. São utilizados desde métodos intensivos, com inoculações diárias por várias vias simultâneamente (CHARUDATTAN \& DEVAY, 1972), até métodos prolongados, com espaço de mais de um mês entre uma injeção e outra (ALBA et alii, 1983).

A sangria em coelhos é feita principalmente pela veia marginal da orelha, ou com menor frequência, por punção cardíaca. Costuma-se manter o animal em jejum por um dia, antes da sangria.

O sangue coletado é deixado em temperatura ambiente por 2 horas, para que ocorra a formação do coágulo, e por mais algumas horas em refrigerador, para que haja liberação do soro. Hemáceas, quando presentes no soro, podem ser removidas por centrifugação. Ao soro é adicionado algum preservativo, como o thimerosal ou azida de sódio, sendo então mantido em congelador para posterior utilização.

Geralmente, os anti-soros são utilizados na sua forma bruta, porém, em alguns casos é necessário concentrá-los, o que pode ser feito através de uma das seguintes maneiras: liofilização, absorção da água com substâncias como o Sephadex G25 ou Bio-Gel P2, diálise contra soluções concentradas de moléculas inertes de alto peso molecular (polivinilpirrolidona ou polietilenoglicol), diálise contra sacarose, ultrafiltração, evaporação da água através de membrana de diálise (CROWLE, 1973).

A técrica de absorção tem sido utilizada para a obtenção de anti- 
soros com maior especificidade. Utilizando este recurso, MORTON \& DUKES (1966) conseguiram diferenciar sorologicamente as raças 1 e 2 de $F$. oxysporum $f$. sp. lycopersici.

Os anticorpos presentes no anti-soro podem também sofrer purificação através de precipitação com sulfato de amônio seguida de cromatografia em coluna de DEAE Sephadex A-50 (HORNOK, 1980) ou coluna de CN-Br (brometo de cianogênio) Sepharose 4B à qual antígenos específicos foram acoplados (MOHAN, 1989).

A metodologia dos anticorpos monoclonais tem sido aplicada no estudo de fungos fitopatogênicos com frequência cada vez maior. Enquanto que nos métodos convencionais obtem-se uma mistura de anticorpos, com especificidade aos vários sítios antigênicos presentes nas moléculas injetadas (anti-soro policlonal), no método mais moderno, através de uma separação das linhagens de células produtoras de anticorpos, obtêm-se diferentes culturas, cada uma produzindo somente um tipo de anticorpo. Esta metodologia é constituída, resumidamente, pelos seguintes passos: imunização do animal, extração do baço e homogeneização do órgão, fusão das células produtoras de anticorpos com células cancerosas de mieloma (obtenção dos hibridomas), seleção dos hibridomas produtores dos anticorpos desejados, clonagem dos hibridomas. Esta técnica foi empregada com sucesso em trabalho recentes como os de HARDHAM et alii (1986), ESTRADA-GARCIA et alii (1989) e WYCOFF \& AYERS (1990), já descritos anteriormente.

\subsection{UTILIZAÇÃO DE ANTICORPOS EXTRAÍDOS DE OVOS POSTOS POR GALINHAS POEDEIRAS IMUNIZADAS}

Apesar de apresentar resposta imunológica comparável a de mamíferos, galinhas e aves em geral têm sido pouco utilizadas para a produção de anticorpos, devido principalmente ao pequeno volume de anti-soro que pode ser obtido a partir das sangrias (CARROLL \& STOLLAR, 1983).

Esse incoveniente tem sido contornado atualmente pela extração dos anticorpos a partir da gema de ovos postos por galinhas imunizadas. A transferência em larga escala de imunoglobulinas do soro sanguíneo para as gemas dos ovos já havia sido demonstrada por PATERSON et alii (1962) e constituiria numa forma de 
transferência de imunidade da mãe para os filhotes, similar a que ocorre em mamíferos através da placenta. Porém, a inexistência de métodos adequados à extração desses anticorpos, rotineiramente, impedia um melhor aproveitamento deste fenômeno.

Esta situação foi modificada durante a década de 80 , com a publicação de inúmeros trabalhos referentes a purificação de anticorpos a partir da gema de ovos (POLSON et alii, 1980 e 1985; JENSENIUS et alii, 1981; BADE \& STEGEMANN, 1984; VIEIRA et alii, 1984; HASSL \& ASPOCK, 1988).

Dentre os vários protocolos, o que tem sido mais utilizado é o de POLSON et alii (1980), o qual foi aprimorado posteriormente (POLSON et alii, 1985). Basicamente, o método envolve a diluição da gema em tampão, eliminação da fração sólida atraves de precipitação com polietilenoglicol (PEG) a concentração de 3,5\% p/v e posterior precipitação dos anticorpos com PEG a concentração de $12 \% \mathrm{p} / \mathrm{v}$. Contaminação pelo PEG junto aos anticorpos precipitados, pode ser eliminada através de reprecipitação com sulfato de amônio a $33 \%$ de saturação ou etanol a $25 \% \mathrm{v} / \mathrm{v}$, seguida de diálise. $\mathrm{Na}$ versão aprimorada de 1985, os autores conseguiram um melhor rendimento na quantidade de anticorpos extraídos, simplesmente aumentando o volume de tampão no qual as gemas são diluídas inicialmente.

JENSENIUS et alii (1981) descreveram dois métodos de extração, sendo o primeiro baseado em eliminação das lipoproteinas por precipitação com sulfato de dextrana e o segundo, na utilização da agregação dos lipídios em soluções de baixa força iônica e $\mathrm{pH}$ neutro. Ambos os métodos são seguidos de precipitação com sulfato de sódio e diálise.

BADE \& STEGEMANN (1984) basearam seu método na precipitação de proteínas em solventes orgânicos, no caso o propanol e acetona. Para cada gema, o volume de solvente necessário é bastante elevado ( $400 \mathrm{ml}$ de propanol e $200 \mathrm{ml}$ de acetona), o que torna esta metodologia pouco acessivel.

HASSL \& ASPOCK (1988) compararam metodologia própria, baseada em cromatografia de interação hidrofóbica e filtração em gel, com o método de POLSON et alii (1985). A partir de um ovo de $60 \mathrm{~g}$, conseguiram extrair $14,5 \mathrm{mg}$ de anticorpos, menos que a metade obtida pelo outro método. Em termos de atividade dos anticorpos, as duas metodologias foram equivalentes. Os autores afirmam ser o método deles uma alternativa viável, com a vantagem de ser mais rápido que o método de POLSON et alii (1985).

Um grupo de pesquisadores da Escola Paulista de Medicina utilizou 
anticorpos extraídos de ovos, para o desenvolvimento de radioimunoensaio para o paratormònio humano. VIEIRA et alii (1984 e 1986) separaram as imunoglobulinas das lipoproteínas e lipídios das gemas através de precipitação com cloreto de magnésio e ácido tungstofosfórico, seguida de precipitação com sulfato de amônio e diálise.

A utilização de galinhas poedeiras associada aos métodos de extração dos anticorpos dos ovos por elas postos tem sido apontada como vantajosa por diversos pesquisadores, pelos seguintes aspectos:

- grande quantidade de anticorpos produzidos (equivalente a $100 \mathrm{ml}$ de anti-soro, por semana, produzido por uma galinha,

- manutenção de títulos elevados por períodos prolongados. com menor necessidade de injeções de reforço,

- não necessidade de sangrias,

- obtenção do pico de produção de anticorpos em poucos dias,

- facilidades na manutenção dos animais, sob aspectos alimentares, sanitário e de prevenção ou incidência de doenças,

- o processo de purificação resulta num sedimento contendo anticorpos que pode ser retomado em volume que o pesquisador julgar conveniente.

Em algumas situações, a utilização de galinhas é fundamental para o sucesso na obtenção de anticorpos reativos, como nos casos onde os antígenos são oriundo de mamíferos. Certas moléculas são altamente conservadas dentro desta classe animal, o que as tornam pouco imunogênicas quando inoculadas em qualquer animal da mesma classe. As galinhas, sendo filogeneticamente distantes dos mamíferos, são mais propicias a reagirem contra estes antígenos. Valendo-se deste fenômeno, CARROLL \& STOLLAR (1983) conseguiram anticorpos específicos para uma polimerase de RNA extraída de timo de bezerro, SONG et alii (1985) produziram anticorpos específicos para uma sub-unidade do receptor da insulina e VIEIRA et alii (1984 e 1986) puderam obter anticorpos para o radioimunoensaio do paratormônio humano.

São poucos os trabalhos envolvendo agentes fitopatogênicos, nos quais empregaram-se anticorpos extraidos de ovos de galinhas imunizadas. Dentre estes temos o de BAR-JOSEPH \& MALKINSON (1980), que utilizaram estes anticorpos em teste de ELISA, para a deteç̧ão do vírus da tristeza de plantas cítricas e do virus do mosaico do fumo (isolado do abacate). No trabalho de POLSON et alii (1980) que descreve a metodologia de purificação dos anticorpos a partir da gema, também foram utilizados virus fitopatogennicos, como os causadores do mosaico do fumo, mosaico do 
capim-cevadinha e mosaico amarelo do nabo, entre outros.

Trabalhos recentes de NOVAK \& KOHN (1990) e BURDSALL et alii (1990) empregaram estes anticorpos em estudos taxonômicos, respectivamente, de fungos dos gêneros Aspergillus e de fungos dos gêneros Armillaria e Lentinula.

A aplicação destes anticorpos pode se extender a outras áreas como a tecnologia de alimentos. SHIMIZU et alii (1988) verificaram que os anticorpos presentes nas gemas dos ovos eram resistentes ao processo de pasteurização, às enzimas proteolíticas gastrointestinais e ao ambiente ácido do estômago, de modo que poderiam atingir o intestino ainda ativos. Se galinhas poedeiras forem imunizadas contra bactérias e vírus causadores de diarréias no ser humano, os anticorpos por elas produzidos poderiam servir como aditivos em alimentos, especialmente aqueles voltados ao público infantil.

As imunoglobulinas (Ig) encontradas nas gemas dos ovos de galinhas são as mesmas que predominam no soro sanguineo destes animais e têm sido erroneamente designadas como imunoglobulina $\mathrm{G}$ (IgG) em analogia a mamíferos, que têm esta Ig como principal componente de seus anti-soros. LESLIE \& CLEM (1969) verificaram ocorrência de 2 tipos de Ig em galinhas, uma semelhante à IgM humana e outra com valores de peso molecular e coeficiente de sedimentação ligeiramente diferentes da IgG de mamíferos. Os autores não puderam correlacionar estas últimas com qualquer das Ig de mamíferos ( $\operatorname{IgG}, \operatorname{Ig} A, \operatorname{IgD}, \operatorname{IgE}$ ou $\operatorname{IgM}$ ) e propuseram, então, a designação de IgY.

Posteriormente, HADGE \& AMBROSIUS (1984) verificaram, através de radioimunoensaio, que anticorpos para a Ig de galinhas reagiam fortemente com a IgA de mamiferos. Estes resultados, associados a novos dados sobre os pesos moleculares destas Ig, levaram os autores a conclus/ào que as $\operatorname{IgY}$, predominantes no anti-soro de anfibios, répteis e aves, seriam precursoras das IgA de mamiferos. 


\section{MATERIAL E MÉTODOS}

\subsection{FONTE DE MATERIAL}

\subsubsection{Hemileia vastatrix}

Urediniosporos de $H$. vastatrix foram coletados em cafeeiros naturalmente infectados na Fazenda Santa Elisa (Instituto Agronômico de Campinas). Tubos plásticos de ultracentrífuga foram utilizados para a coleta de urediniosporos, atraves de raspagem cuidadosa de suas bordas sobre a superficie abaxial das folhas com lesões. Folhas com sinais de necrose ou de presença do hiperparasita Verticillium hemileiae Bouriquet (=Verticillium lecanii Zimm.) foram descartadas no processo de coleta. Os urediniosporos coletados foram passados por peneira Granutest $0,149 \mathrm{~mm}$ e armazenados em criotubos, dentro de tambor de nitrogènio líquido, até o momento de sua utilização.

Urediniosporos das raças fisiológicas II e III de $H$. vastatrix, portadoras dos genes de virulência vs e $\mathrm{vl} / \mathrm{v} 5$, respectivamente, foram coletados a partir de plantas de aproximadamente 1 ano de idade, inoculadas artificialmente em laboratório. A inoculação foi realizada através de aspersão de suspensão de urediniosporos em água destilada ( $2 \mathrm{mg} / \mathrm{ml}$ ), sobre a superficie abaxial das folhas, com aspersor de vidro propelido por nitrogênio gasoso. Em seguida, as plantas inoculadas foram transferidas para câmara úmida $\left(24 \pm 2^{\circ} \mathrm{C}\right.$ e umidade relativa acima de $\left.95 \%\right)$, onde permaneceram no escuro nos primeiros 2 dias e, passado este periodo, sob ciclos alternados de $12 \mathrm{~h}$ claro/escuro. A iluminação foi feita através de mistura de lâmpadas fluorescentes e incandescentes, fornecendo aproximadamente 1.200 lux. 30 a 40 dias após a inoculação, com o aparecimento dos primeiros sintomas, as plantas foram levadas para casa de vegetação onde, após a esporulação do fungo, procedeu-se a coleta de seus urediniosporos utilizando-se pincel e tubo plástico. Os urediniosporos coletados foram acondicionados em criotubos e armazenados em tambor de nitrogênio líquido. 


\subsubsection{Coffea spp.}

Plantas de C. arabica cv. Mundo Novo, portador do gene de resistência SH5 (grupo fisiológico E), foram utilizadas para a produção de urediniosporos da raça II de $H$. vastatrix assim como para a obtenção de antigenos utilizados na imunização dos animais e em testes sorológicos. Foram utilizadas plantas apresentando de 9 a 12 pares de folhas, com aproximadamente 1 ano de idade, desenvolvidas a partir de sementes obtidas junto a Seção de Genética do Instituto Agronômico de Campinas ou a Cooperativa dos Cafeicultores de Garça. A semeadura foi feita em areia contida em germinadores com tampa de vidro, onde permaneceram à temperatura ambiente até o aparecimento da folha primária. As plântulas foram então transplantadas para sacos plásticos de $11 \mathrm{~cm}$ de diâmetro por $20 \mathrm{~cm}$ de altura contendo terra vegetal/esterco de galinha/superfosfato simples/calcáreo calcitico/cloreto de potássio $(250 \mathrm{~V} / 2,5 \mathrm{~V} / 1.250 \mathrm{~g} / 250 \mathrm{~g} / 250 \mathrm{~g})(\mathrm{v} / \mathrm{v} / \mathrm{p} / \mathrm{p} / \mathrm{p})$. As plantas foram mantidas em casa de vegetação, à temperatura ambiente, até atingirem o tamanho apropriado, recebendo adubação mensal por irrigação com solução de sulfato de amônio / superfosfato simples e cloreto de potássio $(250 \mathrm{~g} / 500 \mathrm{~g} / 100 \mathrm{~g}$ em 1001 de água (p/p/p/v) para $3.000 \mathrm{mudas})$.

Plantas de C. arabica cv. Geisha, portador dos genes de resistência SH1 e SH5 (grupo fisiológico C), foram utilizadas para a produção de urediniosporos da raça III de $H$. vastatrix e para a obtenção de antígenos utilizados em testes sorológicos.

Plantas do cv. Sarchimor, portador dos genes de resistência SH6 e outros não determinados (grupo fisiológico $\mathrm{A}$ ), resultante do cruzamento entre Híbrido de Timor (C. arabica x C. canephora Pierre) e cv. Villa Sarchi (C. arabica), resistente a todas as raças conhecidas de $H$. vastatrix, foram utilizadas para a obtenção de antígenos utilizados em testes sorológicos.

As plantas pertencentes aos cultivares Geisha e Sarchimor foram obtidas por propagação vegetativa de ramos ortotrópicos. Essas plantas foram desenvolvidas em casa de vegetação, acondicionadas em sacos plásticos contendo o mesmo substrato que o utilizado para as plantas do $\mathrm{cv}$. Mundo Novo e recebendo a mesma adubação mensal. No momento de sua utilização, apresentavam entre 6 a 10 pares de folhas.

Folhas de cafeeiros pertencentes às espécies $C$. canephora (variedades Robusta e Kouillou), Coffea liberica Hiern, Coffea eugenioides Moore e Coffea congensis Froehner, foram obtidas a partir de plantas cultivadas na Fazenda 
Santa Elisa, pertencentes à Seção de Genética do Instituto Agronômico de Campinas.

\subsubsection{GALINHAS POEDEIRAS}

Galinhas poedeiras foram gentilmente cedidas pelas Granjas Ito (Sumaré - SP). As aves utilizadas tinham aproximadamente 1 ano de idade e peso ao redor de $1,5 \mathrm{~kg}$. Foram mantidas em gaiolas apropriadas à postura, com fornecimento diário de ração comercial e água.

\subsection{EXTRAÇÃO DOS ANTÍGENOS}

\subsubsection{Hemileia vastatrix}

Antigenos de urediniosporos de $H$. vastatrix foram obtidos pelo método do filtrado de esporos vivos (FEV), descrito por BERETTA et alii (1977). Suspensão de urediniosporos em água destilada $(20 \mathrm{mg} / \mathrm{ml})$ foi submetida a agitação por $2 \mathrm{~h}$ em placa agitadora magnética e, em seguida, passada por pré-filtro de fibra de vidro e membranas de nitrato de celulose com porosidades de $0,8 \mu \mathrm{m}, 0,44 \mu \mathrm{m}$ e $0,22 \mu \mathrm{m}$, sucessivamente. O filtrado resultante (FEV), foi liofilizado e conservado a $-20^{\circ} \mathrm{C} \mathrm{em}$ congelador.

\subsubsection{Coffea spp.}

Antigenos de cafeeiros foram extraídos a partir de folhas trituradas em almofariz resfriado com gelo seco. Ao pó resultante da trituração, foi adicionada a mesma quantidade em peso de polivinilpirrolidona (PVP) insolúvel (Sigma) e essa mistura foi despejada, na proporção de $0,1 \mathrm{~g}$ de folha por ml, sobre tampão fosfato de sódio $50 \mathrm{mM}(\mathrm{pH} \mathrm{7,5)}$ adicionado de ácido ascórbico na concentração de $0,1 \mathrm{M}$. Esta suspensão foi mantida sob agitação constante por $2 \mathrm{~h}$ em geladeira, com auxilio de placa agitadora magnética e, em seguida, passada por malha de náilon e centrifugada a 20.000 g por $20 \mathrm{~min}$ sob refrigeração $\left(4^{\circ} \mathrm{C}\right)$. $\mathrm{O}$ sobrenadante obtido foi passado por pré-filtro de fibra de vidro e submetido a precipitação com etanol à concentração final de $80 \% \mathrm{v} / \mathrm{v}$. Após $48 \mathrm{~h}$ em geladeira, o precipitado foi sedimentado através de centrifugação a 2.500 g por 20 min e retomado em solução de $\mathrm{NaCl} 0,14 \mathrm{M}$. A retomada do sedimento foi 
realizada com auxilio de aparelho agitador de ultra-som $(35 \mathrm{kHz})$ e os resíduos não solubilizados foram removidos por filtração em membrana de nitrato de celulose com porosidade de $0,22 \mu \mathrm{m}$

\subsection{IMUNIZAÇÃO DOS ANTMAIS:}

\subsubsection{COM ANTÍGENOS DE UREDINIOSPOROS DE RAÇAS DE $H$. vastatrix}

As galinhas poedeiras designadas pelas letras A e B foram imunizadas com antigenos extraídos de urediniosporos das raças II e III de $H$. vastatrix, respectivamente. Esses antígenos. obtidos pelo metodo do FEV, foram liofilizados e retomados em solução de $\mathrm{NaCl} 0,14 \mathrm{M}$. Para a raça II, a concentração de carboidratos e proteinas foi respectivamente de $0,36 \mathrm{Eq} \mathrm{mg}$ glicose $/ \mathrm{ml}$ e $1,00 \mathrm{Eq} \mathrm{mg} \mathrm{SAB} / \mathrm{ml}$ e para a raça III foi de $0,41 \mathrm{Eq} \mathrm{mg}$ glicose $/ \mathrm{ml}$ e $0,80 \mathrm{Eq} \mathrm{mg} \mathrm{SAB} / \mathrm{ml}$. Cada animal recebeu 3 injeções do antígeno, com intervalo de 2 semanas entre cada, sendo que cada uma delas constou de $100 \mu$ de antígeno emulsionado em igual volume de adjuvante completo de Freund. A galinha B recebeu uma $4^{\mathrm{a}}$ injeção do antígeno, 1 mês após a $3^{\mathrm{a}}$, devido a baixa produção de anticorpos verificada. Os antígenos foram injetados via sub-cutânea, na região axilar sob as asas das aves, alternando-se, a cada injeção, as axilas direita e esquerda.

\subsubsection{COM ANTIGENOS DE UREDINIOSPOROS DE $H$. vastatrix COLETADOS NO CAMPO}

Os anticorpos utilizados no estudo sobre os antígenos comuns foram produzidos pela galinha designada pela letra $C$, que para tal recebeu 6 injeções, com intervalo de uma semana entre cada, de antígeno extraido de urediniosporos coletados no campo em plantas naturalmente infectadas. Cada dose constou de $200 \mu \mathrm{l}$ de antígeno emulsionado em igual volume de adjuvante completo de Freund e foi aplicada por método idêntico ao descrito no ítem 3.3.1. O antígeno imunizante, obtido pelo método do $\mathrm{FEV}$, foi liofilizado e retomado em solução de $\mathrm{NaCl} 0,14 \mathrm{M}$ para uma concentração de $0,65 \mathrm{Eq} \mathrm{mg}$ glicose $/ \mathrm{ml}$ e 2,07 Eq mg SAB/ml. 


\subsubsection{COM ANTIGENOS DE FOLHAS DE CAFEEIRO CV. MUNDO NOVO}

O precipitado etanólico obtido a partir do extrato de folhas de cafeeiro $\mathrm{cv}$. Mundo Novo, foi utilizado como antigeno imunizante da galinha designada pela letra $\mathrm{D}$. A concentração do antígeno foi de $0,86 \mathrm{Eq} \mathrm{mg} \mathrm{glicose/ml} \mathrm{e} \mathrm{2,08} \mathrm{Eq} \mathrm{mg}$ $\mathrm{SAB} / \mathrm{ml}$. Foram aplicadas 8 injeções de $200 \mu \mathrm{l}$ do antigeno emulsionado em igual volume de adjuvante de Freund, com intervalo de 1 semana entre cada. Na primeira aplicação foi utilizado o adjuvante completo de Freund e nas demais, o incompleto. $O$ método de inoculação foi o mesmo descrito nos ítens anteriores.

\subsection{EXTRAÇÃO DOS ANTICORPOS A PARTIR DOS OVOS}

A extração dos anticorpos presentes nas gemas dos ovos foi realizada com base em metodologia descrita por POLSON et alii (1985). A figura 1 representa esquematicamente o método utilizado. Inicialmente, a gema foi separada da clara e lavada em água corrente de torneira. Com auxílio de um bastão de vidro, a membrana que envolve a gema foi rompida e o seu conteúdo coletado em proveta para a aferição de seu volume. Em seguida, ela foi despejada em um becker e diluída em 4 volumes de tampão fosfato $10 \mathrm{mM}(\mathrm{pH} 7,5)$ adicionado de $\mathrm{NaCl}$ a $0,1 \mathrm{M}$ e azida de sódio a $0,01 \% \mathrm{p} / \mathrm{v}$ (TFS). À gema diluida, foi acrescentado polietilenoglicol (PEG) 6.000 (Merck), obtendo-se uma concentração final de 3,5\% p/v. A mistura foi mantida sob agitação por alguns minutos até completa dissolução do PEG. Após centrifugação a $12.000 \mathrm{~g}$ por $15 \mathrm{~min}$, foi obtido um sedimento amarelo, um sobrenadante contendo os anticorpos e, sobre este, uma fina camada de gordura. Esse sobrenadante foi despejado em proveta, retendo-se a gordura em chumaço de algodão colocado no gargalo de um funil. Aferido o volume, o sobrenadante foi acrescido de PEG para uma concentração de $12 \% \mathrm{p} / \mathrm{v}$. O material foi agitado por alguns minutos até completa dissolução do PEG e, em seguida, centrifugado a $12.000 \mathrm{~g}$ por $15 \mathrm{~min}$, resultando em um sedimento branco contendo os anticorpos.

Com a finalidade de se eliminar contaminação pelo PEG presente junto aos anticorpos sedimentados, estes foram retomados em $10 \mathrm{ml}$ de TFS e reprecipitados pela adição de igual volume de etanol $50 \% \mathrm{v} / \mathrm{v}$, tomando-se o cuidado de manter o material em banho de gelo. Após nova centrifugação a $12.000 \mathrm{~g}$ por $15 \mathrm{~min}$, os 


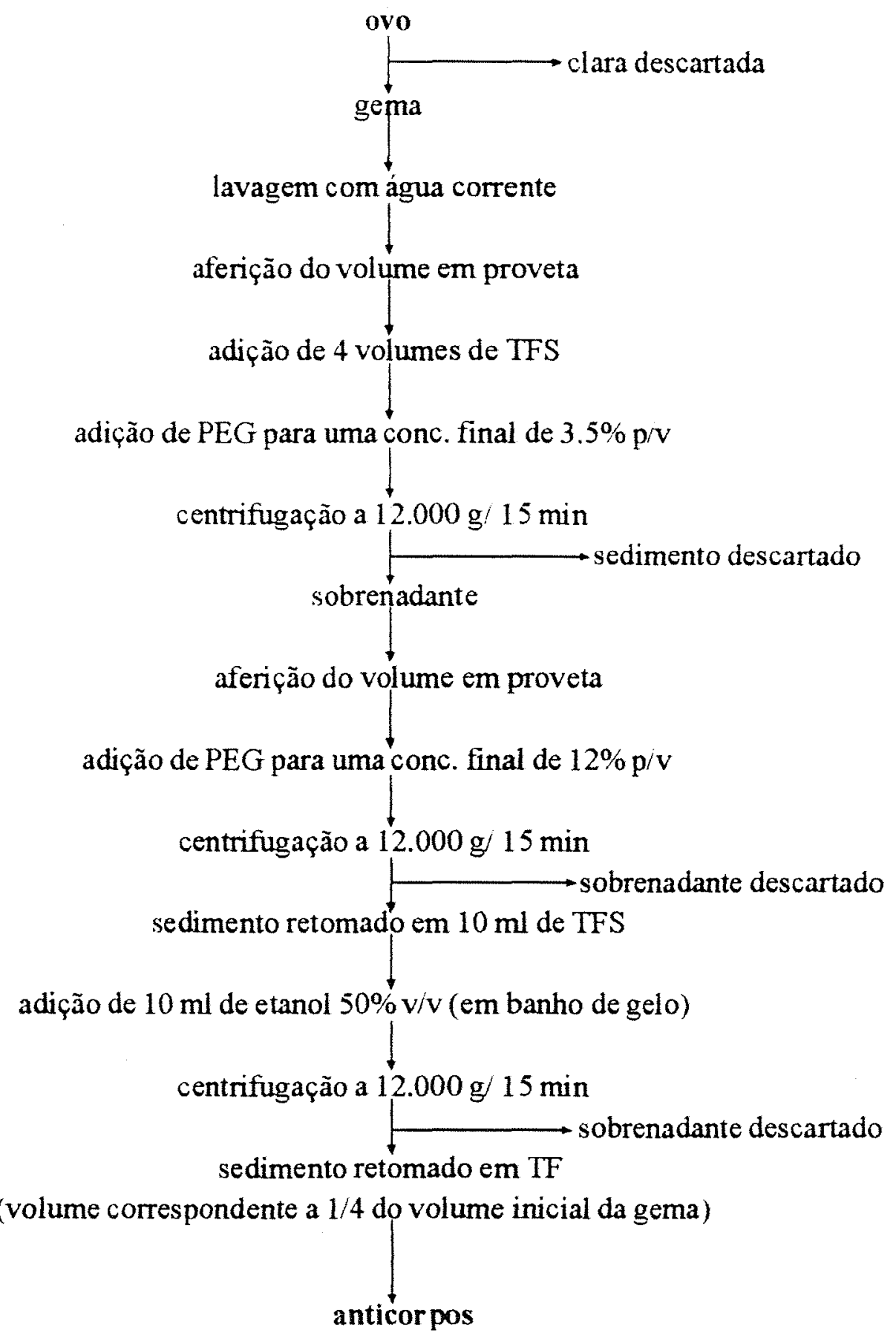

Figura 1. Método de extração de anticorpos a partir das gemas de ovos 
anticorpos sedimentados foram retomados em tampão fosfato $10 \mathrm{mM}(\mathrm{pH} 7,5)$ adicionado de azida de sódio a $0,01 \% \mathrm{p} / \mathrm{v}$, em volume correspondente a $1 / 4$ do volume inicial da gema. Os anticorpos foram, então, acondicionados em frascos de vidro e guardados em congelador $\left(-20^{\circ} \mathrm{C}\right)$.

\subsection{TESTES SOROLÓGICOS}

O teste sorológico utilizado foi o de dupla difusão em ágar (teste de Ouchterlony). Para tal, lâminas de microscopia $(2,5 \times 7,5 \mathrm{~cm})$ forma recobertas com 5 $\mathrm{ml}$ de ágar fundido $(1 \% \mathrm{p} / \mathrm{v}$ em tampão fosfato $10 \mathrm{mM}, \mathrm{pH} 7,5$, azida de sódio $0,1 \%$ p/v). Foram avaliadas duas concentrações de $\mathrm{NaCl}$ adicionado ao tampão: $0,14 \mathrm{M}$ e 1,4 M. Os orificios para anticorpos e antígenos foram perfurados com furador de $3 \mathrm{~mm}$ de diâmetro, em disposições variáveis conforme a necessidade, mas mantendo-se sempre uma distância de $4 \mathrm{~mm}$ entre as bordas dos orificios de anticorpos e antigenos. Em cada orificio foram aplicados $15 \mu \mathrm{l}$ do antígeno ou do anticorpo, conforme a necessidade. As lâminas foram mantidas em placas de Petri fechadas, contendo um chumaço de algodão umidecido em seu interior, por uma semana à temperatura ambiente. Após este período, foi realizada a lavagem das lâminas através de imersão destas em água destilada por um dia. Para a secagem, as lâminas foram recobertas com papel de filtro umidecido $e$ colocadas em estufa à temperatura aproximada de $37^{\circ} \mathrm{C}$, por um dia. A coloração das lâminas foi realizada com solução de negro de amido $0,1 \% \mathrm{p} / \mathrm{v}$ em etanol-ácido acético $(9: 1)$ e a lavagem, com a mesma mistura de etanol-ácido acético, sem o corante.

Para o registro fotográfico, os testes sorológicos foram realizados em placas de Petri de $7 \mathrm{~cm}$ de diâmetro preenchidas com $10 \mathrm{ml}$ de ágar fundido. Os orificios para anticorpos e antígenos foram perfurados com furador de $6 \mathrm{~mm}$ de diâmetro, em disposições variáveis conforme a necessidade, mas mantendo-se sempre uma distância de $7 \mathrm{~mm}$ entre as bordas dos orificios de anticorpos e antígenos. Os orificios foram preenchidos com $50 \mu \mathrm{l}$ dos anticorpos ou antigenos $\mathrm{e}$ as fotos foram tiradas após uma semana.

\subsection{TITULAÇÃO DOS ANTICORPOS}

O título dos anticorpos produzidos pela galinha A (imunizada com antígenos da raça II de $H$. vastatrix), foi verificado para os ovos postos até 53 dias após 
a última injeção, através de teste de dupla difusão em ágar. Os anticorpos extraidos de cada ovo foram diluídos em série, seguindo uma progressão geométrica de razão 2 , a partir de $1: 2$, em tampão fosfato (TF), e colocados em orificios no gel dispostos ao redor de um orifício central contendo o antígeno (FEV da raça II à concentração de 0,36 $\mathrm{Eq} \mathrm{mg} \mathrm{glicose/ml} \mathrm{e} 1,00 \mathrm{Eq} \mathrm{mg} \mathrm{SAB} / \mathrm{ml}$ ). Os orificios foram preenchidos com $15 \mu \mathrm{ldos}$ anticorpos ou do antígeno. A diluição maxima na qual ainda era visivel a linha de precipitação foi considerada como o título dos anticorpos do ovo do qual foram extraídos.

\subsection{ABSORÇÃO DOS ANTICORPOS}

Os anticorpos produzidos pelas galinhas A e B (Ac-HvII e AcHvIII), imunizadas com antigenos das raças II e III de $H$. vastatrix; respectivamente, foram absorvidos com os antigenos heterólogos, a fim de se verificar a especificidade dos mesmos. A absorção foi realizada misturando-se $0,5 \mathrm{ml}$ dos anticorpos com $0,5 \mathrm{ml}$ de antígeno heterólogo (Ac-HvII com FEV da raça II e Ac-HvIII com FEV da raça II). Após incubação à $37^{\circ} \mathrm{C}$ por $1 \mathrm{~h}$, os anticorpos absorvido foram avaliados, em teste de dupla difusão em ágar, quanto à reação com os antígenos homólogos.

\subsection{QUANTIFICAÇÃO DOS ANTÍGENOS COMUNS}

A quantificação dos antígenos comuns presentes nas frações obtidas nas etapas de sua purificação, foi realizada através de teste de dupla difusão em ảgar, de maneira similar à utilizada para a titulação dos anticorpos. As frações contendo os antígenos comuns foram diluídas em série, seguindo uma progressão geométrica de razão 2, a partir de $1: 2$, e colocadas em orificios no gel, ao redor de um orificio central no qual eram aplicados os anticorpos. Os orificios periféricos foram preenchidos com 15 $\mu l$ das diluições dos antígenos e o orificio central, com $15 \mu \mathrm{l}$ dos anticorpos produzidos pela galinha C. A dilução máxima na qual ainda era visivel a linha de precipitação, foi utilizada como parâmetro de comparação da concentração dos antígenos comuns presentes nas diferentes frações. 


\subsection{QUANTIFICAÇÃO DE PROTEINAS E CARBOIDRATOS}

Para a quantificação das proteinas presentes nas diferentes amostras estudadas, foi utilizado o teste de Lowry (LOWRY et alii, 1951), empregando a soroalbumina bovina $(\mathrm{SAB})$ como referência.

A quantificação de carboidratos foi efetuada através de teste de antrona (DISCHE, 1962), utilizando a glicose como referência.

\subsection{PURIFICAÇÃO DOS ANTIGENOS COMUNS PRESENTES NO EXTRATO FOLIAR DE CAFEEIROS CV. MUNDO NOVO}

\subsubsection{PRECIPITAÇÃO ETANÓLICA}

A partir de $30 \mathrm{~g}$ de folhas de cafeeiro $\mathrm{cv}$. Mundo Novo trituradas em almofariz resfriado com gelo seco, foram obtidos $260 \mathrm{ml}$ de extrato bruto, utilizandose método descrito no ítem 3.2.2. Através de ultrafiltração em membrana Amicon YM 10 (permeável à moléculas menores que 10.000 daltons), o volume do extrato bruto foi reduzido para $60 \mathrm{ml}$ sendo designado por MN-EB. Uma alíquota de $5 \mathrm{ml}$ do MN-EB foi exaustivamente dialisada contra água destilada e analisada quanto ao conteúdo de carboidratos, proteínas e antígenos comuns. Os $55 \mathrm{ml}$ restantes foram adicionados de $220 \mathrm{ml}$ de etanol previamente resfriados em congelador $\left(-20^{\circ} \mathrm{C}\right)$. A adição do etanol foi realizada lentamente, sob agitação constante em placa agitadora magnética e em banho de gelo. Após $48 \mathrm{~h}$ em geladeira $\left(4^{\circ} \mathrm{C}\right)$, a suspensão foi submetida à centrifugação a $2.500 \mathrm{~g}$ por $20 \mathrm{~min}$.

O sobrenadante obtido, foi decantado e submetido à secagem em rotoevaporador à $40^{\circ} \mathrm{C}$, resultando em um resíduo que foi retomado em $10 \mathrm{ml}$ de água destilada e dialisado exaustivamente contra a mesma. Em seguida, o volume do sobrenadante foi acertado para $55 \mathrm{ml}$ e avaliado quanto ao seu conteúdo de proteínas, carboidratos e antigenos comuns. Esta fração foi denominada de MN-Sn80.

O sedimento foi retomado em $10 \mathrm{ml}$ de água destilada, com auxilio de agitador de ultra-som $(35 \mathrm{kHz})$ e dialisado exaustivamente contra a mesma. Em seguida, o material foi filtrado em membrana $0,22 \mu \mathrm{m}$ e o seu volume acertado para 55 $\mathrm{ml}$. Essa fração foi denominada de $\mathrm{MN}-\mathrm{Sd} 80$. Uma alíquota de $5 \mathrm{ml}$ do $\mathrm{MN}-\mathrm{Sd} 80$ foi separada para quantificação de proteínas, carboidratos e antígenos comuns e os $50 \mathrm{ml}$ 
restantes foram submetidos a secagem em rotoevaporador à $40^{\circ} \mathrm{C}$. O residuo obtido foi retomado em $4 \mathrm{ml}$ de tampão Tris- $\mathrm{HCl} 10 \mathrm{mM}(\mathrm{pH} 8,0)$, para realização da cromatografia de troca iônica.

\subsubsection{CROMATOGRAFIA DE TROCA IONNICA EM DEAE SEPHADEX A-25}

Para o preparo da coluna, 6,5 g de DEAE Sephadex A-25 foram embebidos em $50 \mathrm{ml}$ de tampão Tris- $\mathrm{HCl} 10 \mathrm{mM}$ (pH 8,0), através de aquecimento em banho-maria fervente por $1 \mathrm{~h}$. Após o embebimento, a solução tampão foi trocada repetidas vezes até a estabilização do $\mathrm{pH}$ no valor 8,0 . Em seguida. o gel foi desgaseificado e empacotado em coluna de vidro $(1,5 \times 25 \mathrm{~cm})$, obtendo-se $33.5 \mathrm{ml}$ de gel sedimentado. A coluna foi estabilizada através da passagem de $100 \mathrm{ml}$ de tampão Tris- $\mathrm{HCl}$. A taxa de fluxo, ajustada para $20 \mathrm{ml} / \mathrm{h}$, foi controlada através de bomba peristaltica $(\mathrm{LKB})$ e as frações, de $6 \mathrm{ml}$ cada, foram coletadas em aparelho coletor automático (LKB).

Os $4 \mathrm{ml}$ correspondentes ao MN-Sd80 concentrado, foram cuidadosamente aplicados sobre o leito da coluna. As 6 primeiras frações foram eluídas em tampăo Tris- $\mathrm{HCl}$ e da $7^{\mathrm{a}}$ fraçăo até a $24^{\mathrm{a}}$, foram elú́das com gradiente crescente de $\mathrm{NaCl}(0$ a $0,8 \mathrm{M})$. As 6 últimas frações $\left(25^{\circ}\right.$ a $\left.30^{a}\right)$ foram elúdas em tampão Tris- $\mathrm{HCl}$ $\operatorname{com~} \mathrm{NaCl}$ à $0,8 \mathrm{M}$.

As frações foram avaliadas quanto ao conteúdo de proteínas, carboidratos e antígenos comuns e aquelas que se mostraram positivas para a presença destes últimos foram reunidas. O volume destas frações agrupadas foi reduzido a aproximadamente $15 \mathrm{ml}$, em rotoevaporador à temperatura de $40^{\circ} \mathrm{C}$, realizando-se em seguida, exaustiva diálise do material contra água destilada. Após a diálise, o volume da amostra foi acertado para $50 \mathrm{ml}$ com água destilada, sendo então designada de MN-TI. Uma alíquota de $5 \mathrm{ml}$ do $\mathrm{MN}-\mathrm{TI}$ foi separada para a quantificação de proteínas. carboidratos e antígenos comuns e os $45 \mathrm{ml}$ restantes foram submetidos a secagem em rotoevaporador a $40^{\circ} \mathrm{C}$. O residuo obtido foi retomado em $2 \mathrm{ml}$ de água destilada, a fim de se realizar a filtração em gel de Sephadex. 


\subsubsection{FILTRAÇÃO EM GEL DE SEPHADEX G-100}

Para o preparo da coluna, 4,7 g de Sephadex G-100 foram embebidos em $100 \mathrm{ml}$ de água destilada, através de aquecimento em banho-maria fervente por $5 \mathrm{~h}$. Após resfriamento e desgaseificação do gel, este foi empacotado em coluna de vidro $(1,6 \times 40 \mathrm{~cm})$, obtendo-se $70 \mathrm{ml}$ de gel sedimentado. A coluna foi estabilizada através da passagem de $120 \mathrm{ml}$ de água destilada.

Para o cálculo experimental do volume externo (Vo) e volume interno (Vi), foram aplicados à coluna $2 \mathrm{ml}$ de amostra contendo $4 \mathrm{mg}$ de Blue Dextran 2.000 (Pharmacia) e $0.5 \mathrm{mg}$ de glicose. A taxa de fluxo, ajustada para $12 \mathrm{ml} / \mathrm{h}$, foi controlada através de bomba peristaltica (LKB) e o eluato coletado em coletor automático (LKB). Foram coletadas 25 frações de $4 \mathrm{ml}$ cada. as quais foram avaliadas quanto a absorbância em $340 \mathrm{~nm}$ (para a deteç̧ão do Blue Dextran) e quanto a presença de glicose, através de teste de antrona.

Uma vez determinados os Vo e $\mathrm{Vi}, 2 \mathrm{ml}$ correspondentes ao $\mathrm{MN}$ TI foram cuidadosamente aplicados sobre o leito da coluna e eluidos com água destilada em 25 frações de $4 \mathrm{ml}$ cada. A taxa de fluxo utilizada foi de $8 \mathrm{ml} / \mathrm{h}$. As frações eluídas foram avaliadas quanto a presença de proteínas, carboidratos e antígenos comuns.

As frações positivas para a presença dos antigenos comuns foram reunidas e o seu volume acertado para $45 \mathrm{ml}$, sendo denominadas de MN-GF. O conteúdo em proteinas, carboidratos e antigenos comuns do MN-GF foi avaliado visando a comparação com as demais frações resultantes da precipitação etanólica e da cromatografia de troca iônica.

\subsubsection{AVALIAÇÃO DA EFICIENCLA DOS PROCESSOS UTILIZADOS NA PURIFICAÇÃO DOS ANTÍGENOS COMUNS}

O grau de pureza dos antígenos comuns presentes nas frações provenientes da precipitação etanólica. da cromatografia de troca iônica e da filtração em gel, foi avaliado através do cálculo das concentrações mínimas necessárias (de proteínas e carboidratos) para a formação de linha de precipitação em teste de dupla difusão em ágar. Esse cálculo consistiu na divisão dos valores das concentrações de proteínas ou carboidratos de cada fração, pelo fator de diluição máxima para o qual ainda se observava a formação de linha de precipitação. O resultado desta divisão corresponde às 
concentrações de proteínas de carboidratos presentes na diluição máxima. Quanto menor a concentração mínima necessária, maior o grau de pureza dos antígenos comuns.

\subsection{ESTUDOS SOBRE A NATUREZA QUÍMICA DOS ANTÍGENOS COMUNS}

\subsubsection{TRATAMENTO COM METAPERIODATO DE SÓDIO}

A metodologia utilizada para o tratamento das amostras com o metaperiodato de sódio foi baseada em SPIRO (1972). Alíquotas de $4 \mathrm{ml}$ do MN-GF, contendo $28 \mathrm{Eq} \mu \mathrm{g}$ glicose totais, foram liofilizadas e, em seguida. dissolvidas em $2 \mathrm{ml}$

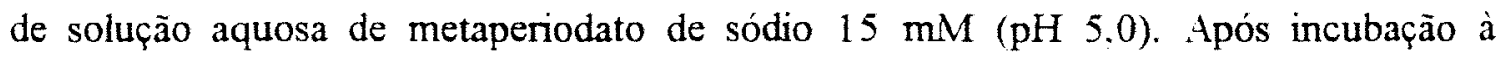
temperatura ambiente e no escuro, por 2 dias. o excesso de metaperiodato foi consumido pela adição de $0.2 \mathrm{ml}$ de etileno glicol, a cada alíquota. Como controle, uma das alíquotas do MN-GF foi dissolvida em solução de metaperiodato tratado previamente com o etileno glicol. Passados os 2 dias, as amostras foram dialisadas exaustivamente contra água destilada e examinadas quanto a presença de antígenos comuns através de teste sorológico.

\subsubsection{TRATAMENTO COM PRONASE}

Amostras do MN-GF foram submetidas ao tratamento com pronase, segundo metodologia descrita por SPIRO (1972) e KOGEL et alii (1988).

Alíquotas de $4 \mathrm{ml}$ do $\mathrm{MN}$-GF, contendo $0,25 \mathrm{Eq} \mathrm{mg} \mathrm{SAB}$ totais cada, foram liofilizadas e em seguida dissolvidas em $1 \mathrm{ml}$ de tampão Tris- $\mathrm{HCl} 50 \mathrm{mM}$ ( $\mathrm{pH} 7,8$ ) acrescido de $\mathrm{CaCl}_{2} 1 \mathrm{mM}$. As alíquotas foram adicionadas de $25 \mu 1$ de solução de pronase a $0,01 \%$ p/v no mesmo tampão, e incubadas à $37^{\circ} \mathrm{C}$. Após $48 \mathrm{~h}$, uma das alíquotas recebeu mais $25 \mathrm{ml}$ da solução da enzima. Passadas $96 \mathrm{~h}$, desde o início do tratamento, as amostras foram submetidas a banho-maria fervente por $15 \mathrm{~min} e$ centrifugadas a $5.000 \mathrm{~g}$ por $15 \mathrm{~min}$. O sedimento foi descartado e o sobrenadante foi examinado quanto a presença de antígenos comuns. $O$ controle consistiu de alíquota do MN-GF que sofreu o mesmo processo das demais, exceto que não foi adicionada da solução da pronase. 


\subsubsection{TRATAMENTO TERMICO}

Alíquotas do MN-GF foram submetidas, independentemente, aos seguintes tratamentos térmicos: banho-maria fervente por 30 e 60 min e autoclavagem à $120^{\circ} \mathrm{C}$ por $30 \mathrm{~min}$. Após os tratamentos, as alíquotas foram examinadas. através de teste sorológico, quanto a presença de antigenos comuns. 


\section{RESULTADOS}

\subsection{TITULAÇÃO DOS ANTICORPOS PRODUZIDOS PELA GALINHA A}

O título dos anticorpos produzidos pela galinha A. imunizada contra antígenos da raça II de $H$. vastatrix, estão expressos na Figura 2. Os ovos postos logo após a $3^{\mathrm{a}}$ injeção já apresentavam anticorpos com reação ao antígeno. Foi verificado um aumento gradativo no título até o $18^{\circ}$ dia quando o título atingiu o valor máximo de 1 : 32. Do $18^{\circ}$ ao $41^{\circ}$ dia o título foi mantido no seu valor máximo, com pequenas oscilações, e em seguida, houve uma queda para o valor de $1: 8$, permanecendo ao redor deste valor até o último ovo analisado, posto no $53^{\circ}$ dia após a última injeção.

A utilização de tampão adicionado de $\mathrm{NaCl}$ na concentração de 1,4 M, para a confecção das lâminas de ágar, proporcionou linhas de precipitação mais intensas que aquelas formadas na presença do sal à concentração de $0,14 \mathrm{M}$ (Figuras $3 \mathrm{e}$ 4). Em decorrência disso, os demais testes sorológicos realizados no presente trabalho foram feitos em ágar confeccionado com o $\mathrm{NaCl}$ na concentração mais elevada.

\subsection{COMPARAÇÕES SOROLÓGICAS}

\subsubsection{ANTICORPOS PARA ANTIGGENOS DE RAÇAS DE H. vastatrix}

Os anticorpos produzidos pelas galinhas $\mathrm{A}$ e $\mathrm{B}$, imunizadas com antígenos das raças II e III de H. vastatrix, respectivamente (Ac-HvII e Ac-HvIII), resultaram em até duas linhas de precipitação na reação com seus antígenos homólogos. Esses anticorpos não apresentaram especificidade para raça pois reagiram igualmente com antígeno heterólogo, formando linhas de precipitação com as bordas completamente coalescidas (Figuras 4 e 5). A inespecificidade destes anticorpos foi verificada tanto para aqueles extraidos de ovos postos na $1^{a}$ semana após a última imunização como para aqueles extraídos de ovos postos nas semanas posteriores. Não foi detectada reação de 


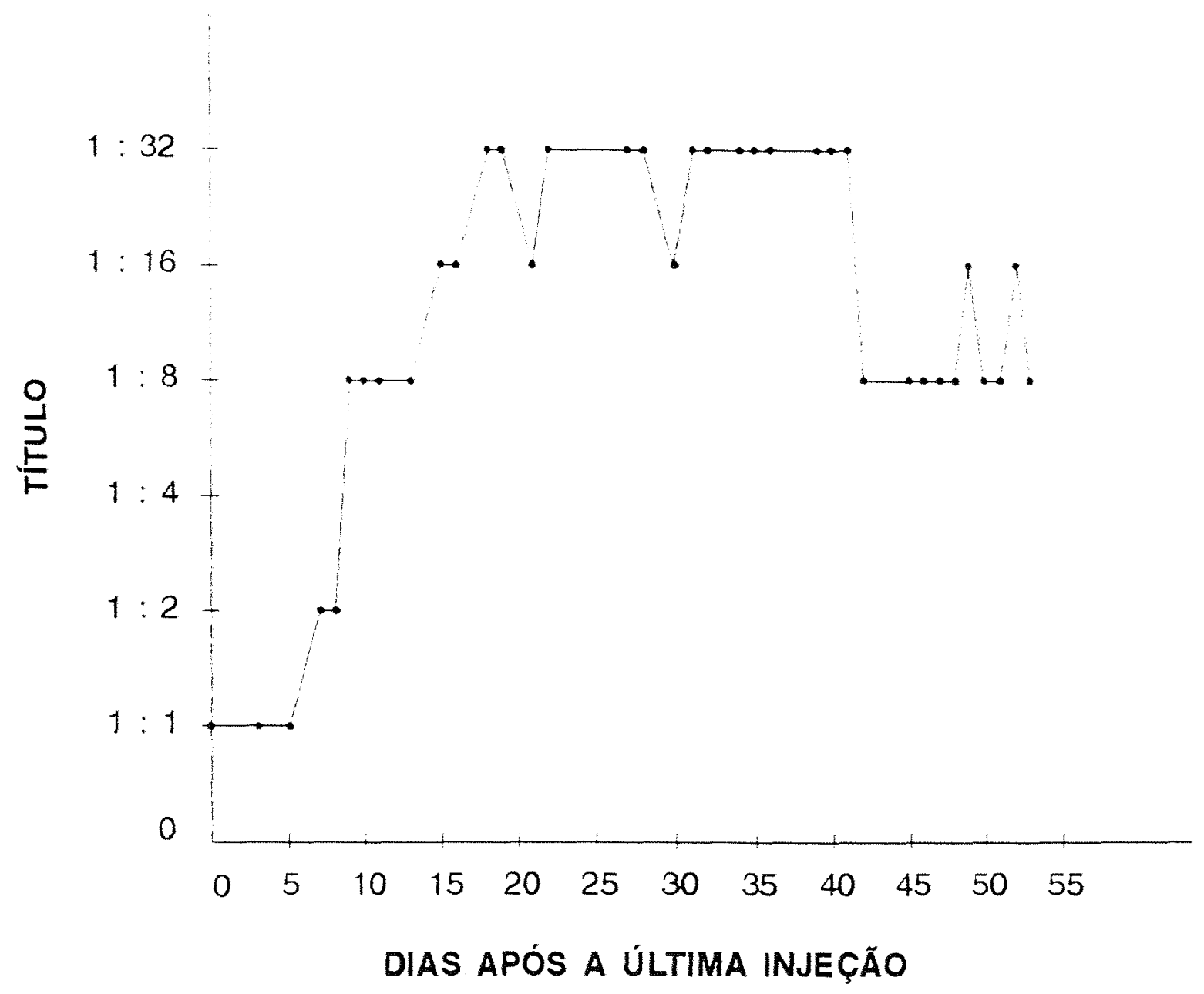

Figura 2. Titulação dos anticorpos produzidos pela galinha $A$

O título dos anticorpos foi verificado através de teste de dupla difusão em ágar em lâmina de microscopia. Os valores correspondem à diluição máxima na qual ainda era visivel a linha de precipitação. 


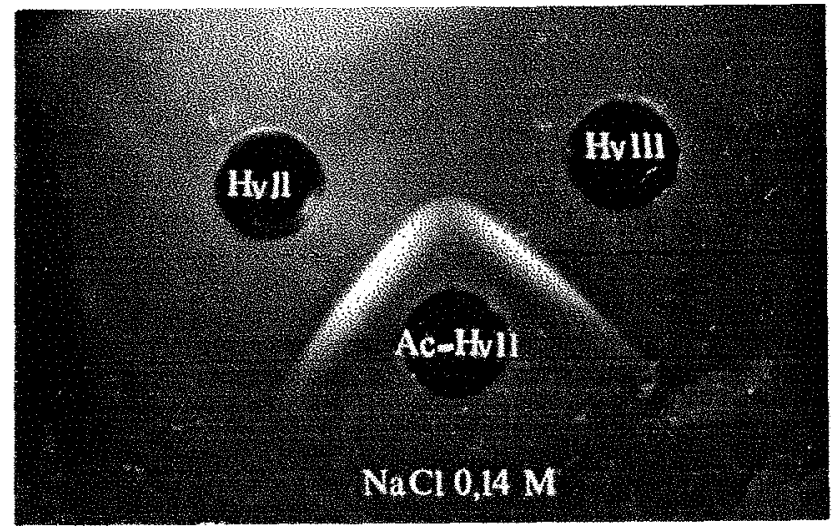

Figura 3. Reação sorológica em ágar contendo $\mathrm{NaCl}$ à concentração de $0,14 \mathrm{M}$.

Ac = anticorpos para antigenos da raça II de H. vastatrix (Ac-HvII)

II = FEV da raça II de $H$. vastatrix (reação homóloga)

III = FEV da raça III de H. vastatrix (reação heteróloga)

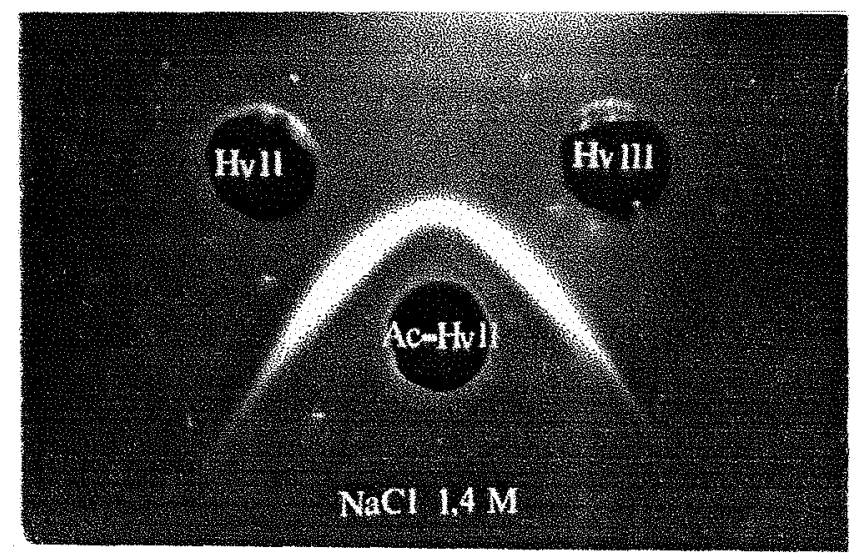

Figura 4. Comparação sorológica entre raças II e III de $H$. vastatrix através de anticorpos para raça $\Pi$.

$A c=$ anticorpos para antígenos da raça II de $H$. vastatrix (Ac-HvII)

II = FEV da raça $\Pi$ de $H$. vastatrix (reação homóloga)

III = FEV da raça III de $H$. vastatrix (reação heteróloga)

Gel confeccionado com $\mathrm{NaCl}$ à concentração de $1,4 \mathrm{M}$. 


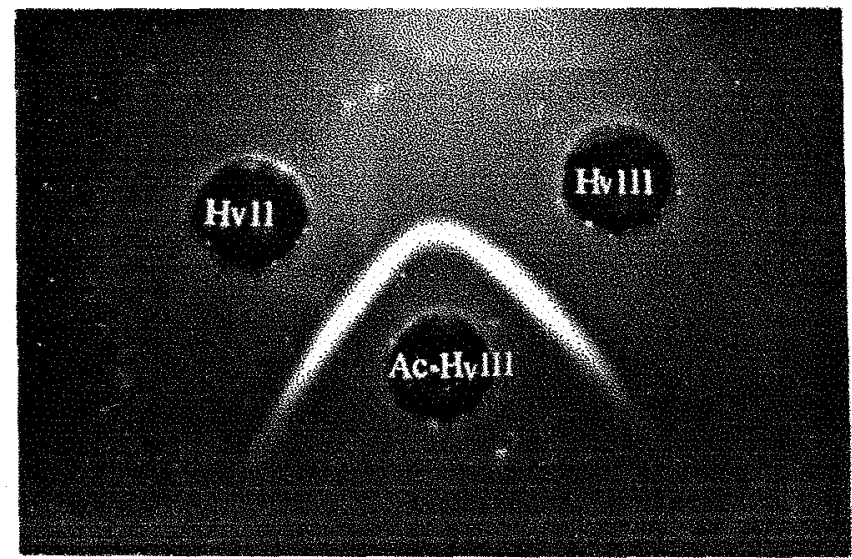

Figura 5. Comparação sorológica entre raças II e III de $H$. vastatrix através de anticorpos para raça III.

$A c=$ anticorpos para antígenos da raça III de H. vastatrix (Ac-HvIII)

II = FEV da raça II de H. vastatrix (reação heteróloga)

III = FEV da raça III de $H$. vastatrix (reação homóloga)

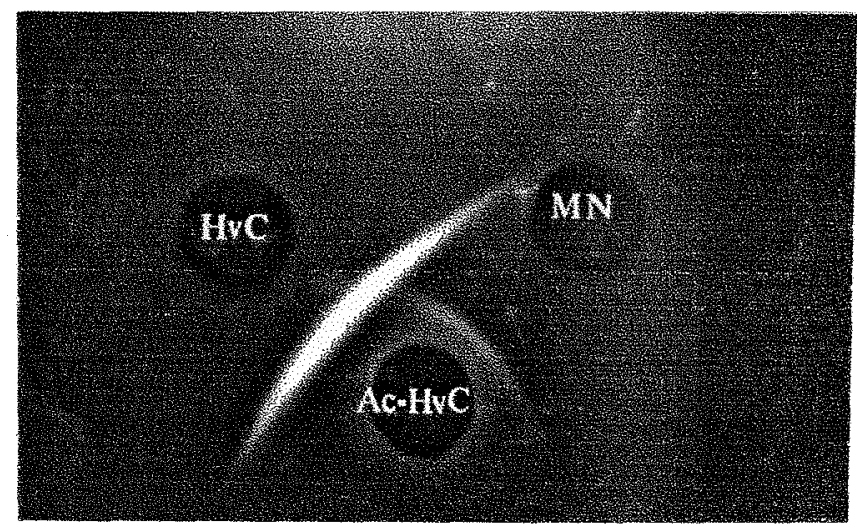

Figura 6. Reação dos anticorpos para $H$. vastatrix coletada no campo, com antígenos homólogo e de cafeeiro cv. Mundo Novo.

$A c=$ anticorpos para antígenos de $H$. vastatrix coletada no campo

$\mathrm{Hv}=\mathrm{FEV}$ de $H$. vastatrix coletada no campo (reação homóloga)

$\mathrm{MN}=$ extrato de folhas de cafeeiro cv. Mundo Novo (reação heteróloga) 
qualquer destes anticorpos com antígenos extraidos de cafeeiro. Anticorpos extraidos de ovo posto previamente à imunização, não reagiram com qualquer desses antígenos.

\subsubsection{ANTICORPOS PARA ANTIGENOS DE H. vastatrix COLETADA NO CAMPO}

Anticorpos produzidos pela galinha $\mathrm{C}$, imunizada com antígenos de urediniosporos de $H$. vastatrix coletados no campo, designados por Ac-HvC, apresentaram reação tanto com antígenos homólogos como com antígenos extraidos de cafeeiros pertencentes a diversas espécies do gênero Coffea (Figuras 6 e 7).

$\mathrm{Na}$ reação homóloga, foi observada a formação de pelo menos 3 linhas de precipitação. enquanto que na heteróloga, com antigenos de cafeeiros. somente uma linha tênue, próxima ao poço dos anticorpos, pôde ser observada (Figura 6).

Anticorpos extraidos de ovo posto pela galinha $\mathrm{C}$, previamente à imunização não reagiram com qualquer destes antígenos.

\subsubsection{ANTICORPOS PARA ANTIGENOS DE CAFEEIRO CV. MUNDO NOVO}

Os anticorpos produzidos pela galinha $\mathrm{D}$ ( Ac-MN) apresentaram reação intensa com antígeno homólogo, resultando na formação de pelo menos 3 linhas de precipitação (Figura 8). Porém, estes anticorpos não detectaram antígenos comuns na reação com antígenos do fungo (Figura 8).

Anticorpos extraídos de ovo posto pela galinha $D$, previamente à imunização não reagiram com qualquer destes antígenos.

\subsection{PURIFICAÇÃO DOS ANTÍGENOS COMUNS PRESENTES NO EX- TRATO FOLIAR DE CAFEEIRO CV. MUNDO NOVO}

\subsubsection{PRECIPITAÇÃO ETANÓLICA}

As concentrações de proteinas e carboidratos presentes no extrato bruto (MN-EB), sobrenadante (MN-Sn80) e sedimento (MN-Sd80) estão expressos na Tabela 2. 


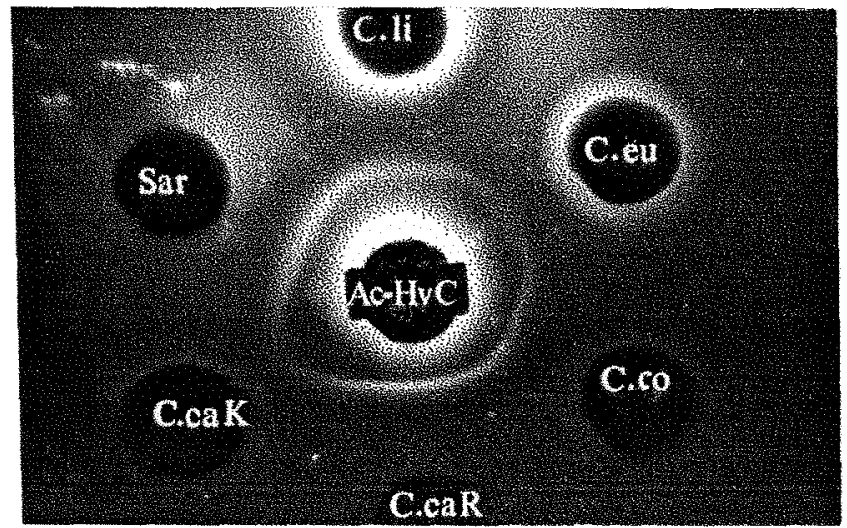

Figura 7. Detecção de antigenos comuns a $H$. vastatrix em diversas espécies de cafeeiro. Ac $=$ anticorpos para $H$. vastatrix coletada no campo

$1=C$. liberica $\quad 2=C$. eugenioides $3=C$. congensis

$4=C$. canephora (Robusta) $\quad 5=C$. canephora (Kouillou)

$6=$ Híbrido Sarchimor

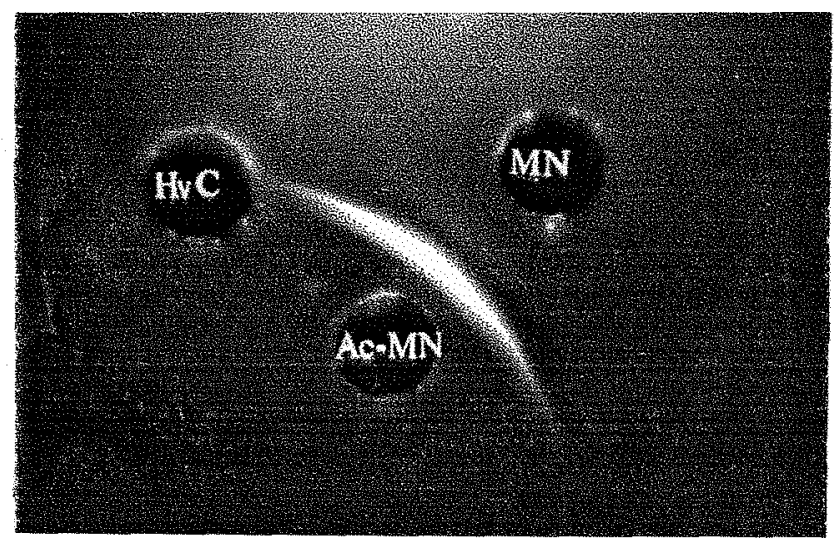

Figura 8. Reação dos anticorpos para cafeeiro cv. Mundo Novo, com antigenos homólo-go e de $H$. vastatrix.

$A c=$ anticorpos para antigenos de cafeeiro cv. Mundo Novo

$\mathrm{HvC}=\mathrm{FEV}$ de $H$. vastatrix coletada no campo (reação heteróloga)

$\mathrm{MN}=$ extrato de cafeeiro cv. Mundo Novo (reação homóloga) 
Tabela 2. Concentrações de proteinas e carboidratos do sobrenadante e sedimento provenientes da precipitação etanólica do extrato bruto de $C$. arabica $\mathrm{cv}$. Mundo Novol.

\begin{tabular}{|c|c|c|c|c|}
\hline FRAÇOัES & $\begin{array}{l}\text { PROTEINAS }^{2} \\
(\mathrm{Eq} \mu \mathrm{g} \text { SAB } \mathrm{ml})\end{array}$ & $\begin{array}{c}\text { CARBOIDRATOS }^{3} \\
(\text { Eq } \mu \mathrm{g} g l i c o s e / m l)\end{array}$ & $\begin{array}{c}\text { PROTEINAS } \\
\%\end{array}$ & $\begin{array}{l}\text { CARBOIDRATOS } \\
(\%)\end{array}$ \\
\hline $\mathrm{MN}-\mathrm{EB}$ & 1.039 & 209 & - & - \\
\hline $\mathrm{MN}-\mathrm{Sn} 80$ & 219 & 32 & 37,76 & 17,88 \\
\hline $\mathrm{MN}-\mathrm{Sd} 80$ & 361 & 147 & 62,24 & 82,12 \\
\hline $\mathrm{MN}-\mathrm{Sn} 80+\mathrm{MN}-\mathrm{Sd} 80$ & 580 & 179 & - & - \\
\hline$\%$ RECUPERAÇÃO 5 & 55,82 & 85,65 & - & - \\
\hline
\end{tabular}

1. Os resultados apresentados representam a média de dois experimentos com 3 réplicas cada.

2. Concentração de proteínas determinada pelo teste de Lowry.

3. Concentração de carboidratos determinada pelo teste de antrona.

4. \% de proteinas e carboidratos de cada fração em relação ao total recuperado.

5. $M N-S n 80+M N-S d 80 \times 100$

$\mathrm{MN}-\mathrm{EB}$ 
$O$ total de proteínas, somados o MN-Sn80 e MN-Sd80, corresponderam a somente $55,82 \%$ do total presente no MN-EB, indicando baixa taxa de recuperação. Com relação aos carboidratos. a taxa de recuperação foi maior, atingindo $85,65 \%$.

Do total de proteinas recuperadas, a maior parte $(62.24 \%)$ foi detectada no sedimento. Quanto aos carboidratos, o percentual presente no sedimento foi mais elevado ainda $(82,12 \%)$.

Os antigenos comuns foram detectados somente no EB-MN e no $\mathrm{MN}-\mathrm{Sd80}$. Em ambas as frações, a diluição máxima na qual esses antígenos puderam ser detectados foi de $1: 128$.

\subsubsection{CROMATOGRAFIA DE TROCA IÒNICA}

As concentrações de proteinas e carboidratos detectadas nas frações eluídas da coluna estão expressas na Figura 9. Os totais de proteínas e carboidratos presentes na amostra de MN-Sd80 aplicada à coluna foram de, respectivamente, 18,05 Eq mg SAB e 7,35 Eq mg glicose.

Em relação às proteínas, foi verificado um pequeno pico na fração 2 , eluída em tampão, e um pico maior, com máximo na fração 14 , eluída no gradiente de $\mathrm{NaCl}$.

Quanto aos carboidratos, um pico elevado foi detectado na fração 2 e outro menor, com o máximo na fração 10 , foi eluído sob ação do gradiente de $\mathrm{NaCl}$.

A Figura 10 mostra os resultados da quantificação dos antigenos comuns presentes nas frações eluidas da coluna. Esses antígenos foram detectados em concentrações decrescentes, da fração 14 até a última. Para a fração 14, a detecção foi possível em diluições de até $1: 256$ e para a última fração, em diluições de até $1: 2$. Esses resultados indicam um comportamento heterogêneo dos antigenos comuns quanto a afinidade pelo trocador aniônico, pois foram eluidos ao longo de quase todo o gradiente de $\mathrm{NaCl}$.

O pico de concentração dos antigenos comuns coincidiu com o das proteinas (fração 14), porém os antigenos foram detectados, também, em fraçōes nas quais não se detectaram proteínas (frações 21 a 30 ). 
$\infty$ (ן)

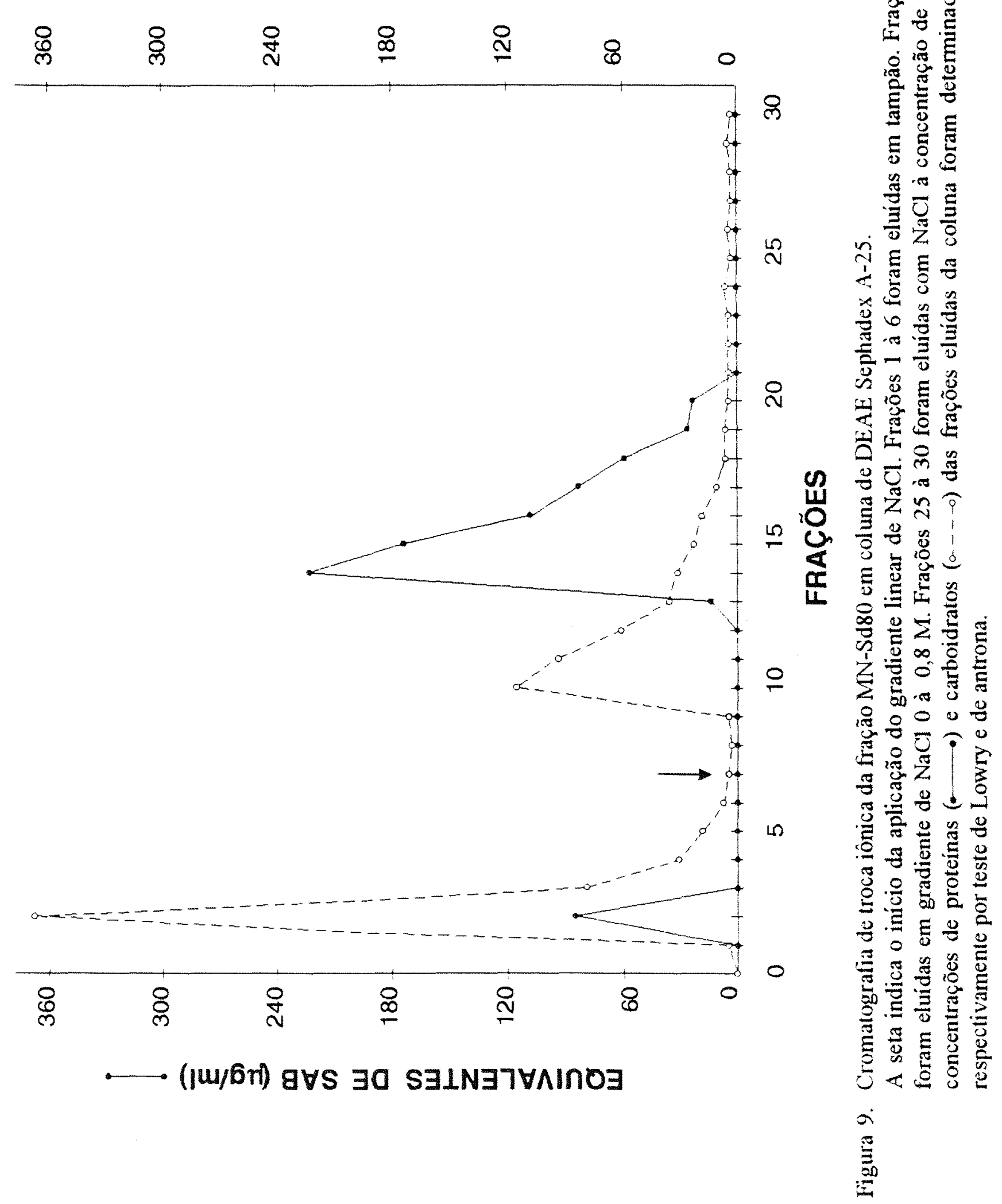




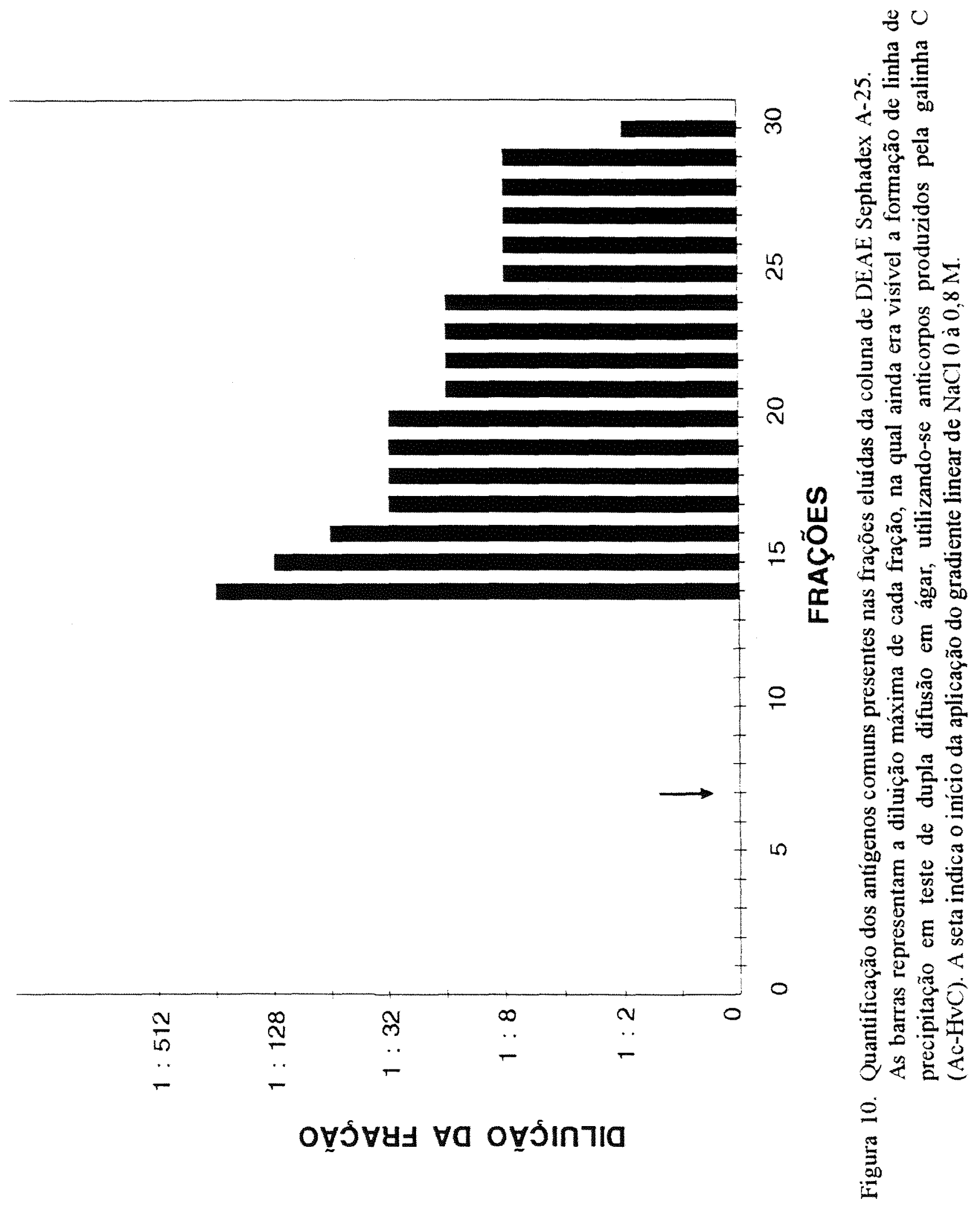




\subsubsection{FILTRAÇÃO EM GEL DE SEPHADEX G-100}

A Figura 11 mostra o resultado da determinação experimental dos volumes externo (Vo) e interno (Vi), obtidos, respectivamente, com o Blue Dextran e a glicose. Através do gráfico chegou-se aos valores de $30,5 \mathrm{ml}$ para o Vo e $72,0 \mathrm{ml}$ para o Vi.

A amostra proveniente da cromatografia de troca iônica, MN-TI (4,03 Eq mg SAB e 0,35 Eq mg glicose totais), foi aplicada à coluna de Sephadex G-100 e as concentrações de proteínas e carboidratos presentes nas frações eluídas estão apresentados na Figura 12.

Foi verificado um pico de eluição das proteinas na fração 8 e. de carboidratos. na fração 7, ambos próximos ao volume externo. No volume interno não foram detectadas proteinas $e$ os carboidratos foram detectados em pequenas concentrações.

A Figura 13 apresenta os resultados da quantificação dos antigenos comuns presentes nas frações eluídas da coluna. Esses antígenos estavam presentes em várias frações, desde o Vo até o Vi. O máximo foi detectado na fração 8, apresentando decréscimo gradual nas frações subsequentes. Estes resultados indicam uma grande heterogeneidade dos antigenos comuns quanto à dimensão de suas moléculas, porém com predominância na faixa de peso molecular igual ou maior que 150.000 daltons (próximo ao Vo).

Foi observada, novamente, uma coincidência nos picos de eluição das proteínas e dos antígenos comuns, porém, nas frações correspondentes ao volume interno, somente os antígenos puderam ser detectados.

\subsubsection{COMPARAÇÃO DAS FRAÇÕFS PROVENIENTES DO EXTRATO DE CAFEEIRO CV. MUNDO NOVO, QUANTO AO GRAU DE PUREZA DOS ANTÍGENOS COMUNS}

A tabela 3 contem os dados referentes ao conteúdo em proteínas e carboidratos do extrato foliar bruto de cafeeiro cV. Mundo Novo (MN-EB) e das frações dele provenientes (MN-Sd80, MN-TI e MN-GF). Constam também da tabela, a diluição máxima na qual ainda ocorria a formação de linha de precipitação e a concentração mínima necessária para a detecção dos antígenos comuns, obtida pela divisão do 


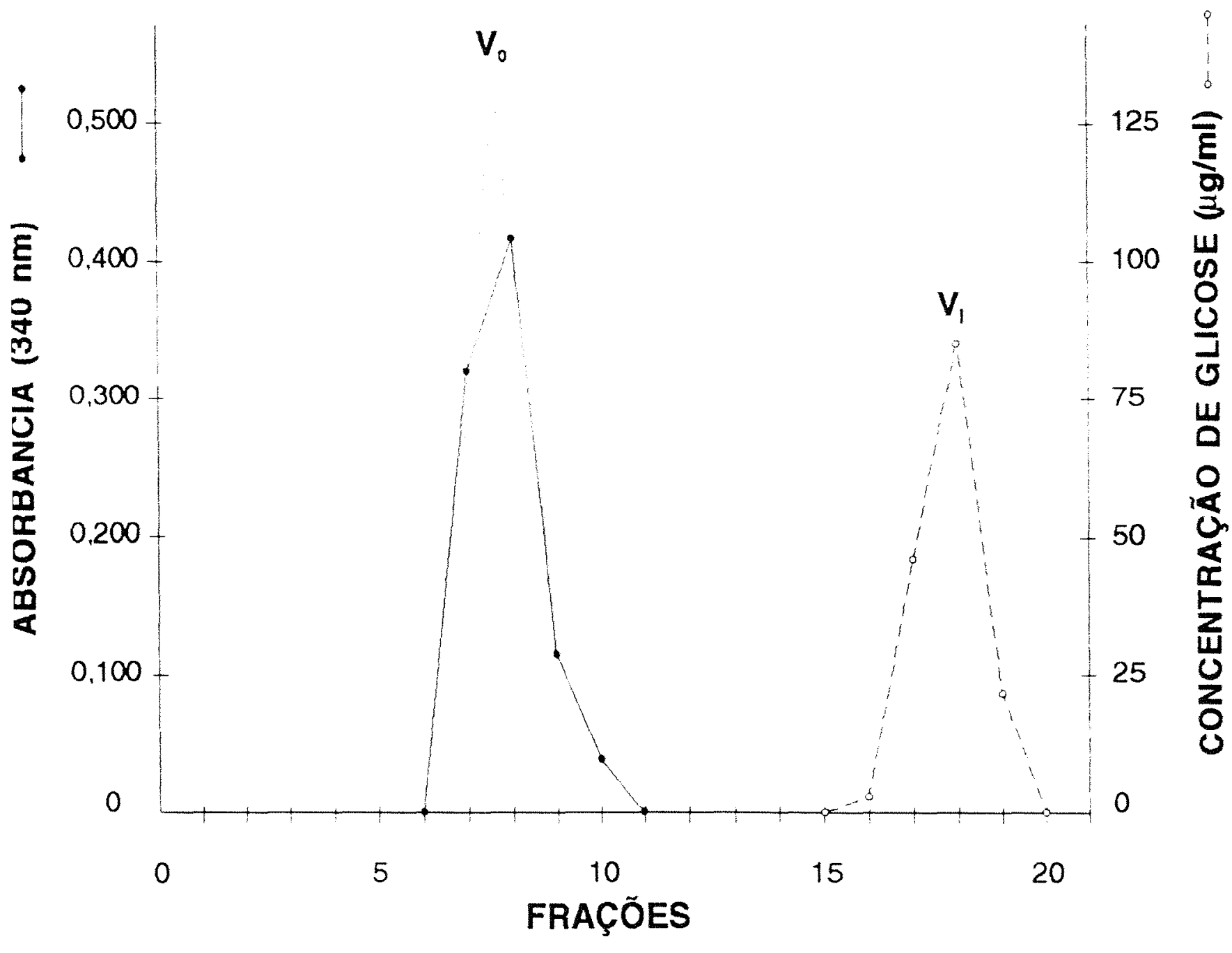

Figura 11. Determinação experimental dos volumes externo (Vo) e interno (Vi) eluídos da coluna de Sephadex G-100.

A amostra aplicada, de $2 \mathrm{ml}$, continha $4,0 \mathrm{mg}$ de Blue Dextran 2.000 e 0.5 $\mathrm{g}$ de glicose. As frações eram de $4 \mathrm{ml}$ cada. O Blue Dextran $2.000(\longmapsto)$ foi detectado pela absorbância à $340 \mathrm{~nm}$ e a glicose $(0-\infty)$ pelo teste de antrona. 


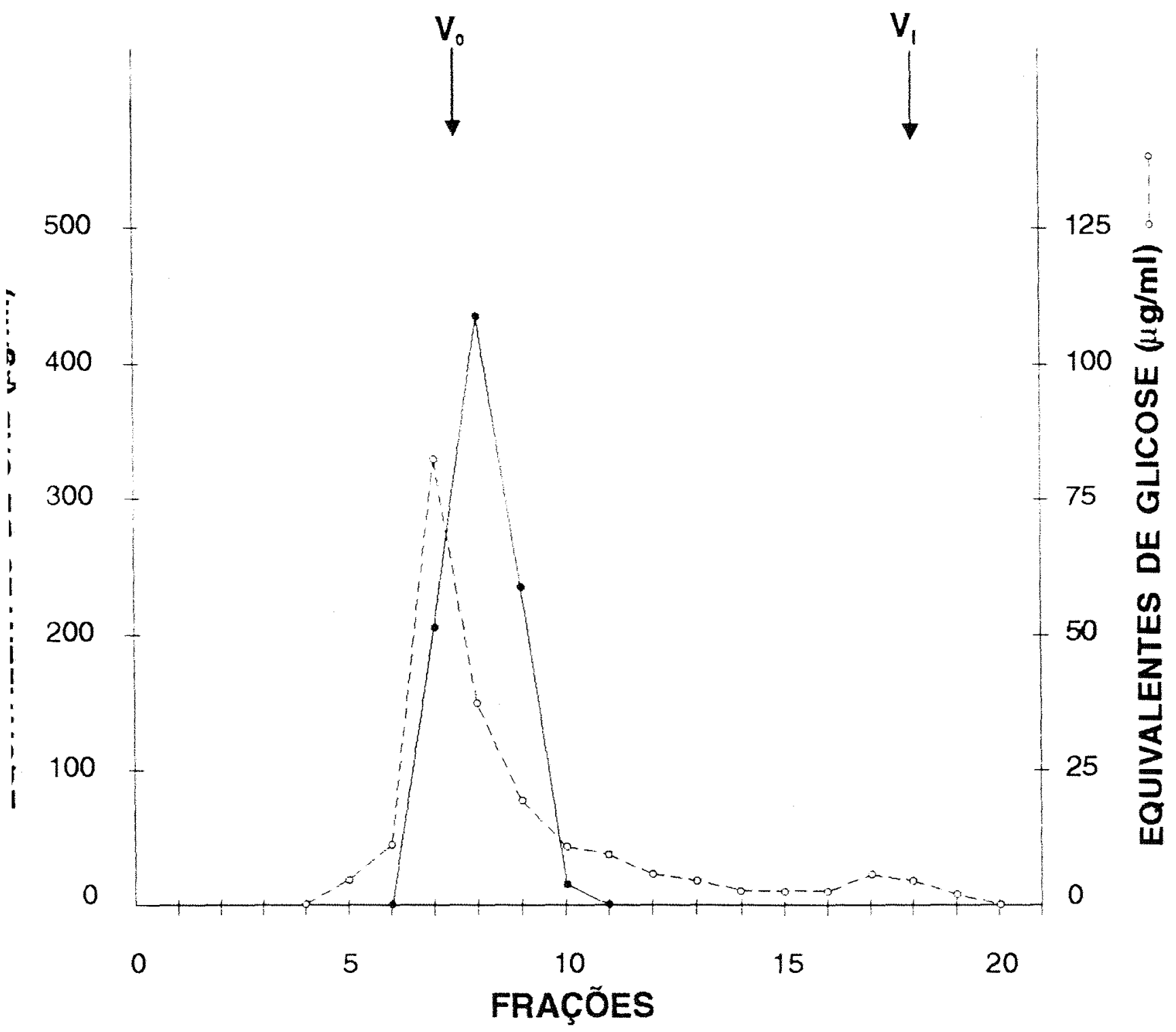

Figura 12. Filtração da fração MN-TI em coluna de gel de Sephadex G-100. As frações foram de $4 \mathrm{ml}$ cada. As concentrações de proteínas e carboidratos das frações eluídas foram medidas respectivamente por teste de Lowry e de antrona. As setas indicam os volumes externo ( Vo $=30,5$ $\mathrm{ml})$ e interno $(\mathrm{Vi}=72,0 \mathrm{ml})$, determinados experimentalmente. 


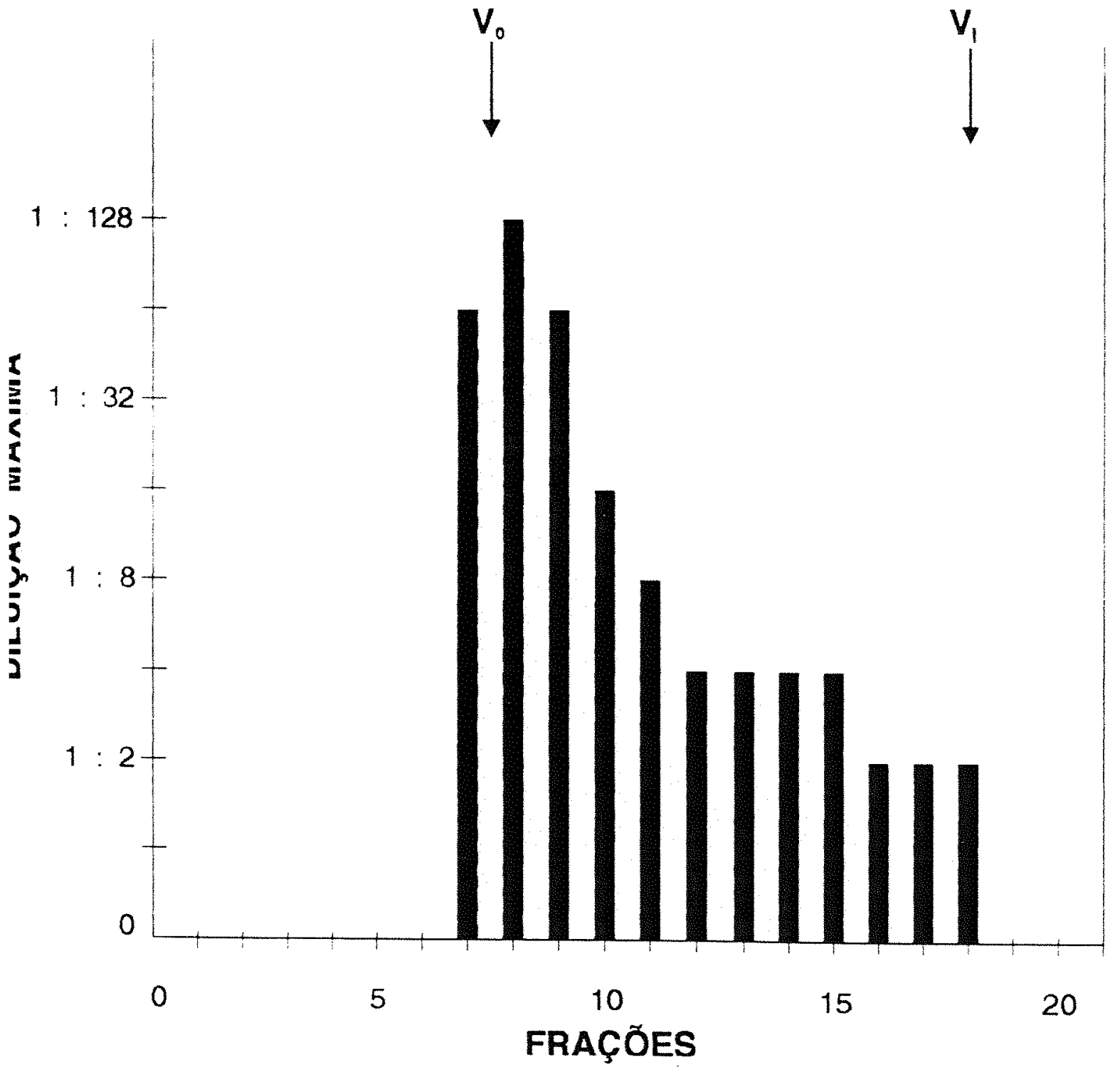

Figura 13. Quantificação dos antígenos comuns presentes nas frações eluídas da coluna de Sephadex G-100.

As barras representam a diluição máxima de cada fração, na qual ainda era visível a formação de linha de precipitação em teste de dupla difusão em ágar, utilizando-se anticorpos produzidos pela galinha $\mathrm{C}(\mathrm{Ac}-\mathrm{HvC})$. 
Tabela 3. Comparação do grau de pureza dos antigenos comuns presentes nas frações provenientes do extrato bruto de C. arabica cv. Mundo Novo.

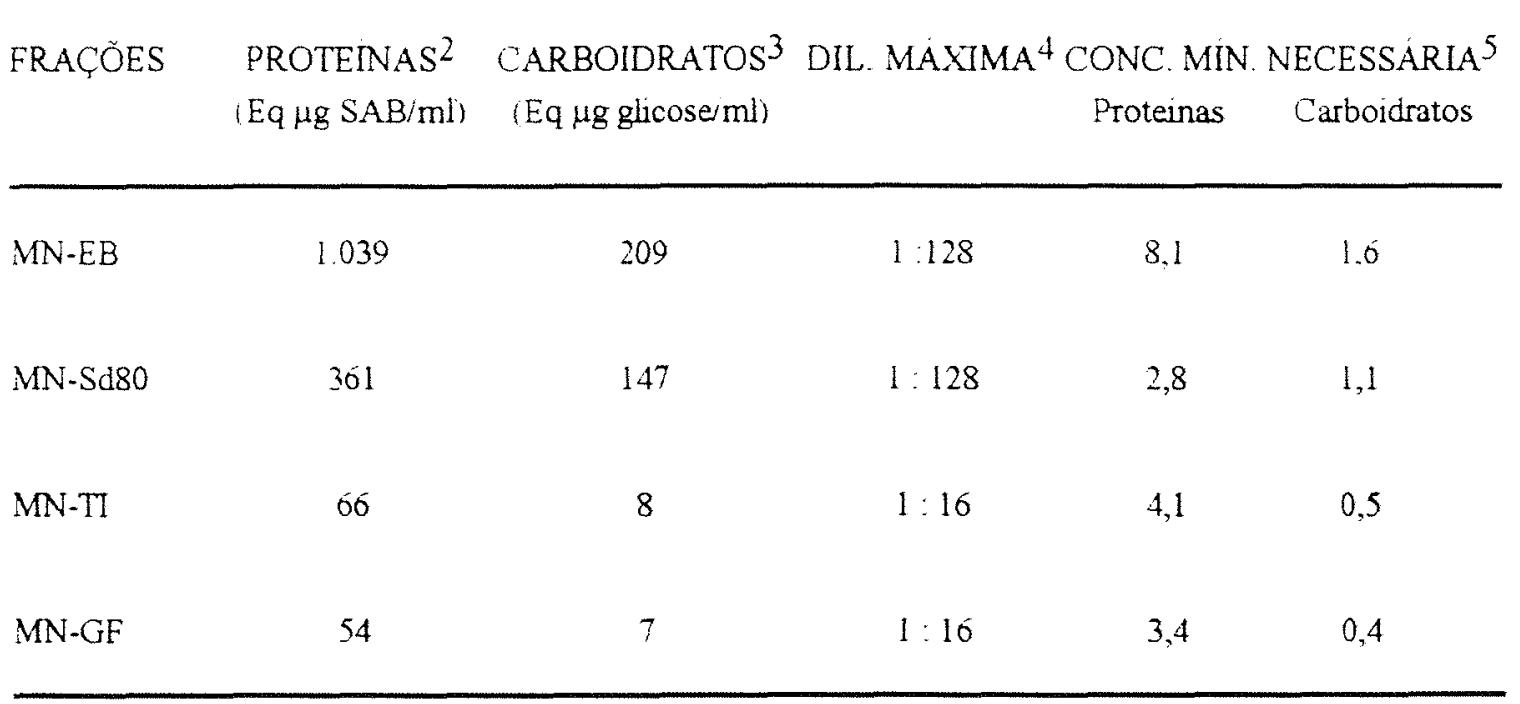

1. Os resultados apresentados, referentes às concentrações de proteínas e carboidratos, representam a média de dois experimentos com 3 réplicas cada.

2. Concentração de proteinas determinada pelo teste de Lowry.

3. Concentração de carboidratos determinada pelo teste de antrona.

4. Diluição máxima da fração, na qual ainda era visivel a formação de linha de precipitação em teste de dupla difusão em ágar.

5. Obtida pela divisão das concentrações de proteínas ou carboidratos, pelo valor da diluição máxima. 
conteúdo de proteínas ou carboidratos de cada amostra pelos respectivos valores de diluição máxima.

A análise dos valores das concentrações minimas necessárias mostra, em relação aos carboidratos, um ligeiro, porém progressivo, aumento no grau de pureza dos antigenos comuns ao longo das etapas realizadas, entretanto, em relação às proteínas, o mesmo não pôde ser constatado. Maiores considerações sobre estes dados serão feitas no item 5.3. da Discussão.

\subsection{ESTUDOS SOBRE A NATUREZA QUÍMICA DOS ANTÍGENOS CO- MUNS}

\subsubsection{TRATAMENTO COM METAPERIODATO DE SÓDIO}

As aliquotas do MN-GF, tratadas com solução de metaperiodato de sódio $15 \mathrm{mM}$, não perderam a capacidade de reagir com os anticorpos produzidos pela galinha C (Ac-HvC).

\subsubsection{TRATAMENTO COM PRONASE}

Ambas as alíquotas do MN-GF tratadas com 25 e $50 \mu \mathrm{l}$ da solução de pronase $0,02 \%$, mantiveram a reação sorológica indicadora da presença dos antigenos comuns.

\subsubsection{TRATAMENTO TERMICO}

Dos tratamentos térmicos realizados com amostra do MN-GF: banho-maria fervente por 30 e $60 \mathrm{~min}$ e autoclavagem a $120^{\circ} \mathrm{C}$ por $30 \mathrm{~min}$, somente 0 último causou perda da reação sorológica. 


\section{DISCUSSÃO}

\subsection{PRODUÇÃO DE ANTICORPOS POR GALINHAS POEDEIRAS}

Os resultados obtidos com a utilização de galinhas poedeiras para a produção de anticorpos, mostraram que esses animais representam alternativa viável ao uso de coelhos. confirmando a experiência de outros pesquisadores que fizeram uso deste tipo de ave (CARROLL \& STOLLAR, 1983; SONG et alii, 1985; BAR-JOSEPH \& MALKNNSON, 1980; VIEIRA et alii, 1984; BURDSALL et alii, 1990).

Em relação aos aspectos práticos da utilização de galinhas poedeiras destacaram-se a facilidade no trato, bastando o fornecimento diário de ração e água, a não ocorrência de doenças e a fácil manipulação para a injeção do antígeno.

A utilização da técnica de extração de anticorpos a partir das gemas dos ovos, por tornarem as sangrias desnecessárias, permitiu um acompanhamento diário da resposta imunológica da ave, sem injuriá-la, assim como a obtenção de grandes quantidades de anticorpos para os testes sorológicos. Outra facilidade resultante dessa técnica consistiu na possibilidade de se conservar os ovos em geladeira e proceder a extração de seus anticorpos de uma só vez, o que não seria possivel no caso de realização de sangrias.

A metodologia de POLSON et alii (1985) mostrou-se de fácil aplicação, sendo acessível a qualquer laboratório que disponha de centrífuga refrigerada capaz de desenvolver entre 8.000 a $12.000 \mathrm{~g}$ e, de preferencia, com rotor que comporte tubos com capacidade acima de $40 \mathrm{ml}$.

A galinha designada pela letra $\mathrm{A}$, imunizada com antigenos da raça II de $H$. vastatrix, e cuja produção de anticorpos foi acompanhada por 53 dias após a última injeção, possibilitou a obtenção de anticorpos com título de até $1: 32$. Esse valor fai obtide em oves pestos de $18^{\circ}$ ao $41^{\circ}$ dia após a última injeção. A comparação destes resultados com aqueles obtidos por outros pesquisadores, que também utilizaram galinhas poedeiras, deve ser feita levando-se em consideração as diferenças na natureza e 
concentração do antígeno imunizante, cronograma e via de injeção dos antígenos, assim como o método de extração dos anticorpos.

POLSON et alii (1980), por exemplo, obtiveram titulos máximos variando de $1: 64$ a $1: 512$, para galinhas imunizadas com diferentes tipos de virus.

Com relação ao tempo necessário para se atingir o titulo máximo, POLSON et alii (1980) e RICKE et alii (1988) obtiveram-no em 20 dias após o início da imunização e SHIMLU et alii (1990), em 35 dias. No presente trabalho foram necessários 50 dias, desde o início da imunização, explicados, possivelmente, pela baixa concentração do antígeno imunizante.

Os anticorpos produzidos pela galinha $\mathrm{A}$ apresentaram reação mais intensa com antígeno homólogo, quando utilizada a concentração de $1,4 \mathrm{M}(8,0 \% \mathrm{p} / \mathrm{v}) \mathrm{de}$ $\mathrm{NaCl}$ adicionado ao tampão do gel de ágar. Segundo CROWLE (1973), anticorpos do tipo $7 \mathrm{~S}$ de aves. apresentam agregação espontânea em concentrações salinas acima de $5,8 \% \mathrm{p} / \mathrm{v}$, formando trímeros ou tetrâmeros, o que causaria aumento de sua capacidade de precipitação.

Nem sempre, porém, concentrações mais elevadas do sal resultam em linhas de precipitação mais intensas. POLSON et alii (1980) verificaram que para antígenos virais, a utilização de concentração $0,14 \mathrm{M}(0,8 \% \mathrm{p} / \mathrm{v})$ de $\mathrm{NaCl}$ proporcionava melhores resultados, provavelmente porque em altas concentrações do sal ocorreriam mudanças irreversíveis nas estruturas terciárias antigênicas.

\subsection{COMPARAÇÕES SOROLÓGICAS ENTRE RAÇAS DE H. vastatrix}

Os anticorpos Ac-HvII e Ac-HvIII, produzidos pelas galinhas A e B respectivamente, não apresentaram especificidade ao nível de raça pois reagiram igualmente com antígenos homólogos e heterólogos. Além disso, a absorção destes anticorpos com antígenos heterólogos causou perda completa da reação com antígenos homólogos.

$A$ inespecificidade desses anticorpos não constitui surpresa visto que as diferenças existentes entre raças de um mesmo fungo são mínimas. RATAJGLRANOWSKA et alii (1984), por exemplo, utilizando imunoeletroforese cruzada em tandem, verificaram que de 52 moléculas antigênicas presentes na raça 3 de $F$. axysporum f. sp. Lupini, 51 eram comuns a raça 2 do mesmo fungo. Utilizando 
eletroforese em duas dimensões, HOWES et alii (1982) verificaram que 4 raças diferentes de Puccinia graminis Pers. f. sp. tritici Eriks. et E. Henn. apresentam mais de 270 polipeptídios, extraídos de urediniosporos, em comum. Somente 18 polipeptidios não eram comuns a essas 4 raças.

Portanto, para a distinção das raças de $H$. vastatrix seriam necessários não somente anticorpos reativos a uma parcela maior dos determinantes antigênicos presentes nos extratos do fungo, mas também a utilização de teste sorológico que permitisse a deteç̧ão de todos esses determinantes, como a imunoeletroforese cruzada em tandem ou o "western blotting".

Outra alternativa para a distinção sorológica das raças, seria a produção de anticorpos monoclonais. HARDHAM et alii (1986) obtiveram anticorpos especificos ao isolado de $P$. cinnamomi por eles estudado e WYCOFF \& AYERS (1990) conseguiram distinguir não só raças de $P$. megasperma f. sp. glycinea. como também diferentes isolados da mesma raça.

O emprego de técnicas sorológicas para a detecção de diferenças entre raças de um patógeno, constitui uma das estratégias para se determinar quais moléculas atuam no mecanismo de reconhecimento raça-específico pois, dentre as moléculas que diferem de uma raça para outra, devem estar aquelas que decorrem da presença de diferentes genes de avirulência. Os resultados obtidos no presente trabalho mostram que as moléculas imunodominantes, isto é, que desencadeiam maior produção de anticorpos, são comuns às raças II e III de $H$. vastatrix, portanto, para se obter anticorpos que evidenciem diferenças entre estas, seriam necessárias imunizações mais intensas dos animais, para que estes produzam anticorpos, também contra as moléculas de menor capacidade imunogênica ou que estão presentes em pequenas concentrações nos antígenos imunizantes.

Conforme já discutido anteriormente, a utilização de anticorpos monoclonais poderia evidenciar diferenças entre as raças de $H$. vastatrix e permitiria, possivelmente, a associação destas diferenças aos genes de avirulência. Entretanto, a obtenção destes anticorpos é dificultada pelas exigências da metodologia quanto aos recursos do laboratório.

Uma maneira mais acessivel, e elegante. para se obter anticorpos para os antigenos presentes em baixas concentrações ou de menor capacidade imunogênica, seria a utilização do processo de imunização em "cascata" proposto por THALHAMER \& FREUND (1984). Esta técnica baseia-se na remoção dos 
componentes antigênicos imunodominantes, presentes no antígeno imunizante, por absorção em coluna de imunoafinidade preparada com os anticorpos produzidos por um animal que já recebeu uma primeira injeção do antígeno bruto. Dessa maneira, os antigenos aos quais o animal responde mais rapidamente são retidos na coluna, enquanto que os antígenos para os quais o animal ainda não respondeu, passam livremente e podem ser utilizados na injeção seguinte. Utilizando esta técnica. ANICETTI et alii (1989) verificaram, em comparação com a imunização convencional, um aumento na produção de anticorpos contra antígenos secundários de uma mistura de proteínas extraídas de Escherichia coli (Migula) Castellani et Chalmers.

Através da imunização em "cascata" seria possível aumentar a resposta imunológica dos animais, contra antígenos de menor imunogenicidade presentes nos extratos de raças de $H$. vastatrix, aumentando. consequentemente. a possibilidade de se obter anticorpos para os antígenos raça-especificos e. dentre estes, aqueles decorrentes da expressão dos genes de avirulência.

Outro procedimento que poderia aumentar as chances de se detectar as moléculas relacionadas aos genes de avirulência, consistiria em induzir a formação das estruturas de infecção de $H$. vastatrix (tubo de germinação, apressório, vesícula subestomática, célula mãe de haustório e haustório) e então proceder a extração dos antígenos, pois é possivel que os genes de avirulência só se expressem durante o processo de infecção da planta pelo fungo.

\subsection{ANTÍGENOS COMUNS: DETECÇÃO, PURIFICAÇÃo E NATUREZA QUT́MICA}

A presença de antígenos comuns a Coffea spp. e $H$. vastatrix foi detectada através da reação dos anticorpos $\mathrm{Ac}-\mathrm{HvC}$ (para antígenos do fungo coletado no campo) com antígenos extraídos de cafeeiros de diversas espécies. Na reação recíproca. os anticorpos Ac-MN (para antígenos de cafeeiro Mundo Novo) não detectaram antigenos comuns em extrato do fungo. Esses resultados reproduzem parcialmente aqueles obtidos por ALBA et alii (1983), pois estes detectaram tais antígenos tanto com o anti-soro para o fungo como com $\circ$ anti-soro para o cafeeiro.

A não detecção de antígenos comuns através dos anticorpos Ac$M N$, pode ser atribuída ao fato de as doses de reforço aplicadas na galinha $D$ terem 
consistido de antígeno emulsionado em adjuvante incompleto de Freund, o qual é menos eficiente na estimulação do sistema imunológico. Optou-se por esse tipo de adjuvante devido a galinha $\mathrm{C}$, que recebeu todas as aplicações com o adjuvante completo, ter apresentado ulcerações nos locais injetados.

Os antigenos comuns foram detectados em todas as espécies de cafeeiros estudadas, quais sejam: C. arabica, C. liberica, C. eugenioides, $C$. congensis, C. canephora cultivares Robusta e Kouillou e o híbrido Sarchimor. Considerando que o híbrido Sarchimor pertence ao grupo fisiológico $A$, o qual engloba plantas resistentes a todas as raças conhecidas de $H$. vastatrix, conclui-se que a simples presença dos antígenos comuns não determina a suscetibilidade do hospedeiro.

A deteç̧ão de antígenos comuns a planta e patógeno, mesmo em combinações incompativeis de cultivares e raças, foi também relatada por CHARUDATTAN \& DEVAY (1972), PALMERLEY \& CALLOW (1978), ALBA et alii (1983), ALBA \& DEVAY (1985), HEIDE \& SMEDEGAARD-PETERSEN (1985), ABD-EL-REHIM et alii (1988a e b) e SCALA \& CRISTINZIO (1988).

Considerando que, na interação entre o algodão e fungos dos gêneros Fusarium e Verticillium, a resistência do hospedeiro só é expressada após a infecção das raízes e invasão do sistema vascular, CHARUDATTAN \& DEVAY (1972) sugeriram que os antigenos comuns, presentes tanto nas combinações compativeis como nas incompatíveis destes organismos, estariam relacionados ao processo de infecção e estabelecimento do patógeno mas não determinariam o desenvolvimento da doença.

Os estudos histológicos da interação entre $H$. vastatrix e cafeeiros, realizados por MARTINS (1988), mostraram que, no híbrido Sarchimor, os primeiros sinais de incompatibilidade ocorrem $48 \mathrm{~h}$ após a inoculação, quando o fungo forma a $1^{\mathrm{a}}$ célula mãe de haustório. Segundo a autora, o reconhecimento do patógeno pelo hospedeiro deve se dar logo após a formação da vesícula sub-estomática ou da hifa de infecção que se desenvolve em seguida. Portanto, ao contrário do que ocorre no algodoeiro, a expressão da resistência no cafeeiro ocorre rapidamente após a infecção pelo fungo.

Apesar destas diferenças existentes entre o algodoeiro e o cafeeiro. quanto a expressão da resistência, os dados do presente trabalho não invalidam a hipótese de CHARLDATTAN \& DEVAY (1972) segundo a qual os antígenos comuns estariam relacionados à compatibilidade básica entre o patógeno e o hospedeiro. A ocorrência de tais antígenos em todas as espécies de cafeeiros estudadas, suscetíveis e resistentes, sugere 
uma relação destas moléculas com a compatibilidade básica do fungo $H$. vastatrix com plantas do gênero Coffea.

Os antígenos comuns presentes no extrato bruto de folhas de cafeeiro Mundo Novo (MN-EB), foram totalmente precipitados pela adição de etanol à concentração final de $80 \% \mathrm{~V} / \mathrm{v}$, resultando numa purificação parcial destas substâncias. Este resultado está de acordo com o obtido por ALBA et alii (1983) que, após precipitação etanólica fracionada do extrato foliar de cafeeiro suscetivel, detectaram estes antígenos nas frações obtidas com $60 \%$ e $80 \%$ de concentração do solvente.

Apesar da utilização de agitador de ultra-som, não foi possível ressolubilizar parte do precipitado obtido pela adição do etanol, o qual permaneceu na forma de flocos e foram removidos por filtração em membrana. A baixa taxa de recuperação de proteinas $(55,82 \%$ - Tabela 2$)$ deve-se, provavelmente. a este fenômeno.

Previamente à precipitação etanólica, o extrato foliar foi concentrado através de ultrafiltração em membrana Amicon YM 10, a qual é permeável a moléculas menores que 10.000 daltons. Como não foram detectados antígenos comuns no ultrafiltrado, conclui-se que estas substâncias apresentam dimensão maior que 10.000 daltons.

A cromatografia de troca iônica, em coluna de DEAE Sephadex A25 , revelou uma heterogeneidade dos antígenos comuns quanto a afinidade pelo trocador aniônico, pois foram eluídos pelo gradiente de $\mathrm{NaCl}$, em concentrações variando, aproximadamente, de 0,3 a $0,8 \mathrm{M}$. Houve uma separação substancial dos carboidratos em relação às proteinas pois os primeiros apresentaram menor afinidade pelo trocador que as últimas. As eluições das proteinas e dos antígenos comuns mostraram-se coincidentes na maior parte das frações obtidas com o gradiente de $\mathrm{NaCl}$. $\mathrm{O}$ fato de as proteínas não terem sido detectadas em frações que continham antígenos comuns, poderia ser explicada pela maior sensibilidade do teste de dupla difusão em relação ao teste de Lowry. Segundo MATHEWS (1967), até 0,1 $\mathrm{g}$ de TYMV ("turnip yellow mosaic virus" = virus do mosaico amarelo do nabo) pode ser detectado através de teste de dupla difusão em lâmina de microscopia, enquanto que, pela experiência pessoal, o teste de Lowry apresenta perda de precisão em concentrações proteicas menores que $10 \mu \mathrm{g} / \mathrm{ml}$.

Através da filtração em gel de Sephadex G-100, foi verificado que os antigenos comuns são heterogêneos. também, quanto à dimensão de suas moléculas, pois foram eluídos em várias frações compreendidas entre os volumes externo e interno da coluna. Maiores concentrações destes antígenos foram detectadas nas frações 
próximas ao volume externo, indicando pesos moleculares iguais ou maiores que 150.000 daltons (baseando-se no valor do limite de exclusão para proteínas globulares indicada pelo fabricante do gel).

Na filtração em gel foi observada, também, na maior parte das frações, uma correlação entre a eluição das proteínas e dos antigenos comuns. A ocorrència de algumas frações contendo antigenos comuns, mas não proteínas. poderia ser explicada, novamente, pela menor sensibilidade do teste de Lowry.

Os dados da tabela 3 não indicam uma diminuição gradativa da concentração mínima necessária para a deteç̧ão dos antígenos comuns, como seria esperado caso houvesse ocorrido uma purificação destas substâncias. Essa diminuição foi verificada somente para a precipitação etanólica. principalmente em relação às proteinas: e para a cromatografia de troca iônica, em relação aos carboidratos.

Esse insucesso na purificação pode ser atribuido à heterogeneidade apresentada pelos antígenos comuns, tanto na cromatografia de troca iônica como na filtração em gel. Apesar de, nestes dois processos, terem sido detectados picos na eluição dos antígenos comuns, optou-se pelo agrupamento de todas as frações positivas para a sua presença, pois julgou-se ser a heterogeneidade uma característica importante destas substâncias.

$\mathrm{Na}$ análise dos dados referentes à purificação dos antigenos comuns deve ser levada em consideração a existência de uma margem de erro nos valores das concentrações minimas necessárias, decorrente da imprecisão do teste de determinação da diluição máxima o qual foi baseado na avaliação visual da formação, ou não, de linha de precipitação. $\dot{A}$ esta imprecisão podemos atribuir o fato das frações $M N-T I$ e MN-GF terem apresentado menor grau de pureza, quanto às proteínas, que a fração $\mathrm{MN}-\mathrm{Sd} 80$, a qual, teoricamente, deveria ser menos pura.

Evidências da heterogeneidade dos antígenos comuns ao cafeeiro e H. vastatrix já haviam sido obtidas anteriormente por ALBA et alii (1983). Esses autores verificaram que os antígenos comuns extraídos tanto do fungo quanto da planta, quando submetidos à precipitação fracionada com etanol ou sulfato de amônio. perdiam solubilidade em vários niveis de concentração ou saturação do agente precipitante. ALBA \& DEVAY (1985) verificaram comportamento semelhante dos antígenos comuns a $P$. infertans e batata.

A heterogeneidade foi também evidenciada para os antigenos comuns das interações $F$. oxysporum f. sp. vasinfectum $\mathrm{x}$ algodão, pela formação de 
várias linhas de precipitação em teste de dupla difusão em ágar (ABD-EL-REHM et alii, 1988b); M. phaseolina x soja, pela formação de vários arcos de precipitação em imunoeletroforese (CHAKRABORTY \& PURKAYASTHA, 1983) e P. fragariae $\mathrm{x}$ morango, pela formação de várias bandas em "western blotting" (MOHAN, 1989).

Os dados do presente trabalho, assim como os daqueles acima descritos. indicam que a heterogeneidade dos antígenos comuns é um fenômeno difundido nas interações patógeno-planta. Essa heterogeneidade pode ser interpretada de duas maneiras (não excludentes): os antígenos compreendem vários tipos diferentes de moléculas, cada qual capaz de induzir a formação de um anticorpo específico, ou esses antígenos compreendem moléculas diversas que apresentam um epitopo em comum. o qual induz a formação de somente um tipo de anticorpo. Qualquer que seja o caso. entretanto. a ubiquidade dos antígenos comuns sugere que ao longo do processo evolutivo, o meio interno das plantas causou seleção das formas de patógenos portadoras destas substâncias.

Os dados da cromatografia de troca iônica e da filtração em gel indicam que os antígenos comuns têm composição essencialmente proteica, porém, a não suscetibilidade destes ao tratamento com pronase, assim como a resistência ao tratamento térmico em banho-maria fervente por $60 \mathrm{~min}$, sugerem que o epitopo ao qual os anticorpos se ligam é de natureza polissacaridica. É possivel, portanto, que os antígenos comuns a $H$. vastatrix e Coffea spp. sejam glicoproteínas. A resistência ao tratamento com metaperiodato de sódio não invalida esta hipótese pois o epitopo polissacaridico em questão pode ser constituido por monossacarídios não suscetíveis à oxidação por este agente, ou seja, unidades que não possuam em sua cadeia carbonos adjacentes apresentando grupos hidroxila.

Natureza glicoproteica foi encontrada também para os antígenos comuns a $F$. axysporum f. sp. vasinfectum e algodão, por CHARUDATTAN \& DEVAY (1981). Estes antigenos apresentaram resistência aos tratamentos térmico e com enzimas proteolíticas, tendo predominância polissacaridica em sua composição ( $75 \%$ carboidrato, $16 \%$ fósforo e $9 \%$ proteína).

A utilizaçào do complexo $H$. vastatrix x Coffea spp., para o estudo da interação patógeno-hospedeiro, apresenta algumas características que dificultam a realização dos experimentos, como, por exemplo:

- o fungo é um parasita obrigado para o qual ainda não foi possivel o cultivo em meio artificial, o que limita a disponibilidade de material para os estudos, além de dificultar a 
obtenção de material livre de contaminação por outros microorganismos,

- o hospedeiro é uma planta de desenvolvimento lento. se comparado com plantas de culturas anuais, o que exige o seu plantio com meses de antecedência à data de seu uso.

Face a esses contratempos, estudos mais aprofundados sobre a interação patógeno-hospedeiro, especialmente sobre os antígenos comuns. seriam facilitados se empregado outro sistema, no qual o patógeno pudesse ser cultivado em meio sintético e o hospedeiro apresentasse desenvolvimento mais acelerado (de preferência uma planta de cultura anual). Esse sistema deveria apresentar também uma característica favorável da interação $H$. vastatrix $\mathrm{x}$ Coffea spp. que consiste na disponibilidade de várias raças do patógeno assim como de vários cultivares do hospedeiro, portadores de diferentes combinações dos genes de resistência.

Os recentes avanços no campo da manipulação genética de plantas. permitirão num futuro próximo o desenvolvimento de inúmeras variedades resistentes a doenças, porém. isto dependerá de um profundo conhecimento dos fenômenos que desencadeiam, ou inibem, a expressão da resistência por parte do hospedeiro. Dentro deste contexto, a ocorrência generalizada de antígenos comuns a patógenos e plantas é um dos fenômenos que necessitam de maior compreensão e, para tal, técnicas sorológicas e bioquímicas mais refinadas têm muito a contribuir. 


\section{CONCLUSÕES}

- A utilização de galinhas poedeiras constitui uma alternativa viável para a produção de anticorpos a serem utilizados em testes sorológicos, uma vez que esses animais apresentam facilidade no trato diário e na manipulação para a injeção dos antigenos. aliados a uma boa resposta imunológica mesmo com baixas concentrações do antigeno imunizante.

- A metodologia de POLSON et alii (1985) para a extração dos anticorpos presentes nas gemas dos ovos, além de tornarem desnecessárias as sangrias, é de fácil aplicação e requer reagentes de baixo custo e em pequenas quantidades, sendo acessivel a qualquer laboratório que disponha de centrífuga refrigerada capaz de desenvolver acima de $8.000 \mathrm{~g}$ e, de preferência com rotor que comporte tubos com capacidade acima de $40 \mathrm{ml}$.

- Os antigenos imunodominantes presentes nos extratos de urediniosporos são comuns às raças II e III de $H$. vastatrix. Portanto, para que diferenças antigênicas entre raças possam ser detectadas, são necessárias modificações na metodologia de imunização assim como o emprego de testes sorológicos com maior poder de resolução.

- Para os antígenos de $H$. vastatrix e de cafeeiros, as linhas de precipitação formadas em gel de ágar preparado com tampão adicionado de $\mathrm{NaCl}$ à concentração de $1,4 \mathrm{M}$ foram mais intensas do que aquelas formadas em presença do sal à concentração de $0,14 \mathrm{M}$.

- Antigenos comuns a $H$. vastatrix e cafeeiros pertencentes a diversas espécies do gênero Coffea foram detectados através de anticorpos produzidos para antigenos do fungo, porém essa deteç̧ão não foi possivel através de anticorpos produzidos para antigenos de cafeeiro.

- Os antígenos comuns presentes no extrato foliar de cafeeiro são precipitados com 
etanol à concentração final de $80 \% \mathrm{v} / \mathrm{v}$, apresentam afinidade pelo trocador aniônico DEAE Sephadex A-25 e são eluídos principalmente no volume externo de coluna de gel de Sephadex G-100.

- Esses antigenos mostram comportamento heterogêneo tanto na cromatografia de troca iônica quanto na filtração em geh, apresentando pesos moleculares variados, mas predominantemente maiores ou iguais a 150.000 daltons.

- Os antígenos comuns presentes nos extratos de folhas de cafeeiro são resistentes à fervura em banho-maria por até $60 \mathrm{~min}$, porém a autoclavagem a $120^{\circ} \mathrm{C}$ por $30 \mathrm{~min}$ causa perda completa da reação sorologica. Tratamentos com pronase e metaperiodato de sódio não afetaram a reação sorológica destes antígenos. 


\section{REFERÊNCIAS BIBLIOGRÁFICAS}

ABD-EL-REHIM. M. A.; ABOU-TALEB, E. M.; TOHAMY, A. Common antigen(s) in cotton to Fusarium oxysporum f. sp. vasinfectum. J. Phvtopathology, Berlin. 121: 217-23, 1988a

ABD-EL-REHIM. M. A.: ABOU-TALEB. E. M.; TOHAMY. A. Lectins specificity to pathogenesis of Fusarium axysporum f. sp. vasinfectum. J. Phytopathology, Berlin. 121:1-7, 1988b.

ABD-EL-REHIM, M. A.; IBRAHIM, I. A.; MICHAIl, S. H.; FADEL, F. M. Serological and immunoelectrophoretical studies on resistant and susceptible watermelon varieties to Fusarium semitectum Berk. and Rav. Phytopath. Z., Berlin, $71: 49-55,1971$

ALBA, A. P. C. \& DEVAY, J. E. Detection of cross-reactive antigens betweenPhytophthora infestans (Mont.) de Bary and Solanum species by indirect enzyme linked immunosorbent assay. Phytopath. Z., Berlin. 112:97-104, 1985.

ALBA, A. P. C.; GUZZO, S. D.; MAHLOW, M. F. P.; MORAES, W. B. C. Common antigens in extracts of Hemileia vastatrix urediniospores and of Coffea arabica leaves and roots. Fitopatologia Brasileira, Brasilia, 8:473-483, 1983.

ALBA, A. P. C.: NAMEKATA. T.: MORAES, W. B. C.; OlIVEIRA, A. R.; FIGUEIREDO, M. B. Serological studies on coffee rust. Arq. Inst. Biol., São Paulo. 40:227-31, 1973. 
ANICETTI, V. R.; SIMONETTI, M. A.; BLACKWOOD, L. L.; JONES. A. J. S.; CHEN, A. B. Immunization procedures for E. coli proteins. Appl. Biochem. Biotechnol., Clifton, 22:151-68, 1989.

BADE, H. \& STEGEMANN, H. Rapid method of extraction of antibodies from hen egg yolk. J. Immunol. Methods, Amsterdam. 72:421-6, 1984.

BAJUNGU, H. E. Caracterização patogênica, serológica e fisiológica de Colletotrichum gloeosporioides Penz. (sensu Arx, 1957) f. sp. cepae n. c. Piracicaba, 1979. 35p. (Mestrado - Escola Superior de Agricultura "Luiz de Queiroz"/USP).

BAR-JOSEPH. M. \& MALKINSON, M. Hen egg yolk as a source of antiviral antibodies in the enzyme-linked immunosorbent assay (ELISA): a comparison of two plant viruses. Virological Methods. Amsterdam, 1:179-83, 1980.

BHATTACHARYYA, B. \& PURKAYASTHA, R. P. Occurrence of common antigens in jute and Colletotrichum corchori. Current Science, Bangalore, 54:251-2, 1985.

BERETTA, M. J. G.; MARTINS, E. M. F.; MORAES, W. B. C. Induced protection to Hemileia vastatrix at a distance from the site of the inducing action in coffee plants. Summa Phytopathologica, Piracicaba, 3:66-70, 1977.

BERKELEY, M. J. The gardeners' chronicle. The gardeners'chronicle and agricultural gazette. London. 6 de nov. 1869.

BREWIN, N. J.; WOOD, E. A.; BRADLEY, D. J.; BUTCHER, G. W. Surface interactions between Rhizobium and infected pea root nodule cells, as revealed by using monoclonal antibodies. In: BAILEY, J. A., ed. Biology and molecular biology of plant-pathogen interaction. Berlin, Springer-Verlag, 1986. p.99-106.

BURDSALL Jr., H. H.; BANIK, M.; COOK, M. E. Serological differentiation of three species of Armillaria and Lentinula edodes by enzyme linked immunosorbent assay using immunized chickens as a source of antibodies. Mycologia, New York, 82:41523, 1990. 
CARDOSO, R. M. L.; ZAMBOLM. L.; CHAVES, G. M. Ocorrência no Brasil da raça XVI de Hemileia vastatrix coletada do germoplasma de Coffea arabica no Estado de Minas Gerais. Fitopatol. Bras., Brasilia, 13:343-6, 1986.

CARROL, S. B. \& STOLLAR, B. D. Antibodies to calf thymus RNA polymerase II from egg yolks of immunized hens. J. Biol. Chem., Bethesda. 258:24-6, 1983.

CENTURION, M. A. P. C. Compatibilidade sexual e caracterização serológica e patogênica de Fusarium moniliforme Sheldon. Piracicaba, 1985. 69p. Mestrado Escola Superior de Agricultura "Luiz de Queiroz" (USP).

CHAKRABORTY, B. N. \& PURKAYASTHA. R. P. Serological relationship between Macrophomina phaseolina and soybean cultivars. Phvsiol. Plant Pathol., London. 23:197-205, 1983.

CHARUDATTAN, R. \& DEVAY, J. E. Common antigens among varieties of Gossypium hirsutum and isolates of Fusarium and Verticillium species. Phytopathology, St. Paul, 62:230-4, 1972.

CHARUDATTAN, R. \& DEVAY, J. E. Purification and partial characterization of an antigen from Fusarium axysporum f. sp. vasinfectum that cross reacts with antiserum to cotton (Gossypium hirsutum) root antigens. Physiol. Plant Pathol., London, 18:289-95, 1981.

CHARUDATTAN, R. \& HUBBELL, D. H. The presence and possible significance of cross-reactive antigens in Rhizobium-legume associations. Antonie Van Leeuwenhoeck J. Microbiol. Serol., Amsterdam, 39:619-27, 1973.

CROWLE, A. J. Immunodifusion. 2. ed. New York, Academic Press, 1973. 545p.

DAZZO, F. B. \& HUBBELL, D. H. Cross-reactive antigens and lectin as determinants of symbiotic specificity in the Rhizobium-clover association. Applied Microbiol., Washington, 30:1017-33, 1975. 
DEVAY, J. E. \& ADLER, H. E. Antigens common to hosts and parasites. Ann. Rev. Microbiol., Palo Alto. 30:147-68, 1976.

DEVAY, J. E.; ROMANI, R. J.; MONADJEM, A. M.; ETZLER, M. Induction of phytoprecipitins in sunflower gall tissue in response to infection by Agrobacterium tumefaciens. Phytopathology, St. Paul, 60:1289, 1970. (Resumo).

DEVAY, J. E.; SCHNATHORST, W. C.; FODA, M. S. Common antigens and hostparasite interactions. In: MIROCHA, C. J. \& URTTANI, I. eds. The dinamyc role of molecular constituents in plant-parasite interactions. New York. Plenum Press. 1967. p.313-28.

DEVAY. J. E.: WAKEMAN, R. J.: KAVANAGH, J. A.: CHARUDATTAN, R. The tissue and cellular location of a major cross-reactive antigen shared by cotton and soil-borne fungal parasites. Phusiol. Plant Pathol, London, 18:59-66, 1981.

DISCHE, Z. General color reactions. In: WHISTLER, R. L. \& WOLFROM, M. L., eds. Wethods in carbohydrate chemistry. New York. Academic Press, 1962. vol 1, p.478-512.

DOUBLY, J. A.; FLOR, H. H.; CLAGETT, C. C. Relation of antigens of Melampsora lini and Linum usitatissimum to resistance and susceptibility. Science, Washington, 131:229, 1960.

ESKES, A. B. Incomplete resistance to coffee leaf rust (Hemileia vastatrix). Wagenigen, 1983. 140p. (Doutoramento - Landbouwhogeschool te Wageningen).

ESTRADA-GARCIA, M. T.; GREEN, J. R.; BOOTH, J. M.; WHTTE. J. G.; CALLOW, J. A. Monoclonal antibodies to cell surface components of zoospores and cysts of the fungus Pythium aphanidermatum reveal species-specific antigens. Exper. Mycology, Duluth. 13:348-55, 1989. 
FIGUEIREDO, M. B. Estudos fisiológicos e sorológicos sobre o fungo Ascochvta phaseolorum Sacc. e sobre a doença por ele causada em berinjela (Solanum melongena L.) e em outras plantas cultivadas. Piracicaba, 1972. 130p. (Doutoramento - Escola Superior de Agricultura "Luiz de Queiroz"/USP).

FIGUEIREDO, M. B.; ALBA, A. P. C.; OLIVEIRA, A. R. Sorologia aplicada ao estudo dos fungos fitopatogênicos. Summa Phytopathologica, Piracicaba 3:233-59, 1977.

FIGUEIREDO. M. B. \& NAMEKATA. T. -iscochuta phaseolorum Sacc. e outros fungos do gènero 4 scochvta. I - Sorologia e sua aplicação na sistemática. Arq. Inst. Biol.. São Paulo. 41:67-93, 1974.

GERALDI, M. A. P. Caracterização patogènica e sorológica de Colletotrichum graminicola (Ces.) Wils. (sensu Arx, 1957) do trigo e resistência varietal em Triticum aestivum L. Piracicaba, 1981. 39p. (Mestrado - Escola Superior de Agricultura "Luiz de Queiroz"/(USP).

GHINI, R. Caracterização morfologica, serológica e patogênica de espécies de Botrytis que ocorrem na cultura de cebola (Allium cepa L.). Piracicaba, $1984.53 p$. (Mestrado - Escola Superior de Agricultura "Luiz de Queiroz"/USP).

HADGE, D. \& AMBROSIUS, H. Evolution of low molecular weight immunoglobulins - IV. IgY like immunoglobulins of birds, reptiles and amphibians, precursors of mammalian IgA. Molecular Immunology, Elmsford, 21:699-707, 1984.

HALL, J. L.; FLOWERS, T. J.; ROBERTS, R. M. Plant cell structure and metabolism. London, Longman Inc., 1978. 426p.

HARDHAM. A. R.: SUZAKI, E.; PERKIN, J. L. Monoclonal antibodies to isolatespecies-, and genus-specific components on the surface of zoospores and cysts of the fungus Phytophthora cinnamomi. Can. J. Bot., Ottawa, 64:311-21, 1986. 
HASSL, A. \& ASPOCK, H. Purification of egg yolk immunoglobulins - a two step procedure using hydrophobic interaction chromatography and gel filtration. $J$. Immunol. Methods, Amsterdam, 110:225-8, 1988.

HEIDE, M. \& SMEDEGAARD-PETERSEN, V. Common antigens between barley and barley powdery mildew and their relation to resistance and susceptibility. Can. $J$. Plant Pathol., Ontario, 7:341-6, 1985.

HORNOK, L. Serotaxonomy of Fusarium species of the sections Gibbosum and Discolor. Trans. Br. Mycol. Soc.. London. 74:73-8. 1980.

HOWES, N. K.: KIM. W. K.: ROHRINGER. R. Detergent soluble polypeptides extracted from uredospores of four physiologic races of Puccinia graminis $\mathrm{f}$. $\mathrm{sp}$. tritici. Phusiol. Plant Pathol., London, 21:361-6, 1982.

HUXIEY, J. Heredity, east and west. New York, Henry Schuman Inc., 1949. 246p.

IGARASHI, S. Sensibilidade a fungicidas e caracterização morfológica, patogênica e serológica de Colletotrichum spp. do morango (Fragaria spp.). Piracicaba, 1984. 57p. (Mestrado - Escola Superior de Agricultura "Luiz de Queiroz"/USP).

INSTTTUTO BRASILEIRO DO CAFÉ. Cultura do café no Brasit: manual de recomendações. 5.ed. Rio de Janeiro, IBC-GERCA, 1985. 580p.

JENSENTUS, J. C.; ANDERSEN, I.; HAU, J.; CRONE, M.; KOCH, C. Eggs: conveniently packaged antibodies, methods for purification of yolk IgG. J. Immunol. Methods, Amsterdam, 46:63-8, 1981.

KALYANASUNDARAM, R. \& CHARUDATTAN, R. Serological studies in the genus Fusarium a comparison of strains. Phytopathol. Z., Berlin, 64:28-31, 1969.

KMATI, H. Taxonomia, esporulação e patogenicidade de Colletotrichum graminicola (Ces.) Wils. (sensu Arx, 1957). Piracicaba, 1975. 103p. (Livre Docência - Escola Superior de Agricultura "Luiz de Queiroz"(USP). 
KOGEL, G.; BEISSMANN, B.; RESSENER, H. J.; KOGEL, K. H. A single glycoprotein from Puccinia graminis f. sp. tritici cell walls elicits the hypersensitive lignification response in wheat. Physiol. Mol. Plant Pathol., London. 33:173-85, 1988.

KUSHALAPPA. A. C. \& ESKES, A. B. Advances in coffee rust research. Ann. Rev. Phytopathol., Palo Alto, 27:503-31, 1989.

LAINE, A. C. \& FAYE, L. Significant immunological cross-reactivity of plant glycoproteins. Electrophoresis, Deerfield Beach. 9:841-4. 1988.

LESLIE. G. A. \& CLEM. L. W. Phylogeny of immunoglobulin structure and function III. Immunoglobulins of the chicken. J. Exp. Med., New York. 130:1337-52. 1969.

LOWRY, O. H.; ROSEBROUGH, N. J.; FARR, A. L.; RANDALL, R. J. Protein measurement with the folin phenol reagent. J. Biol. Chem.,Baltimore, 193:265-75, 1951 .

MADHOSINGH, C. A serological comparison of three Fusarium species. Can. J. Bot., Ottawa. 42:1143-6, 1964.

MARTINS, E. M. F. Seqüência de eventos primários do desenvolvimento de Hemileia vastatrix em folhas de cafeeiro com suscetibilidade genética, resistência induzida ou resistência genética. Piracicaba, 1988. 149p. (Mestrado - Escola Superior de Agricultura "Luiz de Queiroz"(USP).

MATHEWS, R. E. F. Serological techniques for plant viruses. In: MARAMOROSCH, K. \& KOPROWSKI, H., eds. Methods in virology. New York, Academic Press, 1967. vol. 3, p.201-39.

MCCLURE, M. A.; MSAGHI, I.; NIGH. E. L. Shared antigens of parasitic nematodes and hosts plants. Nature, London, 244:306. 1973. 
MENTEN, J. O. M. Morfologia, patogenicidade e serologia de Colletotrichum gloeosporioides f. sp. cucurbitae (Berk. et Mont.) n. comb. e resistência em melancia (Citrullus vulgaris Shrad.) e pepino (Cucumis sativus L.). Piracicaba, 1977. 141p. (Mestrado - Escola Superior de Agricultura "Luiz de Queiroz"/USP).

MOHAN, S. B. Analysis of cross-reactive antigens of Phytophthora fragariae and strawberry and their relation to resistance and suceptibility. J. Phytopathol, Berlin, 127:316-30, 1989.

MORTON. D. J. \& DUKES. P. D. Serological differentiation of race 1 from race 2 of Fusarium oxysporum f. sp. lycopersici. Plant Dis. Rep., St. Paul, 50:444-5,1966.

NOVAK, L. A. \& KOHN. L. M. Developmental proteins in Aspergillus. Exper. Mycology, Duluth. 14:339-50. 1990.

PALMERLEY, R. A. \& CALLOW, J. A. Common antigens in extracts of Phytophthora infestans and potatoes. Physiol. Plant Pathol, London, 12:241-8, 1978.

PATERSON, R.; YOUNGNER, J. S., WEIGLER, W. O.; DIXON, F. J. Antibody production and transfer to egg yolk in chickens. J. Immunology, Baltimore, 89:272$8,1962$.

POLSON, A.; COETZER, T.; KRUGER, J.; VON MALTZAHN, E.; VAN DER MERWE, K. J. Improvements in the isolation of $\mathrm{IgY}$ from the yolks og eggs laid by immunized hens. Immunoi. Invest., New York, 14:323-7, 1985.

POLSON, A.; VON WECHMAR, M. B.; VAN REGENMORTEL, M. H. V. Isolation of viral $\operatorname{IgY}$ antibodies from yolks of immunized hens. Immunol. Commun., New York, 9:475-93. 1980.

PURKAYASTHA, R. P. \& GHOSAL, A. Anatysis of cross-reactive antigens of Accrocylindrium orvzae and rice in relation to sheath rot disease. Physiol. Plant Pathol, London, 27:245-52, 1985. 
RATAJ-GURANOWSKA, M.; WIATROSZAK, I; HORNOK, L. Serological comparison of two races of Fusarium oxvsporum f. sp. lupint. Phvtopath. Z.. Berlin, 110:221-5, 1984.

RICKE, S. C.; SCHAEFER, D. M.; COOK, M. E.; KANG, K. H. Differentiation of ruminal bacterial species by enzyme-linked immunosorbent assay using egg yolk antibodies from immunized chicken hens. Appl. Environ. Microbiol., Washington, 54:596-9, 1988.

SCALA. F. \& CRISTINZIO. G. Common antigens in extracts of pea and Nectria haematococca. In: INTERNATIONAL CONGRESS OF PLANT PATHOLOGY, 5., Tokyo. 1988. Proceedings. Tokyo, International Society for Plant Pathology, 1988. p. 225.

SCHNATHORST, W. C. \& DEVAY, J. E. Common antigens in Xanthomonas malvacearum and Gossypium hirsutum and their possible relationship to host specificity and disease resistance. Phytopathology, St. Paul, 53:1142, 1963. (Resumo).

SHIMIZU, M.; FITZSIMMONS, R. C.; NAKAI, S. Anti-E. coli immunoglobulin Y isolated from egg yolk of immunized chickens as a potential food ingredient. $J$. Food Science, Chicago, 53:1360-6, 1988.

SONG, C.; YU, J.; BAI, D. H.; HESTER, P. Y.; KMM, K. Antibodies to the -subunit of insulin receptor from eggs of immunized hens. $J$. Immunology, Baltimore, 135:3354-9, 1985.

SPIRO, R. G. Study of the carbohydrates of glycoproteins. In: GINSBURG, V., ed. Complex carbohydrates part B. Methods in enzymology. New York, Academic Press, 1972, vol. 28, p.3-43.

THALHAMER, J. \& FRELND, J. Cascade immunization: a method of obtaining polyspecific antisera against crude fractions of antigens. J. Immunol. Meth., Amsterdam. 66:245- 51, 1984. 
TEMPEL, A. Serological studies on Fusarium oxysporum Schl. emend Sn. et H. Nature, London, 180:1483, 1957.

VANDERPLANK, J. E. Host-pathogen interactions in plant disease. New York, Academic Press, 1982. 207p.

VIEIRA, J. G. H.; OLIVEIRA, M. A. D.; MACIEL, R. M. B.; MESQUTTA, C. H.; RUSSO, E. M. K. Development of an homologous radioimmunoassay for the synthetic amino terminal (1-34) fragment of human parathyroid hormone using egg yolk-obtained antibodies. J. Immunoassav, New York. 7:57-72, 1986.

VIEIRA. J. G. H.: OLIVEIRA, M. A. D.: RUSSO, E. M. K.: MACIEL. R. M. B.; PEREIRA. A. B. Egg yolk as a source of antibodies for human parathyroid hormone (hPTH) radioimmunoassay. J. Immunoassay, New York, 5:121-9, 1984.

WIMALAJEEWA, D. L. S. \& DEVAY, J. E. The occurrence and characterization of a common antigen relationship between Ustilago maydis and Zea mays. Physiol. Plant Pahtol., London, 1:523-35, 1971.

WYCOFF, K. L, \& AYERS, A. R. Monoclonal antibodies to surface and extracellular antigens of a fungal plant pathogen, Phytophthora megasperma f. sp. glycinea recognize specific arbohydrate epitopes. Physiol. Mol. Plant Pathol., London, $37: 55-79,1990$.

WYCOFF, K. L.; JELLISON, J.; AYERS, A. R. Monoclonal antibodies to glycoproteins antigens of a fungal plant pathogen, Phytophthora megasperma $\mathrm{f}$. sp. glycinea. Plant Physiol., Lancaster, 85:508-15, 1987. 